UNIVERSIDADE DE BRASÍLIA - UnB

INSTITUTO DE LETRAS - IL

DEPARTAMENTO DE TEORIA LITERÁRIA E LITERATURAS - TEL PROGRAMA DE PÓS-GRADUAÇÃO EM LITERATURA

Tanatografia n'Os Demônios de Dostoiévski:

arena discursiva e suicídio literário de Stavróguin

THAÍS FIGUEIREDO CHAVES

ORIENTADOR: PROF. DR. AUGUSTO RODRIGUES DA SILVA JUNIOR 
THAÍS FIGUEIREDO CHAVES

\title{
Tanatografia n'Os Demônios de Dostoiévski: arena discursiva e suicídio literário de Stavróguin
}

\begin{abstract}
Dissertação apresentada ao Departamento de Teoria Literária e Literaturas do Instituto de Letras da Universidade de Brasília com vistas à obtenção do grau de Mestre em Literatura e Práticas Sociais.
\end{abstract}

Orientador: Prof. Dr. Augusto Rodrigues da Silva Junior 


\section{Tanatografia n'Os Demônios de Dostoiévski: arena discursiva e suicídio literário de Stavróguin}

Dissertação apresentada ao Departamento de Teoria Literária e Literaturas do Instituto de Letras da Universidade de Brasília com vistas à obtenção do grau de Mestre em Literatura e Práticas Sociais.

BANCA EXAMINADORA:

Orientador - Professor Doutor Augusto Rodrigues da Silva Junior Programa de Pós-Graduação em Literatura, UnB

Eclair Antônio de Almeida Filho

Programa de Pós-Graduação em Tradução, LET/UnB

Erivelto da Rocha Carvalho

Programa de Pós-Graduação em Literatura, UnB

Anderson Luís Nunes da Mata

(Suplente)

Programa de Pós-Graduação em Literatura, UnB

Brasília-DF, 07 de julho de 2015 
Para Cláudia e Ademar,

com amor. 


\section{AGRADECIMENTOS}

Aos meus pais, pelo amor incondicional e pela paciência infinita. Por toda a dedicação, por todos os sacrifícios feitos e pela convivência amorosa capaz de descansar todo o cansaço mental e físico. Obrigada por sempre estarem dispostos a me socorrer e por terem colocado, tantas vezes, a minha felicidade em primeiro lugar.

A Paulo Paniago, que esteve presente em todos os momentos desse sonho literário. Pelo companheirismo e pelo ombro firme nas horas de tristeza. Por ter sido minha rota de fuga nos momentos de crise e meu companheiro de viagem nesta grande trajetória. Pela inspiração sem fim e pela disposição em alimentar o sonho.

Ao meu orientador, Augusto Rodrigues, por ter confiado em mim, por todo incentivo e pelo aprendizado de valor incomensurável dos últimos anos. Este trabalho não teria nascido sem a leitura cuidadosa, as aulas preparadas com carinho e toda atenção dedicada e guerreira de um verdadeiro mestre.

A Anderson da Mata, por nunca ter deixado de me incentivar pelos corredores da universidade e pela constante crença na minha capacidade de conduzir uma carreira

intelectual. À inspiração que me acompanha desde o começo da caminhada: muito obrigado!

Aos amigos-irmãos que foram a minha verdadeira rocha de sustentação: Cibele Kamchen, Tiago Amate, Jéssica Vasconcelos. Perto ou longe, nunca deixaram de ser minha verdadeira referência de confiança e amor. Obrigada por nunca terem deixado de torcer por mim, mesmo nos momentos mais difíceis.

A Kellma Simplício, Pedro Couto, Ariadne Coelho, Lemuel Gandara, Ana Clara Medeiros, Stephanie Winkler, Elizabete Barros, Marcos Sugizaki e Bruna Ferreira. Por todos os conselhos, risadas, pelo aprendizado mútuo e pela honra de ter contado com esta importante rede de apoio na universidade.

A Paulo Renato Souza Cunha e Marianna Rios, que nunca deixaram o sonho russo se apagar em mim e por todo o companheirismo literário. A minha chefe, Thaís Bicalho, por toda a paciência e compreensão. Pelo apoio e pela preocupação sincera com o meu percurso acadêmico. 
O inferno dos vivos não é algo que será; se existe, é aquele que já está aqui, o inferno no qual vivemos todos os dias, que formamos estando juntos. Existem duas maneiras de não sofrer. A primeira é fácil para a maioria das pessoas: aceitar o inferno e tornar-se parte deste até o ponto de deixar de percebê-lo. A segunda é arriscada e exige atenção e aprendizagem contínuas: procurar e reconhecer quem e o que, no meio do inferno, não é inferno, e preservá-lo, e abrir espaço.

Italo Calvino, As cidades invisíveis 


\section{RESUMO}

Após as Reformas Gerais, em 1861, na Rússia, que libertaram os servos e criaram uma atmosfera propícia para o capitalismo, o país se viu em um período de transição. As mudanças sociais geraram uma onda de suicídios. O tema gerou grande preocupação em Fiódor Dostoiévski e foi amplamente abordado pela obra do autor, principalmente no romance Os demônios [1871]. O trabalho se propõe a analisar como a indecidibilidade, o posicionamento diante da existência de Deus, a polifonia interna dos personagens e a estilização da voz narrativa a partir de ângulos dialógicos dos discursos são importantes para a manutenção ou a extinção da vida. Neste sentido, a tanatografia, n'Os demônios de Dostoiévski, habita uma arena discursiva cujo suicídio - estilizado e vivo - literário instaura-se nas relações de alteridade.

Palavras-chave: Dostoiévski, Bakhtin, tanatografia, suicídio, polifonia 


\begin{abstract}
After the Great Reforms, in 1861, in Rússia, the political event that freed the serfs and originated a propitious atmosphere for capitalism, the country was imersed in a transition period. The social changes created a suicidal wave. The theme was one of Fyodor Dostoevski's mains concerns and it was broadly discussed in his works, mainly in The Devils [1871]. The present text offers an analysis of how the inability to decide, the failure to position about the question of God's existence, the internal poliphony of the characters and the estilization of the narrative voices from dialogical angles of the discourse are important for the maintenance or extinction of life. In this sense, the tanatographie, in Dostoevsky's Demons, inhabits a discursive arena in which literary suicide - stylized and alive - is established in the relations of otherness.
\end{abstract}

Keywords: Dostoevsky, Bakhtin, tanatography, suicide, poliphony 


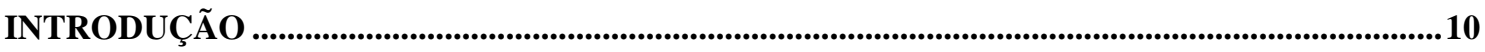

PARTE I - DIANTE DA ARENA DISCURSIVA: QUESTÕES TEÓRICAS .....................................13

CAPÍTULO 1: OUTRA VIAGEM: DO MUNDO DOS MORTOS AO INFERNO DOS VIVOS ....14

1.1. QUESTÕES DE GÊNERO LITERÁRIO......................................................................................... 14

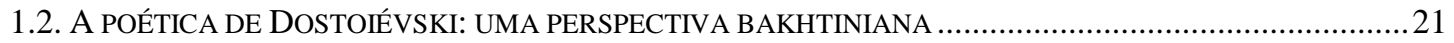

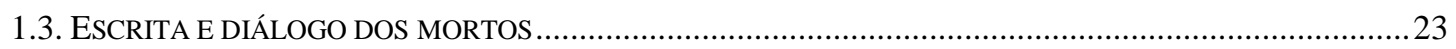

CAPÍTULO 2: MÃOS VIOLENTAS: A QUESTÃO DO SUICÍDIO ..................................................30

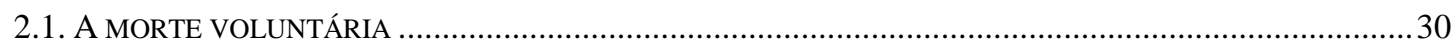

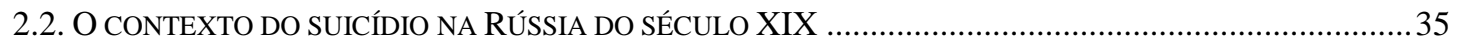

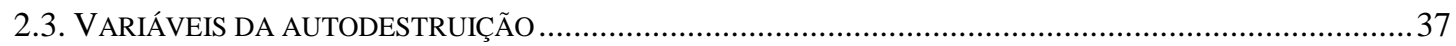

2.4. O ATO EXTREMO: SUICÍDIO EM OS DEMÔNIOS ............................................................................. 42

PARTE II - SUICÍDIO LITERÁRIO .............................................................................................45

CAPÍTULO 3: DIÁLOGOS DE MORTE EM OS DEMÔNIOS: A ARENA INFERNAL DE

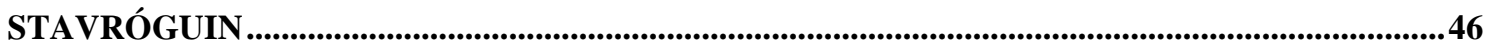

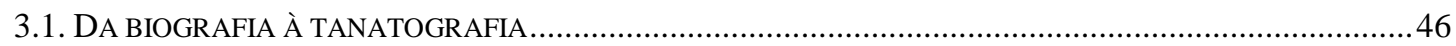

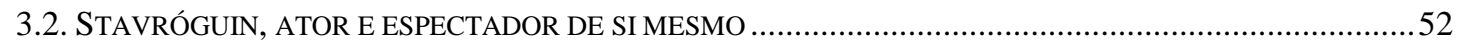

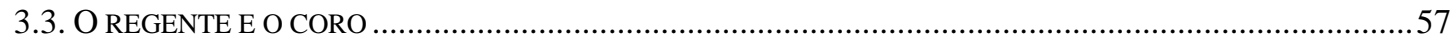

CAPÍTULO 4: DIALOGISMO DA AUTODESTRUIÇÃO: TRÊS VOZES DISSONANTES ..........68

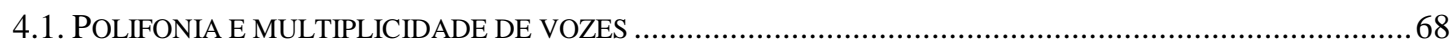

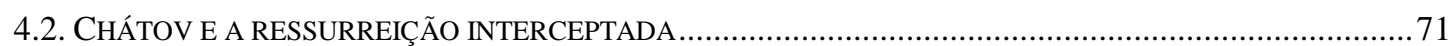

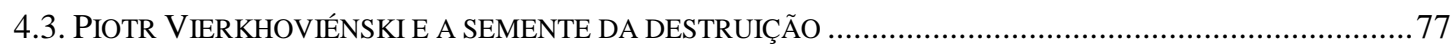

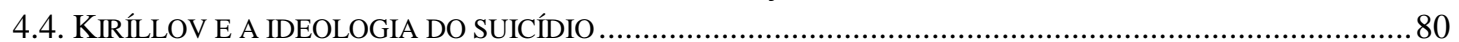

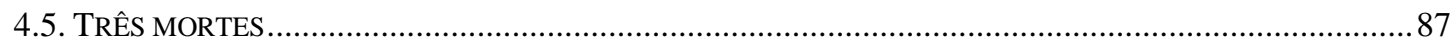

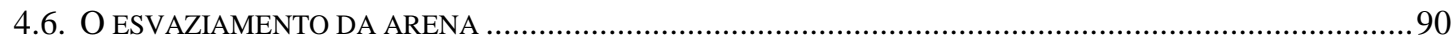

CAPÍTULO 5: LETRAS DA MORTE ................................................................................................91

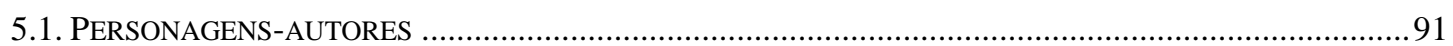

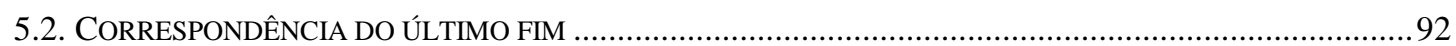

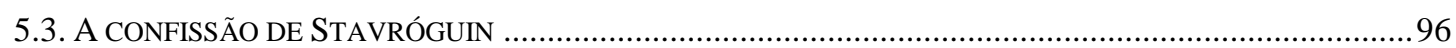

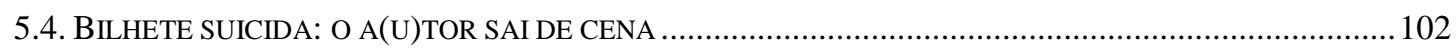

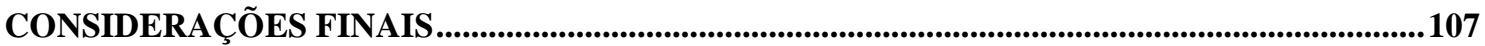

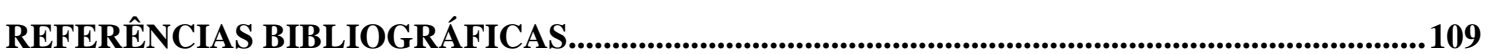




\section{INTRODUÇÃO}

Fiódor Mikháilovitch Dostoiévski (1821-1881) é um dos nomes mais importantes da literatura mundial. Segundo o crítico literário Mikhail Bakhtin, o escritor foi responsável pela criação de um tipo de romance: o polifônico. Trata-se de um método narrativo no qual a visão do autor não se funde com a dos personagens, cujo resultado é o retrato de homens autônomos em constante processo de autorreflexão. Os heróis dostoievskianos são dotados de liberdade. São sujeitos ideólogos: a fala de um nunca perde de vista a resposta do outro, num processo conhecido como dialógico.

A polifonia como método permitiu um modo riquíssimo de interação entre os personagens, no qual o autor dá autonomia para os personagens e eles nunca perdem de vista o fato de que são produtores do discurso que enunciam. A polifonia, porém, é mais que a exposição em sequência de pontos de vistas que diferem entre si. Trata-se da construção de um coro em que a ficção reconhece a si mesma como produto da realidade e criadora de uma realidade.

Antonio Candido (2010) identifica nessa forma de expressão uma linha realista, cujos substratos são reproduzidos a partir da realidade. Lugares, pessoas e situações são reconhecíveis historicamente por informações contidas no texto. Nesse sentido, o mote para Os demônios foi um crime: um jovem foi morto por um grupo radical. Os personagens são inspirados nos modelos iniciais, mas se engrandeceram ao serem estilizados ficcionalmente, pois a literatura permite que questões humanas sejam tratadas de forma mais aprofundada. Segundo Antonio Candido (2010), o texto de ficção cria arranjos ficcionais a partir do mundo, mas também está inserido no mundo, o que permite que os conteúdos dialoguem, interpretem a realidade e produzam efeitos reais. O teórico chamou de redução estrutural o artifício pelo qual, por meio da escrita, as coisas e seres se transformam em narrativas, em composições que podem ser estudadas de forma independente. O estudioso concluiu que os textos literários se tornam mais convincentes à medida em que são mais bem organizados organicamente, em que assumem propriedades fantasiosas e criativas.

Ainda sobre a questão da relação da obra com o mundo, em Os demônios a polifonia e o dialogismo regem o texto. Além de envolver os personagens em seu canto mirífico, o enredo traz à tona elementos como: literatura, política, religião e a história viva presenciada por Dostoiévski na Rússia do século XIX. No âmbito da forma e 
estrutura, o narrador muitas vezes ambíguo e as intenções panfletárias iniciais do autor fornecem uma complexa relação entre o acabamento estético das pessoas e o inacabamento romanesco - de pessoas. No âmbito da publicação, o fatiamento de parte essencial do romance pela censura da época contrapõe o romance que Dostoiévski escreveu ao texto que foi levado ao público no século XIX.

O romance foi publicado na revista $O$ Mensageiro Russo, em 1872. A versão em livro foi lançada no ano seguinte, com direito a nova revisão que eliminava vestígios do encontro de Stavróguin com Tíkhon. O capítulo foi localizado em 1921, junto a anotações de Dostoiévski, e publicado no ano seguinte. Foi objeto de grande polêmica literária. Para Joseph Frank, biógrafo do autor, os vários trechos censurados e a confissão (publicada em edição brasileira, da editora 34, utilizada neste trabalho), devem ser levados em consideração em análises atuais do livro, decisão adotada por este trabalho. De toda forma, devido às inúmeras alterações inesperadas impostas pelos editores, o texto final do romance não correspondeu aos anseios literários do criador. $\mathrm{O}$ fragmento foi publicado junto ao resto do texto apenas depois da morte do autor.

No âmbito interno, foco desse trabalho, analisar-se-á como as interações dialógicas e polifônicas mantidas pelo protagonista de Os demônios desencadeiam o seu fim trágico. Ao levantar as mais variadas questões metafísicas e envolver várias outras pessoas em suas dúvidas e questionamentos, ele exerce uma influência maligna geral, como um Mefistófeles diante de inúmeros Faustos. Stavróguin foi um agitador de sepulturas na medida em que seu poder de influência causou a destruição de um número significativo de pessoas. Um guia espiritual para o inferno dos vivos, experiência que significa ausência de esperança de viver e no destino após a morte.

O primeiro capítulo da presente análise fornece esclarecimentos sobre o gênero romance, no qual Os demônios está inserido. A perspectiva parte essencialmente das considerações de Mikhail Bakhtin, eleito como pilar teórico deste trabalho. É nesse ponto do trabalho que as noções de arena discursiva, dialogismo, personagens ideólogos e inferno no romance de Dostoiévski serão explicadas. Há panoramas de personagens que desceram ao mundo dos mortos e continuaram discursando como contraponto à voz demoníaca que arrasta o mundo para o abismo.

No segundo capítulo, um panorama histórico sobre a questão da morte voluntária e do autoaniquilamento. O presente trabalho parte do ponto de vista que a autodestruição dos heróis dostoievskianos é geralmente um processo e, para isso, recupera exemplos de situações em que isso ocorre, mesmo que a morte não seja 
retratada. Por fim, o suicídio é apresentado como tema de força na obra do autor e questão crucial em Os demônios.

O terceiro capítulo está focado nas influências destrutivas que um personagem exerce sobre o outro, o que encaminha a trama para um destino caótico. No centro da torre de Babel niilista, está Nikolai Stavróguin, dotado de elementos trágicos e contaminado pelo mal du siècle. O foco analítico é a morte do sujeito sobre o ponto de vista do outro, bem como o poder do discurso de sobreviver àquele que o proferiu. Escrita e diálogos de morte como forma de exteriorizar questões internas numa escrita de morte - tanatografia - coletiva.

O quarto capítulo diz respeito aos elementos da arena discursiva instaurada pelo protagonista de Os demônios com três personagens principais: Chátov, Kírillov e Vierkhoviénski. Melancólico e entendiado, o homem aristocrático influenciava pessoas e abandonava discursos, sem conseguir adotar nenhuma convicção verdadeira. Cada un dos jovens olhava para ele como a um falso deus, atitude que teve resultados funestos. Um foi assassinado, outro se suicidou e o terceiro cometeu assassinato.

O quinto capítulo trata do suicídio de Stavróguin, que ocorreu quando todo o círculo ao seu redor já havia sido consumido pelas chamas de seu inferno pessoal. Inferno de várias vozes. São analisados documentos escritos pela personagem, nos quais ele estiliza os maiores problemas e questionamentos internos, principalmente no que diz respeito à questão da existência de Deus. A forma em que o narrador descreve essa morte tão emblemática também é foco de análise.

A polifonia dissonante e caótica em torno da "Arena de Stavróguin" (DOSTOIÉVSKI, 2004, p. 494), termo usado pelo narrador de Os demônios para mencionar as pessoas que conviviam com a personagem principal, pavimentou o caminho para o suicídio dele. Ao agir como mediador de um diálogo infernal, em vez de harmonizar o conjunto, o homem só conseguiu provocar o caos, a adoração a falsos deuses e a destruição generalizada. O suicídio de Stavróguin é fruto do fracasso religioso, social, político e psicológico. Ou seja, explica muito mais a vida que a morte da personagem - elemento que Bakhtin contrapõe a Tolstói: Dostoiévski sempre representa a morte, em todas suas tanatografias, em relação de alteridade. A morte é sempre vivenciada pelo outro e não pelo ser que morre. A presente análise se propõe a pensar o tema da morte, principalmente por meio do protagonista de Os demônios, por meio da vida, das crises e reviravoltas e do limiar, da capacidade do discurso de aproximar a existência na Terra a um céu ou a um inferno. 


\section{PARTE I}

DIANTE DA ARENA DISCURSIVA:

QUESTÕES TEÓRICAS 


\title{
CAPÍTULO 1: OUTRA VIAGEM: DO MUNDO DOS MORTOS AO INFERNO DOS VIVOS
}

\author{
O filho do Rei, Ferdinando, cabelo em pé \\ (mais parecia junco que uma cabeleira), \\ foi o primeiro a jogar-se ao mar; gritou \\ "O inferno está vazio, todos os demônios estão aqui." \\ William Shakespeare, A tempestade
}

\subsection{Questões de gênero literário}

Em 1859, após um período de prisão e exílio, Dostoiévski retornou a São Petersburgo. Recém-convertido à ortodoxia, o escritor passou a enxergar o mundo sob uma perspectiva mais espiritual, transformação que deixou marcas em seus escritos. $O$ trabalho jornalístico produzido no período pós-siberiano concentrou-se na polêmica com os niilistas. A prosa literária ampliou essas discussões por meio de arenas discursivas e romanescas. Desde a morte de Dostoiévski até a atualidade, a crítica literária se interessou pela tendência anti-radical de sua obra. Richard Freeborn (1992, p. 323), no artigo "The Nineteenth Century: The Age of Realism, 1855-80", descreve o romance Os demônios como a anatomia da intelligentsia russa do começo dos anos 1870. Ele explica (1992, p. 330) que a disposição de Dostoiévski para polemizar com os problemas da atualidade condizia com o período - considerado o auge do realismo russo - compreendido entre os anos 1850 e começo dos anos 1870. A literatura realista olhava para o futuro enquanto mantinha os pés firmemente apoiados no presente.

Segundo Ellen Chances (2001), no artigo “The Superfluous Man in Russian Literature", Os demônios descreve uma Rússia que havia se desligado dos valores do povo. O romance retrata como os personagens foram possuídos por ideias europeias e afastados das raízes nacionais e ortodoxas. Para ela, a Rússia ocidentalizada seria frívola. Destaca que Stavróguin, Vierkhoviénski e Stiepan Trofímovitch estão perdidos nesta conjuntura. Ao fim do enredo, o velho é o único que encontra algum tipo de salvação, por meio do contato com o "solo" nativo e com a aproximação com o cristianismo. Para Louis Breger (1989), no livro Dostoevsky: The Author as Psychoanalyst, os radicais do romance, enquanto se envolvem em discussões ideológicas e esquemas revolucionários, são retratados como grupo problemático. Não conseguem nem concordar uns com os outros, nem melhorar a sociedade. 
Segundo o pesquisador brasileiro Bruno Gomide (2011), a questão do niilismo despertou curiosidade fora da Rússia. Em 1881, quando Alexandre II, o tzar que concedeu liberdade aos servos, foi assassinado, o assunto ganhou destaque na imprensa brasileira. Os jornais publicaram matérias sobre julgamentos e execuções associadas aos niilistas radicais. A popularidade do tema aumentou o interesse pela literatura russa em terras nacionais: "Era inevitável que tais impressões fossem, com o tempo, assimiladas à crítica e ao ensaio feitos sobre o romance russo, especialmente por uma tradição crítica como a brasileira, tão afeita ao romance hugoano" (GOMIDE, 2011, p. 56).

Em 1886, com a publicação de $O$ romance russo, de Melchior de Vogüé, na França, a crítica mundial interessada em literatura russa ganhou uma primeira referência de peso. Trata-se de um "dos acontecimentos mais bem documentados da historiografia literária. Entre 1883 e 1886 os russos surgem como tema intelectual e fenômeno editorial" (GOMIDE, 2011, p. 83). Apesar de Os Demônios não ser o tema da crítica, a angústia associada a temas espirituais, que podem levar ao fim, já está bem marcada no capítulo dedicado a Dostoiévski, o que fica claro pela escolha do título: "A religião do sofrimento". O estudioso francês escreveu sobre a conversa de Crime e castigo, na qual Raskólnikov diz à Sônia ter matado a velha usurária, o que já apontava para a confissão como elemento primordial de composição literária dostoievskiano.

A investida de Vogüé permitiu que autores brasileiros analisassem a obra do escritor russo. Em “Sempre Dostoiévski”, Augusto Meyer diz que os grandes livros do autor são mais que um esforço folhetinesco bem-sucedido: "Ultrapassam as intenções puramente literárias, fundindo-se no plano das grandes angústias metafísicas" (MEYER, 2007, p. 111). Segundo o crítico, o autor adota uma forma democrática de narrativa, na qual ele não julga os próprios personagens. Para ele, o russo criou homens espiritualmente complexos cujas ações não podem ser previstas. Sobre Os demônios, afirma que o escritor "traça um quadro profético da grande revolução. Fabulando, chegou quase a prever o destino do seu povo" (MEYER, 2007, p. 120). A afirmação do crítico se deve ao fato de o romance trabalhar com temas que marcariam a história russa do século XX russo, tais como socialismo e revolução.

O pressuposto da trama do romance Os demônios é o de uma sociedade revolucionária e secreta cujo objetivo seria devastar as estruturas de poder e implantar o caos na Rússia do século XIX. Quando surge a suspeita de que um dos membros estaria disposto a delatar os demais, ele é assassinado. O enredo é parcialmente inspirado em 
um crime cometido na época, no qual o estudante Ivan Ivánov foi morto por revolucionários chefiados por Serguiei Netcháiev:

\begin{abstract}
O que ocorre n'Os demônios é mito e não história (tomando a palavra mito no sentido de ampliação imaginária do real), arte e não verdade literal [...]. N'Os demônios o autor apenas dá vida artística àquilo que já encontrou inscrito nos documentos que tinha à disposição (FRANK, 2003, p. 572).
\end{abstract}

Escrito entre os anos de 1871-1872, o romance foi fruto de um laborioso trabalho de pesquisa. $\mathrm{O}$ autor leu atentamente as polêmicas divulgadas pela imprensa envolvendo a questão revolucionária e radical da Rússia oitocentista. Criou um enredo que traça um quadro crítico da geração em que viveu, uma época de avanços científicos e declínio das crenças religiosas. Para Dostoiévski, os revolucionários ateus e a aristocracia haviam se afastado do modo de viver da Rússia ao tomar o Ocidente como inspiração política, social e cultural. Partiu de um caso em particular para discutir a questão do niilismo como problema nacional e universal.

No posfácio da edição brasileira de Os demônios, utilizada neste trabalho, o tradutor Paulo Bezerra afirma que, no texto, "Dostoiévski revela sua sensibilidade excepcional para as vicissitudes da história, o seu sentido dialético, assim como a dialética da alma do ser humano como entidade enraizada na história alimentada por ela” (BEZERRA, 2004, p. 693). Para o especialista, Os demônios não apenas foi o primeiro romance sobre o terrorismo, como conseguiu antecipar os horrores do totalitarismo ocorridos nos séculos XX e XXI. Para ele, o autor demonstrou sagacidade para antecipar as tendências políticas da história: "É espantosa a atualidade de $O s$ demônios" (BEZERRA, 2004, p. 697). Classifica-o como um "romance-profecia".

A força premonitória de $O s$ demônios pode ser explicada parcialmente pelo gênero em que se insere. Segundo Mikhail Bakhtin (2010b, p. 422), “o romance pode servir como documento para a previsão dos grandes destinos, ainda longínquos, da evolução literária". Ainda sobre o modo de ser romanesco, explica que ele "quer profetizar os fatos, predizer e influenciar o futuro real, o futuro do autor e dos leitores [...] seus traços são a reinterpretação e a reavaliação permanentes" (BAKHTIN, 2010b, p. 420). Para o pensador russo, o caráter fluido e antecipatório do romance está relacionado à sua capacidade de autorreflexão. Além disso, uma das maneiras de o gênero concretizar propriedades metalinguísticas é por meio da paródia - mesmo que seja a paródia séria, como no romance suicidário. Dostoiévski transformou a paródia do radicalismo em tema do romance Os demônios. O teórico russo (2010b) explica que 
paródia é uma via de mão dupla, pois se refere tanto ao objeto daquilo que se fala, como à palavra de outrem, sendo que ambos os aspectos da linguagem têm consciência um do outro. A linguagem do outro é apropriada, mas com objetivo e significado diferentes dos utilizados inicialmente, há aterrissagem do conceito inicial. As vozes são colocadas juntas, mas estão em conflito. Segundo Bakhtin, “as estilizações paródicas dos gêneros diretos e dos estilos ocupam lugar essencial no romance" (BAKHTIN, 2010b, p. 399).

No ensaio teórico "Epos e romance", Mikhail Bakhtin (2010b) parte da Grécia antiga para lançar luz sobre particularidades do gênero literário. O estudo é importante, pois apesar das complexidades envolvendo a composição de Os demônios, seja pelo fatiamento do texto pela censura ou as intenções panfletárias (iniciais) que motivaram o autor, deve-se pensá-lo no interior do próprio gênero romanesco. O crítico apresenta uma diferença principal entre o romance e outras formas narrativas: não tem um modelo com regras internas definidas e a plasticidade constitui uma de suas principais particularidades. Para descrever o surgimento do romance, Bakhtin realiza comparação deste com a epopeia. O teórico (2010b, p. 405) localiza o gênero mais antigo como aquele dotado de forma enrijecida. Autores de epopeia divulgavam um passado remoto, em posição de isolamento em relação ao presente e ao futuro, pois já estava terminantemente finalizado. O mundo épico não podia ser modificado, nem sofrer inferências criativas ao ser descrito, pois tinha foco na memória. A contemporaneidade não era representada na epopeia, que se baseava em uma lenda, "sagrada e peremptória, que envolve uma apreciação universal e exige uma atitude de reverência para consigo" (BAKHTIN, 2010b, p. 408). Nos gêneros clássicos, o homem era representado de forma distanciada, de modo fechado e absoluto, ou seja, sempre coincidia consigo mesmo. A concepção de mundo do herói é a mesma do autor e atendia a uma classe específica no ato da performance ou na escrita - como no exemplo de Homero.

Segundo Bakhtin (2010b), o romance nasceu da reestruturação e parodização dos gêneros elevados. Foi apenas por meio de um processo da familiarização entre gêneros, que passou pela absorção do riso e de elementos folclóricos e populares, que a literatura passou a retratar o mundo de forma mais livre - daí as raízes da ideia de arena discursiva. A representação não dava mais conta de todo o homem, que agora figurava como em constante conflito com a própria vida. Sobre o gênero novo, o teórico afirma:

A primeira peculiaridade de todos os gêneros do sério-cômico é o novo tratamento que eles dão à realidade. A atualidade viva, inclusive o dia a dia, é objeto ou, o que é ainda mais importante, o ponto de partida da interpretação, apreciação e formalização da realidade. [...] Nesses gêneros, os heróis míticos 
e as personalidades históricas do passado são deliberada e acentuadamente atualizados, falam e atuam na zona de um contato familiar com a atualidade inacabada (BAKHTIN, 2010b, p. 122-123).

Ainda sobre as questões de antecedência, Bakhtin explica: "Pode-se dizer que o gênero romanesco se assenta em três raízes básicas, a épica, a retórica e a carnavalesca" (BAKHTIN, 2010a, p. 124). Para Bezerra (2010, p. 8), o teórico russo não ignora outras formas primitivas do romance, mas destaca que a tradição do sériocômico chegou a Dostoiévski com mais força. O estudioso destaca que em Mimesis, Erich Auerbach também apontou a origem do romance no contexto greco-latino. O teórico russo destaca dois gêneros emblemáticos dessa linhagem: os diálogos socráticos e a sátira menipeia. O primeiro surgiu na Antiguidade clássica. Escrito em forma dialogal, com marcas prosaicas, apresentava forte relação com o cotidiano. Tinha como figura central uma pessoa que conversava. Possuía dois métodos principais, a síncrise e a anácrise, que consistiam na exposição de vários pontos de vista sobre um assunto e na provocação da "palavra pela própria palavra, e não pela situação de enredo" (BAKHTIN, 2010a, p. 126). Os participantes do diálogo socrático eram ideológicos e tinham como fim a busca da verdade na arena discursiva instaurada por Sócrates.

Segundo o pesquisador russo (2010a), a sátira menipeia foi denominada como gênero no século I a.C. Influenciou as literaturas cristã antiga e bizantina, ou seja, teve ressonância nos escritos da Rússia antiga. Consiste em um gênero dotado de elemento cômico, no qual não há compromisso com a verossimilhança. Trabalha com o exagero, coloca a filosofia em teste em ambientes contrastantes pouco nobres. Versa sobre realidades periféricas, situações psicológicas anormais. Trabalha com cenas de escândalo, faz jogo de oxímoros (imperador convertido em escravo etc.) e utiliza-se do maravilhoso-experimental no enredo, ou seja, coisas fantásticas acontecem "naturalmente". A característica principal da menipeia, utilizada aqui como aporte para a sustentação teórica de que o romance $O s$ demônios é uma arena discursiva, relacionase com a sua ilimitada liberdade quanto ao desenvolvimento do enredo e da experimentação filosófica: “A particularidade mais importante do gênero consiste em que a fantasia mais audaciosa e descomedida e a aventura são interiormente motivadas, justificadas e focalizadas aqui pelo fim puramente filosófico-ideológico [...]" (BAKHTIN, 2010a, p. 130). O fato de que os protagonistas das histórias eram figuras históricas ou retiradas das lendas não obstruía a intenção do gênero: testar ideias. 
A tendência à experimentação filosófica está calcada na personalidade multifacetada de Stavróguin. Pode ser entendida como indicativo da influência das sátiras menipeias na obra de Dostoiévski. Conhecido pelo constante envolvimento em confusões violentas e casos sexuais múltiplos, o protagonista de Os demônios é a personificação de oxímoros, síntese de extremos e convergência de dissonâncias. Isso pode ser esclarecido na descrição física apresentada pelo narrador. Cabelos negros/olhos claros; cor do rosto suave salpicada por um corado "demasiadamente vivo"; dentes pérolas/lábios corais; forte, porém baixo; modesto/ousado; elegante, mas sem requinte; seguro de si, sem ser loquaz; aparência-máscara/personalidade-fera. Stavróguin é um homem cuja aparência não revela muito sobre a sua personalidade, cujas ações abrigam sempre uma dissimulação: "Parecia ter a beleza de uma pintura, mas, ao mesmo tempo, tinha qualquer coisa de repugnante" (DOSTOIÉVSKI, 2004, p. 52).

Encontramos nele também os seguintes traços da menipeia: “A representação de inusitados psicológico-morais anormais do homem - toda espécie de loucura ('temática maníaca'), da dupla personalidade, do devaneio incontido, de sonhos extraordinários, de paixões limítrofes com a loucura" (BAKHTIN, 1997, p. 116). Também se percebem elementos como a decadência do imperador em escravo (de importante membro da infantaria passa a soldado, ou seja, há também na trajetória da personagem um componente de decadência); queda moral e a purificação (Stavróguin viola sexualmente uma menina e escreve um documento confessando o crime, numa tentativa de redenção); o luxo e a miséria ("passava dias e noites em favelas escuras e sabe Deus em que vielas, tornara-se desleixado, andava esfarrapado"); era um bandido nobre (conhecido por ter matado duas pessoas em duelo e por ter sido entregue à justiça). Ainda sobre a menipeia, Bakhtin discorre que o gênero "gosta de jogar com passagens e mudanças bruscas, o alto e o baixo, ascensões e decadências, aproximações inesperadas do distante e separado, com toda sorte de casamentos desiguais" (BAKHTIN, 1997, p. 118). Vale lembrar que a personagem se tornou marido da coxa Mária Lebiádkina pois achou, a princípio, que a união inusitada lhe seria maior tormento que o suicídio.

Essa multiplicidade de facetas e nuances psicológicas seria impossível na representação greco-romana clássica. Segundo o teórico russo (2010b, p. 423), os homens épicos eram figuras dotadas de perfeição, porém, estavam plenamente acabadas: "Seu ponto de vista sobre si mesmo coincide plenamente com o ponto de vista dos outros sobre ele [...] Aquilo que se representa coincide com aquilo que é representado". A liberdade introduzida pelos elementos cômicos possibilitou a 
exploração das possibilidades e discrepâncias entre a aparência exterior e a vida cotidiana: "O homem deixou de coincidir consigo mesmo e, portanto, o enredo deixou de revelar o homem por inteiro" (BAKHTIN, 2010b, p. 424).

Uma das características do gênero romance é que ele não trata da figura do herói, mas da personagem. Trata-se de um ser em constante evolução, passível de amadurecimento e transformações pessoais. O novo modo literário se concentrou, frequentemente, no tema da inadequação de uma pessoa para a situação em que se encontra, o que transformaria a subjetividade em tema passível de representação. Assim como os homens representados, o romance também é inacabado. Segundo o teórico russo (2010b), por se tratar de um gênero em construção, ele reflete melhor sobre a realidade, sobre si mesmo e pensa no presente mesmo quando trata do passado. É todo baseado na ideia de experiência e representa um mundo de incertezas absolutas.

Segundo Bakhtin (2010b, p. 426), "o homem adquire no romance uma iniciativa ideológica e linguística que modifica a sua figura (um tipo novo e superior de individualização do personagem). [...] O personagem de romance, como regra, é um ideólogo em maior ou menor grau". A exemplo do que ocorria na sátira menipeia, a ideia possui um lugar importante na obra dostoievskiana. O método de escrita do russo as representa sem que haja fusão com o pensamento do autor. Os grandes romances são protagonizados por homens de ideia, em polêmicas discursivas que debatem as questões urgentes das existências. Estão no mundo e nos livros para tentar chegar a uma resolução: "É nessa solução da ideia que reside toda a vida autêntica e a falta de acabamento dessas personagens. Separadas da ideia em que vivem, sua imagem será totalmente destruída. Separadas da ideia em que vivem, sua imagem será totalmente destruída" (BAKHTIN, 2010a, p. 97). Fora da arena, portanto, perdem o sentido autoconsciente da própria humanidade.

O título deste capítulo refere-se ao encontro entre Dante e Virgílio, quando este informa ao poeta vivo que, para sair da selva escura em que se encontravam, precisariam atravessar o Inferno e o Purgatório. Ao fim da jornada, chegariam ao Paraíso e encontrariam almas mais dignas (Beatriz). "A ti convém seguir outra viagem",/ tornou-me ele ao me ver lacrimejando,/ para escapar deste lugar selvagem [...]" (ALIGHIERI, 2009, p. 37).

Os demônios, por sua vez, não encontram redenção. 


\subsection{A poética de Dostoiévski: uma perspectiva bakhtiniana}

O portador da voz na obra dostoievskiana é o ideólogo. Nos romances, as grandes ideias são sempre personalizadas, mesmo que surjam coletivamente. A personagem é uma ideia viva: consciente do próprio discurso e propagadora de sistemas de crenças. Segundo Bakhtin (2010a), para Dostoiévski, não interessa tanto o que o mundo pensa sobre a personagem, mas o processo que ela vive para descobrir o que significa para si mesma. Dostoiévski faz com que o homem se contemple no espelho e escreve sobre o resultado da autorreflexão. A realidade é importante para retratar a autoconsciência, pois o universo do indivíduo é estruturado de acordo com o que ele acredita. Segundo Bakhtin (2010a, p. 87), o "discurso sobre o mundo se funde com o discurso confessional sobre si mesmo. A verdade sobre o mundo, segundo Dostoiévski, é inseparável da verdade do indivíduo”. No mesmo sentido, Luigi Pareyson (2012, p. 28) diz que os romances do escritor russo são repletos de "princípios viventes".

A composição das personagens é complexa: sabem que são objeto de observação alheia e opiniões se cruzam no cotidiano. Os heróis tentam antecipar considerações sobre eles e, por estarem cientes do julgamento externo, mantêm traços de inacabamento. As reações ao outro tentam responder antecipadamente a possíveis perguntas. Dois exemplos: O homem de Memórias do subsolo [1864], que se ofende para tornar sem impacto qualquer julgamento, bem como alimentar seu senso de importância pessoal. "Compreendo muito bem que se possa às vezes, apenas por vaidade, até urdir crimes a respeito de si mesmo, e percebo muito bem de que tipo essa vaidade pode ser" (DOSTOIÉVSKI, 2000, p. 53). Outro exemplo é quando, em Crime e castigo [1866], a mãe de Raskólnikov envia a ele uma carta para comunicar o noivado da filha. A carta contém argumentações a contestações que ele não havia feito, mas que ela sabia que surgiriam assim que o rapaz se informasse da novidade.

Segundo Bakhtin (2010a, p. 31), "a categoria fundamental da visão artística de Dostoiévski não é a formação, mas a coexistência e a interação". A estilização é dialógica: a linguagem de uma personagem é analisada do ponto de vista alheio. Bakhtin explica que, em Dostoiévski, "a ideia é interindividual e intersubjetiva, a esfera da sua existência não é a consciência individual, mas a comunicação dialogada entre as consciências" (BAKHTIN, 2010a, p. 98). Para Bezerra, o cerne da contribuição bakhtiniana a respeito de Dostoiévski é a identificação da "presença das palavras de uma personagem abrindo fissuras na consciência da outra"; a polifonia como "método 
discursivo do universo aberto em formação"; "o inacabamento como visão do mundo em formação e do homem em formação" e "o ativismo especial do autor no romance polifônico, no qual o autor é a consciência das consciências, a despeito de seu distanciamento em relação ao universo representado e da grande liberdade que concede às suas personagens" (BEZERRA, 2010, p. 6). O inacabamento, além das interações e fissuras entre consciências, caracterizam o que este trabalho chama de arena discursiva:

\begin{abstract}
A ideia não vive apenas na consciência individual isolada de um homem: mantendo-se apenas nessa consciência, ela degenera e morre. Somente quando contrai relações dialógicas essenciais com as ideias dos outros é que a ideia começa a ter vida, isto é, a formar-se, desenvolver-se, a encontrar e renovar sua expressão verbal, a gerar novas ideias. O pensamento humano só se torna pensamento autêntico, isto é, ideia, sob as condições de um contato vivo com o pensamento dos outros, materializado na voz dos outros, ou seja, na consciência dos outros expressa na palavra. É no ponto desse contato entre vozes-consciências que nasce e vive a ideia (BAKHTIN, 2002, p. 86).
\end{abstract}

$\mathrm{Na}$ poética do autor, a ideia é representada como um "acontecimento vivo" (BAKHTIN, 2010a, p. 98), nasce no contato entre as consciências. O discurso de um personagem é transformado por causa do contato com o outro. "Cada ideia dos heróis de Dostoiévski sugere, desde o início, uma réplica de um diálogo não concluído" (BAKHTIN, 2010a, p. 36). O seu método de escrita é composto pela multiplicidade de vozes, porém, é necessário que não haja assimilação completa do discurso alheio, caso contrário, não há dialogismo. Em Os demônios, por exemplo, toda assimilação é deturpação e reinterpretação, mesmo quando a recepção se dá no nível mais íntimo e subjetivo de uma personagem (Chátov e Kiríllov foram catequizados por Stavróguin, mas ultrapassaram o mestre no fanatismo de suas crenças). Isso ocorre porque a escrita em arena discursiva expõe posicionamentos diante de uma ideia e suas possibilidades, mas não há fusão em nome de uma verdade objetiva e globalizante.

$\mathrm{O}$ autor de romances polifônicos organiza o contato entre as consciências e representa essas aberturas e possibilidades. Para Bakhtin (2010a, p. 47), “onde começa a consciência começa o diálogo". A pessoa que escreve o romance é apenas uma das vozes da arena romanesca, não uma autoridade cuja verdade deve prevalecer sobre as demais. Trata-se de processo democrático:

A voz do herói sobre si mesmo e o mundo é tão plena como a palavra comum do autor; não está subordinada à imagem objetificada do herói como uma de suas características, mas tampouco serve de intérprete da voz do autor. Ela possui independência excepcional na estrutura da obra, é como se soasse ao lado da palavra do autor, coadunando-se de modo especial com ela e com as vozes plenivalentes de outros heróis (BAKHTIN, 2010a, p. 5). 
Bezerra (2010, p. 11) explica que, para Bakhtin, “o autor participa do diálogo, em isonomia com as personagens, mas exerce funções complementares muito complexas, uma espécie de correia de transmissão entre o diálogo ideal da obra e o diálogo real da realidade". O método de composição não corresponde à ausência do autor, mas à mudança de seu posicionamento. Tudo acontece no campo de visão da personagem e não é intenção do autor manter para si nenhuma informação ou ponto de vista de destaque. A voz do autor Dostoiévski é, portanto, apenas uma entre outras que ressoam em seus romances. Em Os demônios, particularmente, a palavra falada em voz alta tem papel importante e performático, na medida em que abriga verdades tão distintas quanto a revolta do pupilo diante do mestre (Chátov, sempre calado, permite-se berrar diante do mestre Stavróguin), o discurso de redenção de Stiepan Trofímovitch diante da morte, as conspirações políticas de Piotr Vierkhovénski, as bisbilhotices de Lipútin e as questões metafísicas de Kiríllov.

Em Dostoiévski, a palavra é ato pleno. A arena é o palco aberto, repleto de liberdade e possibilidades, em que as personagens se locomovem, coabitam, polemizam, dialogam e vivem. Não há surdez e pontos de vistas privilegiados, pois a postura dialógica envolve movimento, atitude e disposição para o debate. $\mathrm{O}$ discurso interativo, nas arenas, permite que todos participem com perguntas e respostas sobre os grandes mistérios da vida.

\subsection{Escrita e diálogo dos mortos}

Para Bakhtin (2010a, p. 85), os romances de Dostoiévski são constituídos por diálogos "das últimas perguntas e das últimas decisões vitais". Dostoiévski "retrataria não a morte de seus heróis, mas as crises e reviravoltas em suas trajetórias, ou seja, representaria suas vidas no limiar. E então suas personagens ficariam internamente inacabadas (pois a autoconsciência não pode ser acabada de dentro)" (BAKHTIN, 2010a, p. 83). Como forma de discurso, a literatura oferece pontos de vista sobre o ato de morrer e os modos encontrados pelo homem para lidar com a finitude. "Depois do enterro, depois do monumento tumular vem a memória. Tenho toda a vida do outro fora de mim, e aí começa a construção estetizante de sua personalidade, sua consolidação e seu acabamento numa imagem esteticamente significativa" (BAKHTIN, 2011, p. 98) ${ }^{1}$.

\footnotetext{
${ }^{1}$ Grifos do autor.
} 
A tanatografia ${ }^{2}$, a escrita da morte, sobre a morte, reconhece que o discurso não cessa com o trespasse. $\mathrm{Na}$ arena dos mortos, a palavra é viva. Segundo Augusto Rodrigues Silva Jr. (2011, p. 40), "encarar a morte literária é confrontar a ausência de mim no mundo". Tudo o que é dito sobre um sujeito não pode ser conclusivo, pois as narrativas permanecem no mundo após a sua ausência. O discurso sobrevive inclusive ao homem que o proferiu, o que ressalta o caráter de responsabilidade contido no ato de lançá-lo ao mundo. Em Os demônios, a fala de uma personagem é responsiva: tudo se confronta, rivaliza. Sobre o poder de influência humana, o stárietz (líder da igreja ortodoxa) Zóssima declarou, em sermão transcrito em Os irmãos Karámazov [1880], que todos podem e devem iluminar o caminho uns dos outros e que os efeitos dessa atitude são duradouros: "Crê que se não se salvarem agora, mais tarde se salvarão. E se nem mais tarde se salvarem, seus filhos se salvarão, porquanto tua luz não morrerá ainda que tu já tenhas morrido. O justo se vai, mas fica sua luz" (DOSTOIÉVSKI, 2008, p. 436). A palavra dita, portanto, pode fazer paraíso ou inferno do caminho alheio.

Ainda sobre a questão da morte, o discurso literário possibilita contar a história de personagens que não estão mais vivos, mas que sobrevivem no enredo por meio da narrativa alheia. Em experiências mais radicais, o morto retorna para contar a própria história, é dotado de personalidade e talento artístico. É o caso do romance de Machado de Assis Memórias póstumas de Brás Cubas, publicado em 1880 como folhetim, e editado como livro no ano seguinte, no qual há a figura de um defunto-autor:

\footnotetext{
Nas tanatografias há variantes: defuntos que dialogam dramaticamente no além; o encontro entre vivos e mortos; ou ainda no caso de seres que morreram e que voltaram para contar suas experiências do mundo e/ou no além, o interesse reside na personificação daquilo que não pode ser realizado: um defunto falar (SILVA JR., 2011, p. 43).
}

A tradição de falecidos que discursam, bem como a de vivos que adentram o reino dos mortos, remonta aos gregos. Em Catábases: estudos sobre viagens aos infernos da antiguidade, Eudoro de Sousa (2013, p. 22) afirma a importância do inferno como tema clássico e defende que "pelo menos a partir de Virgílio, todo poema épico contém uma catábase (sensu lato)". Todo o estudo se concentra na questão da "relação entre as catábases poéticas e filosoficamente elaboradas e as representações comuns e correntes acerca do destino das almas" (SOUSA, 2013, p. 22). Para o crítico (2013, p.

\footnotetext{
${ }^{2}$ Este tópico é fruto das leituras e discussões ocorridas em disciplinas da pós-graduação, ministrada pelo professor Augusto Rodrigues da Silva Jr. nos anos e 2013 e 2014, cujo tema era literatura e morte. O aporte teórico e literário também possui como referência inicial o texto Morte e decomposição biográfica em Memórias póstumas de Brás Cubas (2008), tese de doutorado do mesmo pesquisador.
} 
157), por meio da catábase, "Virgílio, Dante e Camões bem entenderam que não há epopeia sem a heroica transcenção dos últimos horizontes da experiência humana”.

A questão é relevante para este trabalho na medida em que, em Os demônios, há experiência infernal, concretizada ainda em vida, pela interação dos personagens. Eudoro de Sousa (2013, p. 41) explica ainda que a cultura grega antiga baseava-se na ideia de que a alma "só surge no instante da morte, para logo se encaminhar para o Hades". Ainda sobre aa questão, Daniel Ogden (2010, p. 92-93), no estudo A Companion to Greek Religion, a mitologia grega, à época de Homero, trabalhava com certeza da punição e honra após a morte, de acordo com a forma como o ser humano havia se comportado perante os deuses. A conduta de cada indivíduo, enquanto vivo, determinava onde ele passaria a eternidade.

Em Odisseia, poema épico criado entre os séculos VIII e VII a. C., há uma visita ao reino dos mortos. O astuto (e vivo) Odisseu vai ao lugar "de que falara Circe" (HOMERO, 2011, p. 298). O Hades homérico não é subterrâneo, mas localizado ao nível do mar. Odisseu usou um barco para chegar ao local. Philippe Ariès (2013, p. 32) destaca que neste Hades não havia suplícios, nem sofrimentos, como naquele da Eneida, de Virgílio. A interação entre personagens é elemento a ser destacado, pois no canto XI, o herói conversa com os ex-viventes. Pelo menos é o que ele afirma, pois a visita não contou com testemunhas oculares (vivas). Odisseu encontra figuras notáveis como Tirésias, Jocasta, Pátroclo e Ájax, com quem havia batalhado na guerra de Troia. Um dos diálogos mais importantes da visita é o que ele estabelece com Aquiles. O viajante louva a sorte do antigo guerreiro, que era soberano entre os mortos e, portanto, não deveria lamentar-se por estar falecido. Aquiles discorda e lamenta: "Não tentes reconciliar-me com a morte, ó glorioso Ulisses. Eu preferiria estar na Terra, como servo de outro, [...] do que reinar aqui sobre todos os mortos" (HOMERO, 2011, p. 313).

Silva Jr. (2008, p. 131) destaca a importância do canto XI para uma historiografia literária de mortos que discursam. Ele também destaca a peculiaridade referente aos cantos IX, X, XI e XII: "Neles, o próprio herói conta suas aventuras. Nesse sentido, há uma passagem autobiográfica (em primeira pessoa) dentro do poema" (2008, p. 131). Os momentos destacados são importantes para a presente análise, pois em Os demônios, a personagem suicida principal, Nikolai Stavróguin, também produziu narrativas em primeira pessoa que foram agregadas ao romance, complexificando-o. Até a introdução dos documentos escritos, a história é contada por um narrador externo. 
Odisseia é importante para os estudos romanescos porque se concentra em um personagem, marca do gênero futuro. Silva Jr. (2008, p. 134) aponta que desde o começo da narrativa, Odisseu apresentou tendência ao fingimento, ao alegar insanidade para não participar da guerra. Stavróguin também demonstrou a mesma tendência, ao ocupar lugares simbólicos que não lhe diziam respeito (substituto do tzar, substituto de Deus etc.) e por raramente dizer palavras verdadeiramente sinceras. Silva Jr. (2008, p. 136) destaca ainda que, "no regresso de casa ele é ouvinte, personagem e autor simultaneamente". Stavróguin apresenta a mesma multiplicidade. É ouvinte quando escuta as próprias ideias nas falas de Chátov e Kiríllov; é personagem porque protagoniza a crônica dos acontecimentos da província; é autor, pois escreve uma confissão que é transcrita no romance. É também ator, pois age de forma excêntrica para se observar e tentar compreender os próprios sentimentos durante tais momentos.

Odisseia também serve de inspiração inicial para Diálogo dos mortos, de Luciano de Samósata, texto datado do século II d. C. Ao retratar o mundo subterrâneo, o sírio reúne personagens gregos, homéricos e romanos, numa releitura satírico-crítica do Canto XI. Em Diálogo dos mortos, Luciano compôs uma série de diálogos na qual o elemento cínico-cômico é bastante acentuado. Ao contrário do que ocorre no épico homérico, todos os participantes do diálogo que se passa no Hades luciânico estão mortos. Luciano utiliza-se da liberdade temática possibilitada por um mundo não submetido às leis dos viventes para criticá-los, parodiá-los em pequenos textos dialogados - e não em imensos mundos epicizados ${ }^{3}$. Luciano se expressa de forma consideravelmente distanciada e semi-prosaica. Trata o cristianismo apenas como um credo entre os outros, sem dar a ele qualquer importância particular. O texto é importante pois foi um dos exemplos mais bem conservados, atualmente, da sátira menipeia. Assim como Os demônios, o gênero parodiava os fatos políticos da época.

Em A Divina Comédia (século XIV), a narrativa concentra-se no tema e revela possíveis trajetos posteriores à vida humana. É um livro sobre uma longa jornada a ser percorrida, cujo final é feliz e redentor, bem como um convite para que os vivos refletissem sobre o modo de vida na Terra (pois ele seria responsável por determinar o destino de cada indivíduo). No livro, o autor, Dante, vira personagem de si mesmo e traz a própria imagem personificada no enredo. Na primeira parte, o narrador reflete sobre pecados e punições, crimes e castigos. No Inferno são expostas imagens

\footnotetext{
${ }^{3}$ Observação feita pelo professor Augusto Rodrigues da Silva Jr.
} 
aterrorizantes para o homem medieval, sem esquecer o paraíso (do amor puro e inocente) como meta a ser alcançada. Os mortos retratados pelo Dante-autor possuem a capacidade de interagir com o Dante-personagem, bem como de sofrer e de lembrar da vida que tiveram na Terra. O diálogo é parte fundamental da travessia tanto na Comédia como em Os demônios. À semelhança de Virgílio, que conduziu um Dante vivo pelos abismos, Stavróguin guiou os personagens por todos os círculos de seu profundo inferno pessoal por meio da voz. No romance de Dostoiévski, porém, não há ascensão. A catábase não é sucedida pela anábase, ou seja, não se chega ao paraíso. O lugar eterno dos condenados (ALIGHIERI, 2009, p. 38) é o destino final da viagem de todos os Demônios (especificamente o sétimo círculo, destinados aos suicidas, aos blasfemos e aos que cometem violência contra terceiros).

Outro texto que faz parte da tradição de discursos satíricos nos quais a morte tem papel preponderante é Gargântua e Pantagruel. A prosa de François Rabelais, escrita no século XVI, é focada no corpo, orifícios, na bebida e na comida. Para Bakhtin (2008), morte e renovação estão profundamente relacionados neste texto préromanesco, pois o padecimento é alegre, já que sempre há a possibilidade de ressurreição. Vale a pena destacar a disparidade de tom em relação a Os demônios. No romance dostoievskiano, não há alegria, comicidade, nem redenção na morte, apenas catástrofe e destruição.

Em Hamlet, de 1603, a morte e a possibilidade de retorno do além também é um dos temas centrais. Trata-se de uma peça que gira em torno da vingança. A personagem título, príncipe da Dinamarca, recebe a visita de uma aparição que se identifica como o fantasma de seu pai. O espectro conta ao filho a verdadeira história por trás de seu falecimento: havia sido assassinado por Cláudio, irmão do antigo rei, que agora era casado com a rainha. Motivadas pelo diálogo, as supostas condições da morte do patriarca são encenadas em uma peça de teatro e várias mortes são provocadas. A narrativa contém um questionamento potente, cujas possibilidades de interpretação condensam o questionamento da condição humana: "Ser ou não ser: eis a questão (SHAKESPEARE, 1995, p. 89). A aproximação de Os demônios com a peça shakespeariana será desenvolvida no próximo capítulo.

O tema da descida ao reino das trevas também está presente no imaginário russo. Em Os irmãos Karamázov, na conversa em que Ivan falou a Aliócha sobre A Lenda do 
Grande Inquisidor, é mencionada uma lenda bizantina famosa à época de Dostoiévski ${ }^{4}$. Em A Via-crúcis de Nossa Senhora, traduzida do grego, a mãe de Cristo vai aos infernos, conduzida pelo arcanjo Miguel. "Ela vê os pecadores e os seus suplícios. A propósito, ali existe uma interessantíssima classe de pecadores num lago de fogo: os que submergem no lago de tal modo que não conseguem mais emergir, 'este Deus já esquece"” (DOSTOIÉVSKI, 2008, p. 342). Com a ajuda dos anjos e santos, Maria pede a Deus que salve a alma dos condenados e o pedido é concedido. Nas palavras do Grande Inquisidor também há referência ao romance de Jean Paul ${ }^{5}$, em que Jesus Cristo conversa com mortos que se ergueram das sepulturas. A mensagem tem conteúdo sombrio: os homens estão condenados à solidão, porque Deus não existe.

Dostoiévski também criou mortos que falam. Eles estão em Bobók [1873], verdadeiro diálogo dos mortos menipeico do século XIX. Por meio do método polifônico, o autor responde literariamente aos críticos de seu trabalho anterior, justamente Os demônios, usando técnicas da arte romanesca. Um homem vai ao cemitério, "mar no qual desemboca o rio da vida" (SCIACCA, 2011, p. 56), e escuta os mortos dialogando nos caixões. Em pauta: questões do mundo dos vivos, os odores que exalavam e quanto tempo de consciência ainda teriam. Em suma, a mansão dos mortos é uma espécie de palco no qual se emulam as regras da vida. Há inclusive hierarquia nas relações sociais dos tagarelas. Diante do espirro do vivo Ivan Ivanitch, se calaram. Não há diálogo, propriamente dito, entre os dois mundos, mas há interação, já que os mortos faziam uma verdadeira algazarra, mas foi o barulho do vivo que os interrompeu. Ainda sobre Bobók, Bakhtin (2012, p. 80) afirma que o conto pode ser visto como um microcosmo da obra dostoievskiana, pois contém os mais variados temas:

\begin{abstract}
A ideia de que não existindo Deus nem a imortalidade da alma "tudo é permitido" (um dos principais modelos de ideia em toda a sua obra); o tema, vinculado a essa ideia, da confissão sem arrependimento e da "verdade desavergonhada" [...]; o tema dos últimos lampejos de consciência (relacionado, em outras obras, aos temas da pena de morte e do suicídio); o tema da consciência, situada à beira da loucura; o tema da voluptuosidade, que penetrou nas esferas superiores da consciência e das ideias; o tema da absoluta "inconveniência" e da fealdade da vida desvinculada das raízes populares e da fé popular etc. (BAKHTIN, 2012, p. 80).
\end{abstract}

\footnotetext{
${ }^{4} \mathrm{O}$ diálogo não informa a data de surgimento aproximado da lenda, nem da sua primeira publicação em livro. A nota explicativa de Paulo Bezerra, tradutor do romance, informa apenas que na Rússia circulavam várias edições, e que elas eram anteriores à publicação de Os irmãos Karamázov [1880].

${ }^{5}$ Blumen- Frucht- und Dornenstücke oder Ehestand, Tod und Hochzeit des Armenadvokaten F. St. Siebenkäs, de 1796-1797. Segundo a nota de rodapé da edição utilizada nesta análise, a referência foi indicada por Leonid Grossman.
} 
Todos os pontos elencados por Bakhtin constam, em menor ou maior parte, da narrativa de Os demônios. Os personagens possuem diversos posicionamentos sobre a existência de uma divindade criadora do mundo e o tema é um dos principais na grande arena do romance. Stavróguin não acreditava que seus pecados fossem passíveis de redenção, mas ainda assim escreveu o documento confessional. Por meio das falas de Chátov, a questão da relação do homem com o povo é destacada. O flerte com a loucura é tratado de formas diferentes nas figuras de Liza e Mária Lebiádkina.

Bobók, assim como Os demônios, também trata do contato passível de gerar frutos e influenciar o ambiente: "Sobre uma lápide, ao meu lado, havia um resto de sanduíche: coisa tola e inoportuna. Derrubei-o sobre a terra, pois não era pão, mas apenas sanduíche" (DOSTOIÉVSKI, 2012, p. 16). A epígrafe de Os irmãos Karamázov remonta a esta ideia: "Em verdade, em verdade vos digo: Se o grão de trigo, caindo na

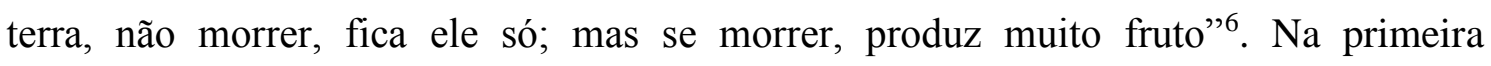
passagem, a "comunhão" com o solo é descrita, ironicamente, por uma égide objetivopositivista: é inerte e não há possibilidade de geração de vida. Na segunda, o contexto é religioso: o sacrifício é fértil e prenhe de vida, numa referência à morte de Cristo.

Em Os demônios, há um terceiro tipo de contato com o terreno, que não é nem neutro, nem positivo. A morte é violenta e não tem motivações nobres, apesar de ocorrer muitas vezes no âmbito da religiosidade. Alguns personagens são ateus e os que se julgam crentes possuem uma fé deturpada, fragilizada pelas situações de arena. A atmosfera do romance é de aridez espiritual. A morte de um não gera nem vida, nem esperança. A semente plantada pela descrença e o fruto colhido pela incerteza moral geram um pão putrefato que aniquila todos aqueles que o consomem.

\footnotetext{
${ }^{6}$ João 12, 24. A tradução foi transcrita da edição de Os irmãos Karamázov utilizada neste trabalho.
} 


\title{
CAPÍTULO 2: MÃOS VIOLENTAS: A QUESTÃ̃ DO SUICÍDIO7
}

\author{
Permanecei firme, bom fado; levai-o ao cadafalso. \\ Fazei com que a corda do destino dele seja nossas amarras, \\ pois que as nossas próprias de pouco nos servem. \\ Se morrer enforcado não é a sina dele, o nosso é um caso perdido. \\ William Shakespeare, A tempestade
}

\subsection{A morte voluntária}

A possibilidade do suicídio indica que o ser humano tem certo controle sobre a quantidade de tempo em que permanece no mundo, o que subtrai o caráter imprevisível da morte. A possibilidade de um ser humano retirar-se voluntariamente da existência está diretamente ligada a questões como a imortalidade da alma, a relação do homem com um ser superior, com a sociedade (PAPERNO, 1997) e com o significado (ou a falta de um) da experiência humana. Qual o propósito de estar no mundo e o que existe depois da experiência terrena? Há consequências para aqueles que escolhem em qual momento devem ter acesso a tais respostas? Impossível dizer. Enquanto houver vida, a morte será pergunta sem resposta e o suicídio persistirá como tema de reflexão.

As discussões sobre o suicídio datam da Antiguidade. Reflexões sobre o tema, por exemplo, em Sócrates, associadas à questão da imortalidade da alma, já estão latentes. Um dos principais textos sobre o tema é Fédon, de Platão. Nele, Sócrates afirma que "o comum das pessoas está, provavelmente, longe de presumir qual o verdadeiro alvo da filosofia, para aqueles que porventura o atingem, e ignoram que a isto se resume: um treino para morrer e de estar morto" (PLATÃO, 2000, p. 40). Para o grego, a morte era alívio em relação às aflições da vida, além de apresentar o positivo aspecto de libertar a alma do corpo. Sócrates (como retratado por Platão) acreditava que corpo e alma coexistem em uma pessoa. O filósofo acreditava que as pessoas que se despojassem dos prazeres do corpo e privilegiassem as questões da alma em vida teriam direito a habitar um lugar feliz após a morte. Sobre a questão do suicídio, quando questionado por Cebes sobre "o desejo que o filósofo tem de seguir aquele que morre", Sócrates responde que "há uma doutrina propalada nos Mistérios, segundo a qual nós,

\footnotetext{
${ }^{7} \mathrm{O}$ título do capítulo refere-se ao Canto XI, do Inferno, de A Divina Comédia, no qual é descrito o sétimo círculo do Inferno.
} 
homens, estamos como que num cárcere, donde ninguém deve libertar-se ou evadir" (PLATÃO, 2000, p. 38). Para o grego, a morte voluntária seria uma forma de desconsiderar a vontade dos deuses. Ou seja, ele apresentava argumentos contrários ao suicídio, mas muito se discutiu no pensamento ocidental se a morte dele poderia ou não ser considerada ato suicida, pois o filósofo ingeriu o veneno antes da hora ${ }^{8}$.

Nas Leis, livro IX, Platão condena aqueles que cometem suicídio sem as seguintes motivações: "a) sem que a cidade o obrigue a isso por um decreto justo; b) sem que um infortúnio inevitável e extremamente doloroso o acometa; e, por fim, c) sem que uma vergonha incontornável torne sua vida insuportável” (PLATÃO apud PUENTE, 2008, p. 18). Na incidência dessas situações, o ato seria justificado. Na ausência, seria sinal de covardia. O indivíduo transgressor deveria ser enterrado em local distante, sem identificação. Na mesma linha, Aristóteles também foi crítico do suicídio. Em Ética a Nicômaco (1973), ele discorre sobre o ato, que não era permitido pela lei, e segundo a lógica do filósofo, o que a lei não admitia explicitamente, ela proibia. Aniquilar-se para fugir das agruras da vida era um gesto de injustiça contra a pólis. O suicida vai em direção à morte não por motivos honrados, mas para sair do alcance do mal. O julgamento está em consonância com o que afirmou Platão: ambos veem na morte voluntária um gesto de pusilanimidade.

Coimbra (2011) explica que no período helenístico a filosofia deixou de buscar a sistematização das reflexões e passou a tratar de temas mais próximos dos cidadãos da pólis. Epicuro, filósofo localizado neste momento do pensamento, refletiu sobre a impossibilidade absoluta de experimentar a finitude. Para o helenista, a morte "enquanto se está vivo, permanece um nada incognoscível e, quando morremos, perdemos a possibilidade de conhecê-la, pois já não teremos nenhuma faculdade disponível para tal. Logo, a morte não pode ser considerada nem um bem, nem um mal" (COIMBRA, 2011, p. 20). Sobre o posicionamento de Epicuro, Puente (2008) descreve que, segundo o grego, o indivíduo deveria manter uma posição de impassibilidade, sem sentir aversão, nem medo do fatídico fim. Se alguém busca aniquilar-se por estar cansado da existência, o responsável por esse desejo é o próprio indivíduo, por ter conduzido a vida de forma errada. Porém, a crítica contra o suicídio não é absoluta, já que ele considera algumas possibilidades em que o ato seria plausível, como no caso de dores extremadas.

\footnotetext{
${ }^{8}$ A questão é discutida pormenorizadamente em $O$ julgamento de Sócrates, de I.F. Stone.
} 
Argumentos favoráveis ao suicídio foram oferecidos pelos estoicos. Puente (2008) explica que eles foram os primeiros a pensar na morte de forma neutra. A abordagem respingou também na reflexão sobre a morte voluntária. "O termo eulógos exagogé ('saída racional') para designar o ato de matar-se é de autoria estoica e já nos indica o modo como esse ato, para eles, pode ser justificadamente levado a cabo, isto é, racionalmente" (PUENTE, 2008, p. 23). Diógenes, por exemplo, considerava algumas motivações que possibilitariam a um sábio tomar tal decisão: por razão patriótica, por relações de amizade ou por estar acometido por alguma enfermidade sem cura. Para Cícero, o fato de alguém decidir-se pela vida não significava necessariamente um ato de sabedoria. O filósofo acreditava ser possível haver situações em que o mais inteligente fosse que o sábio feliz decidisse evadir-se da vida e que o ignaro infeliz permanecesse vivo. O valor máximo para ele era levar a vida de forma racional, portanto, tinha a obrigação de sair dela também de forma sábia. Aquele que vive submetido aos vícios é infeliz independentemente da decisão que tome em relação ao próprio fim.

Sêneca também foi defensor do trespasse voluntário, mas apenas em algumas situações, como, por exemplo, o ato causado por algum motivo relacionado à pátria ou aos amigos, ou aquele causado por uma pessoa que não deseja ser escravizada, associando o ato à ideia de liberdade e coragem. Ele não considerava justificado o suicídio como forma de escapar das agruras da vida. Apenas no caso da incidência de grave doença que abalasse as faculdades racionais a possibilidade poderia ser considerada, pois não seria racional manter-se vivo apenas para tolerar a agonia. É importante frisar que ele julgava se uma vida havia sido ou não completa, não pelo número de anos transcorridos, mas pela forma como o indivíduo a conduziu. Uma existência na qual se alcançou a sabedoria já é perfeita e não precisa de extensão ideal.

Não há proibição expressa contra o ato de tirar a própria vida na Bíblia. Quando citada, a prática é associada a pessoas corajosas, como Sansão, Saul e Eleazar. O primeiro cristão a descrever o suicídio de forma negativa, taxando-o como crime, foi Santo Agostinho. No texto cristão canônico A cidade de Deus, lê-se: "De todos quantos o perpetraram contra si podemos admirar a grandeza de ânimo, não, porém, louvar a sabedoria. [...] É antes fraqueza de alma a incapacidade de sofrer a dura servidão do corpo ou o desvario da opinião" (AGOSTINHO, 1961, p. 84). Segundo Puente (2008, p. 15), Agostinho considera a ação inserida na proibição do sexto mandamento, ou seja, aquele que diz: "não matarás". Tomás de Aquino, na Suma de teologia, também criticou o autoaniquilamento. Segundo o filósofo e teólogo, o ato era triplamente ofensivo, pois 
significava uma iniquidade contra o próprio indivíduo, a coletividade e contra o Criador. Na mesma linha, em 1563 a Igreja Católica oficializou a condenação ao ato por meio do Concílio de Trento, que critica a ação voluntária de modo irrestrito.

No século XVI, Michel de Montaigne cita, nos Ensaios, vários exemplos (Livro II, Capítulo III), para defender também variantes voluntárias. Recupera o pensamento de Cícero e afirma que filosofar é aprender a morrer. Segundo Veneu (1993, p. 39), ele percebe que várias figuras ilustres tiraram as próprias vidas e o fato "impressiona-o como demonstração de coragem e de serenidade frente à morte, e discuti-los é ao mesmo tempo uma forma de investigação sobre o tema e de autoexame das próprias reações diante dessa possibilidade" $"$.

Em 1897, Émile Durkheim realizou uma profunda investigação sobre a morte voluntária e articula o tema, afastando-o do domínio da moralidade. Em Suicídio, defende que a sociologia precisa de um objeto próprio de investigação para existir e usa o tema como pontapé da busca. $\mathrm{O}$ estudioso defende que as causas que levam as pessoas a tirar as próprias vidas não estão na dicotomia corpo-alma, mas na existência coletiva, ou seja, a sociedade (verdadeiro tema da sociologia). Para Durkheim, suicídio é "todo caso de morte que resulte direta ou indiretamente de um ato positivo ou negativo, praticado pela própria vítima, sabedora de que devia produzir esse resultado" (DURKHEIM, 1982, p. 16). Segundo o pensador alemão “o verdadeiro suicídio, o suicídio triste, está em estado endêmico nos povos civilizados. Distribui-se mesmo geograficamente como a civilização" (DURKHEIM, 1982, p. 240) ${ }^{10}$.

Anos mais tarde, com o lançamento de $O$ mito de Sísifo, em 1942, Albert Camus enfrenta o tema de maneira pontual e declara, de forma categórica e ousada, que na verdade "só existe um tema filosófico realmente sério, o suicídio". No grande ensaio, a personagem da mitologia grega é utilizada como metáfora para uma crítica da vida humana na terra, cuja falta de sentido seria absurda. O pensador compara o seu castigo eterno imputado pelos deuses a Sísifo, ou seja, empurrar uma pedra ao pico de uma montanha e repetir o gesto infinitamente depois que ela caísse, à existência. Chama-o de "trabalhador inútil dos infernos", pois foi condenado a um ofício sem esperança. O presente trabalho voltará com frequência à noção de falta de sentido e à desesperança numa tentativa de compreender o autoaniquilamento de Stavróguin, bem como o

\footnotetext{
${ }^{9}$ No século XVIII, David Hume, em Do suicídio, refuta a ideia da decisão como um ataque contra Deus. Schopenhauer, em Parerga e Paralipomena [1851], discorda da ideia do suicídio como ato imoral.

${ }^{10}$ Apesar de o trabalho ser posterior à publicação de Os demônios, a menção é importante, pois tanto o texto de Durkheim quanto o de Dostoiévski abordam o suicídio sob aspectos sociais.
} 
inferno instaurado ao seu redor. Sobre a razão e viver e suicídio, Camus (2010, p. 43) afirmou: "Viver sob este céu sufocante nos obriga a sair ou ficar. A questão é saber como se sai, no primeiro caso, e por que se fica, no segundo. Defino assim o problema do suicídio e o interesse que se pode atribuir às conclusões da filosofia existencial".

Do mesmo modo que a filosofia, a arte, como forma de discurso, não deixou de problematizar a questão. O drama shakespeariano apresenta vários defuntos voluntários, entre eles Romeu e Julieta, Brutus, Cleópatra, Otelo e Ofélia. Em 1774, Goethe publicou Os sofrimentos do jovem Werther, aliando suicídio e Romantismo no mais alto grau. À data do lançamento, o romance epistolar alemão foi publicado sem o nome do autor. Usou-se o artifício do suposto editor que reúne cartas para levá-las ao público. O anonimato foi ato cauteloso acertado, pois o romance recebeu acusação de fazer apologia ao suicídio e teve a circulação proibida. Werther é um advogado que se encanta pela bela Charlotte, que infelizmente é noiva de outro. O jovem tenta fugir da paixão, mas acaba sendo tomado por ela, bem como por um sentimento de tristeza e melancolia, que o levam a matar-se com um tiro de pistola. Em Madame Bovary, romance de Gustave Flaubert publicado em 1857, Emma ingere veneno e tira a própria vida como forma de se livrar do acúmulo de dívidas. Em Os miseráveis [1862], de Victor Hugo, a personagem Javert não suporta o peso da magnanimidade do rival Jean Valjean e se atira no Rio Sena.

$\mathrm{Na}$ literatura russa do século XIX, a incidência de personagens suicidas também é alta. Segundo Richard Freeborn (1992, p. 258), os textos produzidos entre os anos de 1855 e 1880 estavam focados em emancipar o ser humano, fosse por meio da questão feminina, do suicídio niilista, ou da liberdade alcançada por meio do conhecimento científico. A primeira personagem suicida notável encontra-se no conto A pobre Liza, de Nikolai Karámzin, de 1792. O texto narra a trajetória de uma jovem órfã que se apaixona por um aristocrata. Ao descobrir que o amado havia sido infiel, afoga-se intencionalmente em um lago. Em Avenida Niévski [1835], de Nikolai Gógol, um pintor ingênuo pensa ter encontrado a mulher ideal, mas descobre tratar-se de uma prostituta. Desolado, busca refúgio no ópio e depois comete suicídio. Em Polikushka [1853], de Liev Tolstói, narra-se o caso de um mujique que se enforca após perder o dinheiro da ama. No romance Anna Karenina, escrito pelo mesmo autor em 1878, o tema da morte voluntária está presente na trajetória de quase todos os personagens principais. A incapacidade de compreender o mundo fez com que Levin considere a possibilidade de se matar, mas ele não leva a ideia adiante. Vronsky não consegue lidar com o perdão do 
rival, marido de Anna, e chega a atirar em si mesmo, mas sobrevive. A personagemtítulo é a única que obtém sucesso no propósito definitivo. Perde a vida ao se jogar na frente de um trem. Trata-se de uma das mais belas cenas de suicídio da literatura, segundo o crítico literário americano James Wood (2012).

Nenhum escritor russo do século XIX explorou o tema do suicídio de forma tão abrangente quanto Dostoiévski. O escritor utilizou-se do tema para problematizar as questões mais sombrias da vida humana. $\mathrm{O}$ aniquilamento do corpo foi estilizado como escolha desesperada daqueles que haviam rompido todos os laços fundamentais: sejam eles afetivos, sociais ou religiosos.

\subsection{O contexto do suicídio na Rússia do século XIX}

Segundo Noah Shneidman (1984), no livro Dostoevsky and Suicide, há vinte e dois suicídios na obra do autor russo, além de várias tentativas não concretizadas. Quinze dessas situações estão nos trabalhos de ficção; sete, no Diário de um escritor. O tema chamou a atenção porque a Rússia "sofreu uma epidemia de suicídios" no período de 1860 até 1880. Umas das causas principais do fenômeno foram as Reformas Gerais ocorridas em 1861, que emanciparam os servos. Para Dostoiévski, o período de transição subsequente foi de pura desordem. Para Paulo Bezerra, as reformas "abriram caminho para o desenvolvimento do capitalismo e de uma sociedade burguesa na Rússia” (BEZERRA, 2005, p. 41). O país passou por um período de transição, marcado por conflitos internos entre a modernidade, o czarismo, as utopias socialistas, o movimento eslavófilo e o niilismo. Shneidman (1984) destaca o aumento do número de suicídios na Rússia de acordo com o desenvolvimento da urbanização e da industrialização. O estudioso aponta que em tempos de guerra as pessoas famintas raramente se matam, pois elas possuem um objetivo de vida: alimentar a família.

Shneidman (1984, p. 14) descreve que, no período compreendido entre 1819 e 1875, o número de suicídios na Rússia cresceu de 17,6 para 29 por milhão de habitantes. O fenômeno, mais perceptível na parte ocidental do país, principalmente em São Petersburgo, pode ser entendido por meio dos números (exaustivos, mas necessários). Ocorriam cerca de 12 a 15 suicídios por mês na capital. Em 1870, foram 125 suicídios na cidade; em 1871, o número chegou a 152; em 1872, as pessoas mortas voluntariamente somaram 167. Entre os anos 1870 e 1873, o percentual de mulheres que se matava, em relação aos homens, era de cerca de $20 \%$. A taxa de suicídio 
aumentava com a idade. Entre os anos 1869 e 1878, 50 crianças da faixa etária entre oito e dezesseis anos tiraram as próprias vidas em São Petersburgo.

Paperno (1997) explica que, até as Reformas de Pedro, o Grande, no começo do século XVIII, as leis russas não tratavam do suicídio, que era tema da jurisdição da Igreja Ortodoxa. Para a tradição religiosa, o homem, criado à imagem e semelhança de Deus, havia perdido características divinas e se tornado sujeito à morte por causa do pecado original. Enquanto a proibição do autoaniquilamento na Igreja Católica baseavase na interpretação do sexto mandamento, na igreja russa ela provinha das 18 respostas de Timóteo de Alexandria. Membro do Segundo Concílio Ecumênico de Constantinopla de 381 , ele caracterizou o ato como condenável e decretou que nenhuma oração devia ser conduzida em nome do morto, mas que o clérigo devia investigar se o morto estava sob o domínio das faculdades mentais ao realizar o ato. Circulares clericais de 1417 proibiam expressamente que os suicidas fossem enterrados na igreja, ou que ele tivesse direito a cerimônias funerárias: os corpos deveriam ser jogados em lugares remotos.

Segundo Paperno (1997, p. 94), na sociedade russa após Pedro, o Grande, havia a tendência, por parte dos que discordavam do positivismo, de enxergar o suicídio como resultado do culto à ciência e ao ateísmo. A morte voluntária era símbolo do destino de uma sociedade sem Deus: a diminuição da existência a nada, um corpo excluído de sua alma. Apesar disso, porém, muitas pessoas de fé também se matavam. Em 1666, diante de uma possível vinda do Anticristo, houve suicídio em massa. A taxa de mortes voluntárias era maior entre as seitas do que entre os ortodoxos. Shneidman (1984) descreve que no período compreendido entre os séculos XVII-XVIII, mais de dez mil pessoas morreram por causa de autoimolações. Paperno afirma ainda que, a partir do século XIX, os estudos ocidentais tendiam a considerar o suicídio como ato causado por doenças mentais, inclusive com abertura de corpos para busca de anormalidades cerebrais. Dostoiévski estilizou essa tentativa positivista de encontrar causas científicas para todas as questões humanas, principalmente em Memórias do subsolo.

Shneidman (1984, p. 17) discorre sobre os psicólogos e psicanalistas que estudam a questão por meio de dados obtidos por autópsias. Trata-se de um método que consiste na análise de informações sobre o comportamento da pessoa às vésperas da morte. O estudioso destaca, porém, que nenhum estudo científico pode revelar o verdadeiro estado mental de um homem quando tira a própria vida, pois as variáveis racionais e emocionais que agem sobre ele são inúmeras. Segundo Paperno (1997), por volta de 1830 o suicídio passou a ser tratado como questão social, não mais como 
problema daquele que o cometeu, mas com causas geradas pela sociedade. A investigação em torno do suicídio foi invadida por estatísticas morais, dados como: idade, sexo, raça, religião, profissão, condições econômicas etc. Dostoiévski também trabalha com essa abordagem "sociológica" nos personagens que tiraram a vida por endividamento, por exemplo. Há casos em O idiota e n'Os demônios.

Segundo o Regulamento do Exército e da Marinha de Pedro, o Grande, o corpo do suicida deveria ser pendurado pelas pernas, ou enterrado em um lugar nefasto. Caso alguém fosse acusado de auxiliar um suicídio, poderia ser processado por cumplicidade em assassinato e condenado a quinze anos de trabalhos forçados (SHNEIDMAN, 1984, p. 18). Em 1845, a legislação criminal russa sofreu alterações, com consequências diretas na questão da morte voluntária. As leis a respeito do assunto permaneceram inalteradas até a Revolução de 1917, ou seja, estavam vigentes durante o período em que Dostoiévski escreveu a sua obra. Paperno (1997) descreve que, à época, o Estado, além de um funeral cristão, negava aos suicidas, com exceção de insanidade, o cumprimento de seus últimos desejos. Nos casos malsucedidos perpetrados por cristãos, eles deveriam ser levados às autoridades eclesiásticas para as devidas penalidades.

Nos anos 1860, a circulação dos jornais aumentou e a imprensa se tornou importante espaço de acesso à informação (PAPERNO, 1997). Em 1866, o crime se tornou o assunto principal dos periódicos, que passaram a cobrir julgamentos e a dedicar mais espaço aos casos de suicídio. Sempre atento às questões de seu tempo, Dostoiévski percebeu a recorrência das publicações e identificou o interesse do público pelos casos mais dramáticos. Por meio da imaginação, estilizou filosoficamente a questão do crime e do suicídio em todos os grandes romances da obra: Crime e castigo (Raskólnikóv, Svidrigáilov), O idiota (Míchkin, Ippolit), Os demônios (Stavróguin, Kiríllov), O adolescente (Kraft, Olya) e Os irmãos Karamázov. Em todos os livros se encontram arenas discursivas que movimentam questões sobre a vida e o ato de tirá-la.

\subsection{Variáveis da autodestruição}

Como visto anteriormente, o caos social foi decisivo para o aumento do número de suicídios. O fato de os personagens dostoievskianos estarem frequentemente em espaços limítrofes e habitando a indecisão também é metáfora relacionada ao período histórico vivido pela Rússia. Segundo Lukács (1968, p. 171), “os personagens de Dostoiévski percorrem com dignidade a estrada socialmente necessária da 
autoflagelação. A maneira como se desintegram e como se destroem constitui o mais ardente protesto até então pronunciado contra a ordem social da época”. Em relação ao suicídio literário, Shneidman defende que seja psicologicamente convincente, para que o leitor não o considere um mero recurso artístico do autor para abolir um personagem que não lhe serve mais (SHNEIDMAN, 1984), abordagem que Dostoiévski explorou com competetência. A tragédia dos primeiros heróis possui um componente social (a miséria, a falta de aceitabilidade em determinado círculo de pessoas etc.), mas o verdadeiro sofrimento é existencial e/ou autoinflingido. Variante de seres que aspiram a destinos que não lhes cabem.

Não há qualquer suicídio concretizado nos primeiros trabalhos do autor. Isso não significa que o elemento autodestrutivo não seja componente da personalidade dos personagens. Apesar da ausência da morte objetiva em alguns casos, muitos passaram por um processo de falecimento simbólico ${ }^{11}$. Em Gente pobre [1846], Dievuchkin recorre à bebida quando se percebe diante da perda de Varvara, cuja afeição dá sentido a sua miserável vida. Em $O$ duplo [1846] Goliádkin deseja uma melhor posição social e aceitação dos superiores. Para compensar o que lhe falta, percebe-se diante de um duplo, que o trata de forma tão humilhante quanto os outros, levando-o à desintegração mental. Em $O$ senhor Prokhártchin [1846], a personagem título é um avaro que guardou muito dinheiro, do qual não chegou a usufruir. Morre na pobreza, depois de delirar. Há forte culpa no protagonista relacionada ao dinheiro. Trata-se de visão completamente terrena do trespasse, que, segundo o narrador, "arranca a cobertura de todos os nossos segredos, intrigas e artimanhas". Ao final, o morto apresentou feição pensativa e pareceu até aliviado por, finalmente, ter se libertado da angústia financeira.

Shneidman (1984, p. 26) destaca que a tendência autodestrutiva dos primeiros personagens encontra-se no fato de eles não conseguirem lidar com o cotidiano, de não serem capazes de tomar as rédeas dos próprios destinos, caminhando em direção ao fim ou à insanidade. Em A senhoria [1847], o desejo de ficar perto da amada Katerina leva Ordínov a alugar um quarto na casa do homem a quem ela é inteiramente submissa. Em vez de ajudar a moça, complica a situação dela, destruindo o destino de ambos. Em Polzunkov [1848], o protagonista demonstra tendências autodestrutivas ao tentar agradar

11 O estudioso contemporâneo Andrew Solomon realizou, em O Demônio da meia-noite: uma anatomia da depressão, uma consideração sobre o suicídio que elucida a comparação realizada por esse parágrafo. Para o estudioso, a fronteira que separa a autodestruição da morte voluntária não é clara. "Pessoas que empurram sua própria decadência são protossuicidas." Para o estudioso, "tentativas de suicídio são de escopo variado e vão desde atos totalmente deliberados e orientados para um único objetivo até aqueles levemente autodestrutivos" (2014, p. 251). 
a todos, o que agrava sua sensação de inferioridade. Em Coração fraco [1848], o protagonista, cujos patrões o admiram e a noiva o ama, enlouquece por ser incapaz de lidar com a própria felicidade. Foi arruinado pela própria bem-aventurança. Em Ladrão honesto [1848], um homem alcoólatra que rouba para alimentar o próprio vício é perdoado pelo ofendido, mas enlouquece, incapaz de lidar com a própria consciência. Em Noites brancas [1848], o abnegado protagonista desiste da amada sem lutar e oferece ajuda para procurar o noivo perdido da moça. Em Niétotchka Niezvânova [1849], Efimov acredita que é um violinista brilhante e culpa a sociedade e a esposa por não ter conseguido a notoriedade de que se julgava merecedor, vive para alimentar uma vaidade obsessiva. Ao assistir ao concerto de um violinista realmente talentoso, não consegue lidar com a própria mediocridade, enlouquece e morre.

Shneidman (1984) destaca que o processo de autodestruição dos personagens pré-siberianos $^{12}$ (ou seja, de Gente pobre até Niétotchka Niezvânova) é inelutável, porém lento e gradual. Nos grandes romances, a autoaniquilação (simbólica ou literal) ocorre de forma drástica e violenta. Na fase inicial do autor, a "pulsão de morte"13 ainda está em equilíbrio com o instinto de vida. Shneidman (1984, p. 32) destaca que o livro mais sombrio que antecede os grandes romances de Dostoiévski é, paradoxalmente, o mais otimista. Em Recordações da casa dos mortos [1862], Dostoiévski descreve o prisioneiro em toda a sua inesgotável sede de vida, para os quais a esperança da liberdade já é motivo para permanecer vivo. Não é o encarceramento que leva o homem a querer se matar, mas a ausência de esperança (sentimento que esse trabalho aproxima à sensação de inferno dos vivos e que torna a possibilidade do suicídio muito próxima do sujeito nele mergulhado, como será tratado nos próximos capítulos). Quando se perde a perspectiva de condições melhores, a existência se torna sem sentido, e o instinto autoaniquilador se fortalece. A violência demonstrada pelos presos da casa dos mortos é quase sempre manifestação de instinto de vida e de autopreservação.

Ainda no panorama autodestrutivo, em $O$ sonho do titio [1859], depois de ser esbofeteado pela amada, Vasia torna pública uma carta de amor que ela havia escrito. Cheio de remorso, tenta se matar. Trata-se da primeira tentativa de suicídio da obra dostoievskiana. A personagem busca, com o ato, atrair a compaixão da amada, além de puni-la e fazer com que ela sinta remorso pelo sofrimento que causou: "Naquela ocasião

\footnotetext{
$12 \mathrm{O}$ termo diz respeito ao período anterior àquele em que Dostoiévski cumpriu pena na Sibéria (18491854), sob acusação de ter conspirado contra o czar.

13 Em Além do princípio de prazer, Sigmund Freud trata a questão como curiosidade, espécie de especulação do sujeito que anseia, inconscientemente, ir ao encontro da morte.
} 
eu tinha uma ideia: como seria bonito eu estar estirado na cama, morrendo de tísica, e tu te consumindo toda, te mortificando, sofrendo por ter me levado à tísica" (DOSTOIÉVSKI, 2012, p. 175).

Em Memórias do subsolo [1864], o protagonista defende o direito de o homem agir contra si mesmo para afirmar a própria liberdade, contrariando vantagens objetivas: "O homem precisa unicamente de uma vontade independente, custe o que custar essa independência e leve aonde levar" (DOSTOIÉVSKI, 2000, p. 39). Também são expostas situações de humilhação autoimpostas, como o episódio no qual o homem do subsolo anda de um lado para o outro fingindo ignorar os adversários, enquanto deseja, desesperadamente, ser notado por eles. É um homem doente, mas recusa-se a procurar um médico. Shneidman (1984, p. 35) sugere que a solidão absoluta do homem imerso no subsolo é uma espécie de suicídio espiritual, metáfora que ele também atribuiu ao protagonista de Um jogador [1866], Aleksei Ivanovich. A personagem apresenta incapacidade de lidar com os próprios impulsos racionais e com o vício por fortes emoções (o que realmente sustentaria a jogatina, muito mais que a busca financeira).

Em Crime e castigo [1866], enquanto Mikolai fracassa ao tentar se enforcar, o criado, Filip, concretiza o ato. Afrossíniuchka se atira no canal, mas é salva pela polícia. Sônia confessa a Raskólnikov que já havia pensado em se matar e o protagonista interpreta que "o que a impediu até agora de atirar-se no canal foi a ideia do pecado" (DOSTOIÉVSKI, 2001, p. 334). Svidrigáilov dispara uma bala contra a cabeça, levado pelo tédio e pela desesperança (à semelhança de Stavróguin, em Os demônios). Em $O$ idiota [1869], Rogójin considera a ideia de se "atirar n'água antes de entrar em casa" (DOSTOIÉVSKI, 2002b, p. 31) após desviar dinheiro do pai. Hippolit, personagem tísico, afirma que, por causa da doença, "o suicídio talvez seja a única coisa que eu ainda tenha tempo de começar e terminar por minha própria vontade" (DOSTOIÉVSKI, 2002, p. 468). O tio de Ievguiêni Pávlovitch se suicida após proporcionar um “desfalque de trezentos e cinquenta mil rublos no erário" (DOSTOIÉVSKI, 2002b, p. 393).

Em O eterno marido [1870], Lisa conta a Vieltchâninov que o pai, Páviel Pávlovitch, havia tentado se enforcar na frente dela. Quando o encontra, Vieltchâninov questiona as intenções de Pávlovitch. Ele responde que "estando bêbado, é possível que tivesse vindo à cabeça alguma coisa nesse sentido" (DOSTOIÉVSKI, 2003, p. 100). Em vez de se matar, a personagem foge da cidade, numa espécie de suicídio social. Em $O$ sonho de um homem ridículo [1877], a personagem, que não é nominada, passa meses planejando o ato, mas desiste diante do encontro com uma menina que lhe pede ajuda. 
"Sabia que enfim nessa noite certamente me mataria, mas até lá quanto tempo ainda iria ficar sentado à mesa - isso não sabia. E é claro que teria me matado, não fosse aquela menina” (DOSTOIÉVSKI, 2003a, p. 97). Há afirmação da ação, seguida de desistência. Em Os irmãos Karamázov [1880], o tema da morte voluntária ganha destaque por meio da personagem Smierdiákov. Após confessar para Ivan que havia assassinado e roubado Fiódor Pavlovitch Karamázov, resolve tirar a própria vida.

Os suicidas de Dostoiévski são catorze do sexo masculino, oito do sexo feminino, cinco crianças, vários são jovens de mais ou menos vinte anos, entre eles Stavróguin, Kiríllov, Smierdiákov. A realização mais comum é por enforcamento, mas também há suicídios com arma de fogo, envenenamento, afogamento e saltos de janelas. O suicídio na obra dostoievskiana é mais que estilização, frequentemente trata-se da aplicação de alguma teoria ou argumento ético ou filosófico de algum personagem. Pode ser praticado como expressão do livre-arbítrio, revolta ou vingança, mas quase nunca é sinal de remorso. É um tema por meio do qual o escritor problematizou algumas das próprias crenças, ou seja, de que apenas a fé é capaz de livrar um homem de tendências autodestrutivas. Ao fazê-lo, porém, nunca perdeu de vista que os personagens eram vozes fundamentais na arena discursiva.

A morte natural raramente possui destaque na obra de Dostoiévski. Os falecimentos geralmente se dão por meio de causas extremas e envolvem a perda da razão ou algum tipo de crime. Schneidman (1984) destaca que a abordagem de Dostoiévski ao tema difere da realizada por outros romancistas russos. O autor nunca encara falecimentos como questão biológica, nem analisa os aspectos psicológicos do trespasse. Ele cita (1984, p. 10) o pensamento de V.I. Kaigorodov, segundo o qual as fatalidades em Dostoiévski são geralmente causadas pela violação ética por parte da personagem, ou daqueles que podem influenciar o seu destino. Como a maioria dos dos homens incorpora ideias em ação, o fracasso de um pensamento geralmente leva à destruição do herói, assim como a morte dele tende a indicar convicções corrompidas.

Para Bakhtin (2010a, p. 337), a representação da morte em Dostoiévski não é "fato orgânico - objetificado do qual a consciência responsavelmente ativa do homem não participe: no universo de Dostoiévski há apenas assassinatos, suicídios e loucuras, ou seja, apenas mortes como atos responsavelmente conscientes”. Dostoiévski não representa o último momento a partir do interior, mas de um ponto de vista externo, a partir do modo como os outros a observam. A partir do momento em que a morte não interfere com o essencial, ou seja, a consciência que a personagem tem de si mesmo, ela 
não pode defini-lo. Para Bakhtin, "em seu mundo, onde o dominante da imagem do homem é a autoconsciência e o acontecimento fundamental é a interação de consciências isônomas, a morte não pode ter nenhum valor conclusivo e esclarecedor da vida" (BAKHTIN, 2010a, p. 83). Ainda sobre a questão, Paperno (1997) afirma que Dostoiévski trata de casos individuais e não estatísticos. Ele se concentra não no corpo do morto, mas nas consciências e nas ideias dos vivos.

Quando um personagem se mata, portanto, é para problematizar as escolhas tomadas e as crenças abandonadas, bem como para evidenciar deuses aniquilados, demônios assimilados e infernos habitados. É o resultado final de uma luta entre o bem e o mal, entre deus e o diabo, cujo campo de batalha é o coração do homem ${ }^{14}$.

Desesperança de vida tornada em ato de morte.

\title{
2.4. O ato extremo: suicídio em Os demônios
}

Em Os demônios, o autoaniquilamento é pano de fundo para o enredo e tema dos diálogos mais significativos do livro. Nos momentos decisivos, porém, os personagens fazem mais que falar sobre o ato. O número significativo de mortes voluntárias, bem como o eterno retorno ${ }^{15}$ do tema em modalidades discursivas, já é indicativo de que o suicídio de um tem influência na decisão de morte do outro. No romance, são registradas treze mortes. Cinco personagens atentam contra as próprias vidas. Um jovem não identificado, de aproximadamente 19 anos, dispara no peito depois de gastar todas as economias da família, destinada à compra do enxoval da irmã:

\begin{abstract}
Tudo indica que se suicidou por volta da meia-noite, embora seja estranho que ninguém tenha ouvido o disparo e só o tenham descoberto hoje, à uma da tarde, depois de baterem à porta e, não obtendo resposta, arrombarem-na. A garrafa de Chateau-Yquem estava consumida pela metade, sobrara também meio prato de uvas. O tiro fora dado com um pequeno revólver de três tiros diretamente no coração. Correra muito pouco sangue, o revólver caíra no tapete. O próprio jovem estava meio deitado num canto do divã. Pelo visto a morte fora instantânea; não se notava nenhum sinal da agonia da morte no rosto. A expressão era serena, quase feliz, faltava pouco para estar vivo (DOSTOIÉVSKI, 2004, p. 321).
\end{abstract}

Shneidman (1984, p. 69) destaca que a morte é descrita pelo narrador de forma semelhante a um relato de jornal. Nada é dito sobre o passado do rapaz além do fato de

\footnotetext{
14 “É horrível que a beleza seja uma coisa não só terrível, mas também misteriosa. Aí lutam o diabo e Deus, e o campo de batalha é o coração dos homens. Aliás, é a dor que ensina a gemer" (Dmitri Karamázov em Os irmãos Karamázov).

${ }^{15}$ Expressão oriunda de A gaia ciência, de Friederich Nietzsche.
} 
que foi enviado para a cidade para realizar a compra. O episódio demonstra a perversão dos jovens que foram à cena da catástrofe, já que a visitaram para se divertir. "De um modo geral, em toda desgraça do próximo há sempre algo que alegra o olho estranho não importa quem seja” (DOSTOIÉVSKI, 2004, p. 321). Não houve tristeza, nem compaixão pelo destino do jovem ou pela família dele, só curiosidade mórbida. Os comentários realizados ilustram anestesiamento diante da cena, que foi vista como algo banal. "Um observou que aquela era a melhor saída e que o rapazola não podia ter pensado nada mais inteligente" (DOSTOIÉVSKI, 2004, p. 321).

O suicídio reaparece no fim do romance, quando Liámchin, depois de ter participado do assassinato do estudante Chátov, sente remorso, confessa tudo às autoridades e tenta se matar, sem sucesso. Por se tratar de personagem secundário, a tentativa tornou a trama dele mais complexa:

\begin{abstract}
No entanto, continuo falando de Liámchin. Assim que ficou só (Erkel, confiando em Tolkatchenko, fora para casa ainda antes), fugiu imediatamente de casa e, é claro, logo soube como andavam as coisas. Sem passar sequer em casa, precipitou-se numa fuga sem rumo. Mas a noite estava tão escura e o empreendimento era tão terrível e trabalhoso, que depois de atravessar umas duas ou três ruas, voltou para casa e trancou-se por toda a noite. Parece que pela manhã tentou o suicídio, mas falhou (DOSTOIÉVSKI, 2004, p. 646).
\end{abstract}

O "parece" do narrador não imprime certeza ao fato. Ainda assim, ele fez questão de registrar os boatos, significativos no contexto da corrente de morte que varreu a cidade. Tanto no caso do jovem como no de Liámchin, houve tentativa de fuga. Escolheram escapar da vida para não ter que lidar com as consequências negativas de suas ações, para fugir à responsabilidade pelo que fizeram. Michele Sciacca (2011) enxerga ausência de coragem nos suicídios realizados com fins de "desvanecimento", aqui representado pelo livramento da prisão. Mataram-se (ou tentaram) por remorso, porque não possuíam vontade de realizar as próprias ressurreições (nem acreditavam nessa possibilidade) por meio do cumprimento de suas penas.

Outro tipo de suicídio é cometido por Kiríllov, que atira no crânio por motivos filosóficos. Segundo o engenheiro, "aquele para quem for indiferente viver ou não viver será o novo homem. Quem vencer a dor e o medo, esse mesmo será Deus. E o outro Deus não existirá" (DOSTOIÉVSKI, 2004, p. 120). Paperno (1997) explica que, para Dostoiévski, a crença em Deus e na imortalidade era condição necessária da vida humana. Por isso, as vidas dos heróis sempre giram, de uma forma ou de outra, em torno da questão identificada por Ivan Karamázov: "Destruindo-se nos homens a fé em sua imortalidade, neles se exaure de imediato não só o amor como também toda e 
qualquer força para que continue a vida no mundo. E mais: então não haverá mais nada amoral, tudo será permitido, até a antropofagia” (DOSTOIÉVSKI, 2004, p. 109).

Há um suicídio protagonizado por uma criança (Crime e castigo e $O$ adolescente também exploram essa variante da morte voluntária). Matriócha, filha dos locatários de um apartamento no qual o protagonista Nikolai Vsievolódovitch Stavróguin habitou por um determinado período, foi violada sexualmente por ele e se enforcou, não sem antes afirmar que havia matado Deus. O violador, influenciado (em parte, pois as motivações são complexas e variadas), pelo gesto da criança, também se mata, no momento tenso do romance.

O suicídio de Stavróguin, protagonista de Os demônios, ocorreu por etapas. Foi comparado a personagens literários, o que evidenciou o aspecto fragmentado e polifônico de sua personalidade. Vivenciou o esfacelamento psicológico e deixou rastros mortais por onde passou. Por meio dos diálogos em que tomou parte, revelou-se uma pessoa cujo tédio e descrevnça haviam sufocado a vontade de viver. Despediu-se do mundo por meio de um demorado deslizamento em direção ao abismo. Experimentou publicamente o processo do fim, em duelos discursivos que terminaram com a morte de si ou do outro. Nenhuma esperança foi poupada na arena de Stavróguin.

Como apontamos no início, o título do capítulo coincidia com o sétimo círculo do Inferno de Dante. Nele, encontram-se aqueles que cometeram violência contra si, contra o outro, ou contra Deus. "Pode alguém contra si ter mão violenta / ou contra a sua fortuna, e é no segundo / giro que o seu pecado, em vão, lamenta / quem se privou da vida em vosso mundo" (ALIGHIERI, 2009, p. 96). Mais uma vez, a escrita de morte serve para balizar os atos do morrer. Em Dostoiévski, a polifonia aliada à tanatografia, com a variante suicidária, amplia e aprofunda os horizontes do suicídio literário ${ }^{16}$.

\footnotetext{
${ }^{16}$ N. do Orientador.: Ao percorrer as ações suicidárias em Doistoiévski e n'Os demônios percebemos o jogo entre a palavra única, a palavra plural, a palavra escrita e o tema do suicídio literário. A possibilidade de suicidar o outro - ato do ideólogo na tanatografia. Na questão da palavra individual, ela está presente na rede mais chã, a dos boatos, das atitudes que desejam desestabilizar o outro para que ele morra - é o desejo matá-lo, discursivamente, para que a autoatitude pareça melhor, heroica, ou sábia. No segundo caso, a palavra plural, da arena discursiva, agrega a mais chã tentativa de totalizar-se e revela o desejo de outrem suicidar uma única figura (como no episódio de Chatóv). No âmbito das performances sociais: o escritor responde ao seu tempo, enquanto seus desafetos, movidos por suas ideias, faziam circular boatos capciosos, panfletos, falas e escritos jornalístico medianos - a palavra plural que se desmancha no ar (o caso de Bobók ainda é o melhor exemplo). Ao contrário de romances, como os de Dostoiévski, capazes de ter algum impacto na história da cultura (palavra escrita e bem acabada). Neste sentido, mais do que um romance sobre o terrorismo, como afirma mestre Paulo Bezerra, o livro representa tentativas totalitaristas, variantes de mal-estar da cultura que chegou no século XIX ou no XXI são respondidas pela palavra e a melhor palavra ainda é a ação.
} 


\section{PARTE II}

SUICÍDIO LITERÁRIO 


\title{
CAPÍTULO 3: DIÁlOGOS DE MORTE EM OS DEMÔNIOS: A ARENA INFERNAL DE STAVRÓGUIN
}

\author{
Nossos atores, como lhe antecipei, \\ eram todos espíritos e desmancharam-se no ar. \\ William Shakespeare, A tempestade
}

\subsection{Da biografia à tanatografia}

"Deixai toda esperança, ó vós que entrais." Diante do Inferno ${ }^{17}$ não há muros nem grades. Há apenas um aviso àqueles que se encontram na antessala do reino das almas, localizado no interior da Terra, cuja topografia vai se tornando mais profunda à medida que a gravidade dos pecados aumenta. Ao entrar, deve-se abandonar a mais remota possibilidade de avistar o céu. O Paraíso Perdido ${ }^{18}$ é a consciência irrevogável e inelutável da impossibilidade de ascensão do abismo. A morte da esperança, aquele que foi o único item na caixa esvaziada de Pandora, portanto, é condição primordial daquele que adentra o Tártaro. O inferno dostoievskiano, assim como o de Dante, não apresenta cadeados, a porta metafórica está aberta. $\mathrm{O}$ acesso ao reino das trevas se dá pela palavra, por um processo pessoal de tornar-se inferno ${ }^{19}$ a ponto de, muitas vezes, não mais percebê-lo. Ao contrário do que ocorre no poema italiano, porém, no qual a catábase é seguida pela anábase, não há ascenção no romance russo. Em Os demônios, o narrador registrou o processo de alastramento da descrença metafísica de Stavróguin, bem como a sua queda final e definitiva.

Stavróguin já está morto quando o narrador inicia o relato, o que possibilita uma leitura tanatográfica de Os demônios. No fim da vida, o outro é seu complemento, pois tem acesso a pontos de vista aos quais, a rigor, aquele que falece não tem acesso. "Enquanto meus, o nascimento e a morte não podem tornar-se acontecimentos da minha própria vida" (BAKHTIN, 2011, p. P 95). Na escrita da morte, portanto, “o problema da imortalidade é trocado por aquele do 'imortalizar-se' nas obras e nas lembranças" (SCIACCA, 2011, p. 56). Segundo Silva Jr. (2011, p. 44), “importa perceber que toda tanatografia é organizada no momento em que o fio é cortado. Naquilo que é dito depois do fim. Daquilo que ocorre após o último ato". Portanto, a versão oficial do romance

\footnotetext{
${ }^{17}$ Dante Alighieri, A Divina Comédia.

${ }^{18}$ Referência ao poema de John Milton, que responde dialogicamente à Divina Comédia .

${ }^{19}$ Referência à epígrafe-guia deste trabalho, outra resposta dialógica ao Inferno dantesco.
} 
não é a do morto, já que a narrativa é contada pela perspectiva de um narrador cronista morador da província na qual os fatos ocorreram. Há tanatografia, pois, segundo Silva Jr., "na literatura, o personagem volta para existir, enquanto recordação, na lembrança dos outros, e na memória coletiva" (SILVA JR., 2011, p. 42). Nesse sentido, Camus afirmou que "na realidade, não há experiência da morte. Em sentido próprio, só é experimentado aquilo que foi vivido e levado à consciência" (CAMUS, 2010, p. 29). Para compreender o falecimento da personagem, portanto, é preciso começar pela perspectiva daqueles que sobreviveram.

No começo, o cronista fornece uma apresentação biográfica de Stiepan Trofímovitch: "Ao iniciar a descrição dos acontecimentos recentes e muito estranhos ocorridos em nossa cidade que até então por nada se distinguia, por inabilidade minha sou forçado a começar um tanto de longe, ou seja, por alguns detalhes biográficos [...]" (DOSTOIÉVSKI, 2004, p. 15). Segundo Frank (2003, p. 622), “o capítulo inicial pouco dramático e (para Dostoiévski) incomumente lento tenta realçar, por comparação, a tensão do restante do livro e fornecer um equivalente formal apropriado para o tema da conspiração secreta e da usurpação subversiva". O aspecto psicológico do drama não está tanto na parte narrada em terceira pessoa, que em geral tenta se colocar de forma objetiva. $\mathrm{O}$ horror e a experiência infernal estão presentes, principalmente, nas vozes, na polifonia, no balanço entre peso e leveza ${ }^{20}$ entre o que é dito e o que se cala.

Na narração da morte de Chátov, por exemplo, o elemento mais carregado de dor e violência é a voz. Aqueles que sujaram as mãos e se arrependeram bradaram berros e urros, pois era a única forma de expressar uma angústia que não cabia mais em palavras. No incêndio que matou os Lebiádkin, foi o silêncio polissêmico de Stavróguin que permitiu a concretização da catástrofe. Para Camus (2010, p. 99): “Um homem é mais homem pelas coisas que silencia do que pelas que diz".

Segundo Bakhtin (2011, p. 139), "a forma biográfica é a mais "realista", pois nela há menos elementos de isolamento e acabamento. Um nome importante na multiplicidade de vozes do romance é o de Stiepan Trofímovitch, homem da geração de 1840. Liberal e idealista, valoriza a arte e se recusa a subjugar-se às ciências positivas. Segundo Frank (2003), esses homens eram chamados de "supérfluos", acusados de pensar demais e agir de menos, de serem tão fascinados pelo belo que se tornavam incapazes de qualquer atividade prática. Stiepan Trofímovitch faz parte da primeira

\footnotetext{
${ }^{20}$ Confira o capítulo Leveza em Italo Calvino, Seis propostas para o próximo milênio.
} 
geração da intelligentsia russa: influenciada pela cultura europeia e plena de ideias elevadas. Pai de Piotr Vierkhoviénski, foi tutor de Stavróguin e responsável pela educação de Chátov, Dária Pávlovna e Lizavieta Nikolaievna, o que significa que a maioria dos personagens bebeu da fonte ocidental desde a juventude, fato que marca a formação de todos. Portanto, o surgimento da arena de Stavróguin teve início em um passado conjunto, o que começa a explicar a força da interação entre eles. O poder de influência foi potente porque seminal, plantado na infância (seja ela relacionada à primeira fase da ocidentalidade na cultura russa, ou à tenra idade dos personagens) para ser colhido em fase adulta - numa espécie de positivismo e determinismo estilizado.

É com o tutor, pessoa suscetível e vulnerável, que Stavróguin estabelece a primeira relação afetiva. "Mais de uma vez ele despertou o seu amigo de dez ou onze anos à noite com o único fim de desabafar em lágrimas os seus sentimentos ofendidos ou lhes revelar algum segredo doméstico" (DOSTOIÉVSKI, 2004, p. 49). Sobre a formação do caráter emocional do fidalgo, o narrador escreve que o professor incutiu no pupilo "a primeira sensação, ainda indefinida, daquela melancolia eterna e sagrada que uma alma escolhida, uma vez tendo-a experimentado e conhecido, nunca mais trocaria por uma satisfação barata" (DOSTOIÉVSKI, 2004, p. 50). Ele destaca positivamente o fato de terem se separado quando o jovem vai para o liceu, aos dezesseis anos.

Segundo Frank (2003, p. 497), Stavróguin foi desenvolvido progressivamente. Dostoiévski não havia imaginado um personagem tão complexo. Inicialmente, havia planejado escrever sobre um príncipe, que ora aparecia como figura medíocre, ora se mostrava um fidalgote altivo que passava por um algum tipo de regeneração. Em março de 1870, decidiu que ele seria um suicida, "mais trágico do que satírico, porque sua capacidade de acreditar em seu próprio renascimento acarreta em sua autodestruição" (FRANK, 2003, p. 531). Segundo o biógrafo, Dostoiévski esquematizou a personagem da seguinte forma: "O Príncipe - um homem que ficou entediado. Produto do século russo. É altivo e sabe como ser ele mesmo, isto é, manter-se afastado dos aristocratas, dos niilistas [...] (mas para ele permanece a questão - o que é ele mesmo?) Ele responde - nada” (FRANK, 2003, p. 531). Assim nasce Stavróguin, a partir de um título de nobreza e da dúvida. A associação com Hamlet é intencional e explícita, já que é indicada em Os demônios. Apesar de serem personagens de gêneros diferentes (drama/romance), não é impossível aproximá-los teoricamente ${ }^{21}$. Bakhtin enxerga em

${ }^{21}$ Em Anatomia da influência, Harold Bloom afirma que a questão do gênero tem pouca relevância para a interpretação do autor inglês, principalmente de Hamlet, pois se trata de um poema ilimitado, que 
Shakespeare (2010, p. 38) elementos embrionários da polifonia, que só não se concretiza de fato pois a figura do narrador está ausente. $\mathrm{O}$ autor inglês é aludido já no surgimento da personagem no romance, aproximação que é retomada ao longo do texto. A referência shakespeariana, ocorre no título do segundo capítulo da primeira parte do romance ("O Príncipe Harry - O pedido de casamento"). Varvara Pietrovna, mãe de Stavróguin, e Stiepan Trofímovitch chamam-no tanto de Príncipe Harry, da peça Henrique IV, como de Hamlet, da tragédia homônima. Decidem-se pelo segundo paradigma. Destaca-se o fato de que Stiepan Trofímovitch enxerga a vida de forma literária e é o primeiro a aproximar Stavróguin de uma figura ficcional.

Ambas as aproximações são válidas. No início da peça Henrique $I V$, o jovem Harry comporta-se como arruaceiro. O herdeiro do trono de Gales chega a participar de um assalto para se divertir. "Nunca houve príncipe tão devasso e amalucado", descreveo Hotspur na cena II, ato V, da primeira parte do drama histórico. Da mesma forma, o jovem Stavróguin se comporta de forma desregrada. "Não é que jogasse ou bebesse muito; contavam apenas sobre alguma libertinagem desenfreada, sobre pessoas esmagadas por cavalos trotões, sobre uma atitude selvagem com uma dama da boa sociedade, com quem mantinha relações e depois ofendeu publicamente" (DOSTOIÉVSKI, 2004, p. 50). O russo frequenta círculos escusos: anda em companhia de bêbados e veste farrapos. Ao saber do modo de vida do filho em Petersburgo, a mãe implora que ele vá morar com ela e Stavróguin aparece na província. Do mesmo modo, Harry também anda com um grupo de pessoas indigno de sua condição social. Dentre eles, está John Falstaff, um bufão bêbado e espirituoso que não tem cerimônias com o futuro rei. A voz desempenha papel preponderante na compreensão da peça shakespeariana, mas com efeito diferente do que ocorre em Os demônios, pois quando Stavróguin fala, causa admiração idólatra ou ângústia metafísica, enquanto o bobo se expressa para provocar o riso, função preponderante no contexto protodialógico e reflexivo das peças do bardo: "O príncipe é um João-ninguém, um palhaço. Se ele estivesse aqui e me dissesse isso, eu o espancaria como a um cão", diz, ao saber que Harry havia dito que seu anel era de cobre, não uma relíquia valiosa.

Em Os demônios, há amizade semelhante na juventude de Stavróguin, apontada pelo próprio, em relação a Lebiádkin: "Naquele período Nikolai Vsievolódovitch chamava esse senhor de seu Falstaff, pelo visto trata-se de algum antigo caráter 
burlesque, do qual todos riem e o qual permite que riam de si mesmo contanto que lhe paguem por isso" (DOSTOIÉVSKI, 2004, p. 190). A citação complexifica a caracterização do fidalgo como personagem com ressonâncias shakespearianas, pois revela que o próprio é leitor do bardo e já se colocou, em menor ou maior grau, no lugar do príncipe Harry. A comparação, por ter sido autodeclarada, revela traço importante da autoconsciência do príncipe russo, ao mesmo tempo em que ganha leveza. Se foi levantada de forma galhofeira, é porque ele mesmo não a leva tão a sério.

Destaca-se ainda que, em Henrique $I V$, o trono ao qual Harry tem direito é uma situação a efetivar-se. Em Os demônios, há um trono simbólico, vazio, representado pelo grande papel - messiânico, até - que os personagens esperavam que o protagonista exerça em seus destinos. A mãe projeta nele ambições sociais que não conseguiu concretizar. Vierkhoviénski o imagina como líder de uma possível revolução niilista. Chátov e Kíríllov se permitem catequizar, cada um a seu modo, por antigas reflexões religiosas do fidalgo. Stavróguin ocupa os espaços apenas na medida em que sua impactante presença, no sentido de que é belo e altivo, desperta emoções e expectativas, pois não é do interesse dele qualquer responsabilidade e missão para com os outros.

As aproximações com Hamlet são variadas. No período em que a narrativa do drama e do romance se concentram, as figuras paternas não estão (a rigor) presentes fisicamente, o que não significa que há ausência simbólica. Em Hamlet, o pai está representado pela aparição vista pelo príncipe, ou seja, há uma espécie de retorno do reino dos mortos, fato interessante à tanatografia ${ }^{22}$. Em Os demônios, a metáfora paterna adquire significado mais amplo, na medida em que remete ao conflito entre gerações. Essa leitura, da ideologia como herança transmitida pelos mais velhos e deturpada pelos mais novos, foi indicada por Ivan Turguêniev no romance Pais e filhos (1862).

No romance de Turguêniev, Bazárov, primeiro niilista autodeclarado, condena as abstrações filosóficas (exemplo: quando uma pessoa está com fome ela não precisa de lógica para levar alimento à boca, portanto, as abstrações são desnecessárias), desconsidera o modelo tradicional de família e prega a insignificância da arte. Possui um único princípio: "Nossas ações se fundamentavam naquilo que julgamos útil. [...] Nos tempos atuais, o mais útil é a negação: nós negamos" (TURGUÊNIEV, 2004, p. 85). Os demônios pode ser considerado uma resposta à questão levantada pelo romance de Turguêniev, ou seja: quais as consequências resultantes de um movimento niilista

${ }^{22}$ Segundo Philippe Ariès, os fantasmas faziam parte da realidade de Shakespeare - isto é óbvio com a presença do Rei Hamlet na peça homônima. 
russo? Olhados em conjunto, os suicídios de Os demônios oferecem uma possível resposta à pergunta: o não-crer é postura autodestrutiva, seja do ponto de vista individual, seja do ponto de vista político-nacional.

Ainda sobre a questão da descrença, Frank (2003, p. 623) afirma que Stiepan Trofímovitch "transmitiu toda a sua incerteza moral e instabilidade a seu desafortunado pupilo sem fornecer algo de positivo que neutralizasse seus efeitos perturbadores, e o resultado foi deixar um vazio doloroso no centro de Stavróguin". O jovem nunca superou essa disposição triste, introspectiva e reflexiva: vários dilemas religiosos e existenciais do fidalgo são discutidos (dúvidas sobre a existência de Deus e sobre como preencher o tédio existencial etc.) mas nenhum deles é solucionado. Stavróguin permanece uma incógnita do começo ao fim da narrativa, tanto para o leitor, como para os personagens e para si mesmo. Segundo Luigi Pareyson (2012, p. 35), "Stavróguin é o enigma que todos buscam decifrar".

Turguêniev, como um dos mais importantes escritores russos da época, reforçou Hamlet como figura importante e atual para a literatura. Em palestra proferida em 1860, parcialmente transcrita em ensaio teórico na edição de Pais e filhos utilizada neste trabalho, o escritor desenvolve uma análise sobre o príncipe dinamarquês. Aponta as seguintes características da personagem: “A análise, antes de tudo, e o egoísmo, e por isso a incredulidade. Ele vive totalmente para si, é um egoísta; mas nem o egoísta pode crer em si mesmo; só se pode crer no que está fora de nós e acima de nós. Porém, esse $e u$ em que ele não crê é caro a Hamlet" (TURGUÊNIEV, 2004, p. 305). Do mesmo modo, todo o livro é construído no desdobramento do ser ou não ser de Stavróguin, principalmente por meio dos diálogos de que participa e dos documentos escritos por ele. Turguêniev destaca a mesma capacidade de luta interior na personagem de Shakespeare: "Hamlet inflige feridas a si mesmo, se tortura; em suas mãos, há também uma espada: a espada de dois gumes da análise" (TURGUÊNIEV, 2004, p. 307).

Shakespeare ecoa, direta ou indiretamente, em toda a narrativa de Os demônios. As referências se dão tanto no âmbito formal, ou seja, na forma como o romance é construído, como na constituição da personalidade e na semelhança com personagens essenciais. O gênero dramático e o universo ficcional do Bardo fornecem pano de fundo para a trama correspondente à influência exercida por Stavróguin na mente dos outros personagens. Falas espectrais que, ao serem recebidas pelos ouvintes, são renovadas, atualizadas e ganham nova força. Portanto, a análise aproveitará o modelo fornecido pelo romance e retomará a comparação com o autor inglês ao longo do texto. 
A questão do ser ou não ser também está presente na história de toda a Rússia do século XIX, já que o país se digladiava, em arena, em torno da própria identidade frente às influências internas e externas. Para Dostoiévski, as forças negativas estavam em maior peso, o que havia desencadeado um processo de autodestruição nacional.

\subsection{Stavróguin, ator e espectador de si mesmo}

O narrador de Os demônios é o correspondente de Horácio na trama shakespeariana: aquele que fica vivo (uns dos poucos, diga-se de passagem) para contar a história. Na peça, a personagem tem acesso a vários elementos da vida do príncipe, inclusive ao fantasma, ao fingimento da loucura etc. No caso do romance dostoievskiano, o narrador não participa, nem tem acesso a detalhes da vida de Stavróguin entre a primeira e a segunda estada da personagem na província (período em que a ação do romance se concentra, inclusive no que diz respeito às mortes $\mathrm{e}$ suicídios). As poucas informações são reveladas pelos outros personagens ou chegam até ele por meio de boatos.

A exposição que o narrador faz de suas lembranças envolvendo Stavróguin e suas façanhas são importantes pois começam a delinear a personalidade fragmentada. Segundo Pareyson (2012, p. 50), "intimamente desdobrado, ator e espectador, ao mesmo tempo, ele vê e estuda o seu sósia, enquanto comete os atos mais ignóbeis e assim se ilude, como se nisso não tomasse parte". O duplo do protagonista de $O s$ demônios apontado pelo estudioso não é literal, mas metafórico: Stavróguin age, mas é como se projetasse as próprias ações para outra pessoa que não ele mesmo, para que, vendo-as de fora, conseguisse entender as próprias motivações: um espectador de si mesmo. Quando age, não está interessado em obter um resultado objetivo e positivo, mas em perceber as possibilidades de sua personalidade e força. Desinteressado da vida, só encontra momentos de ligeira vivacidade no "sutil prazer de uma nova experiência, pela fria malvadeza in vitro, pela indiferente crueldade de um 'estudo', pelo prazer de dispor da vida e do destino de outrem a seu talante" (PAREYSON, 2012, p. 50). Na mesma linha, Kiríllov comparou o casamento de Stavróguin com Mária Lebiádkina com um estudo "levado a cabo por um homem farto" (DOSTOIÉVSKI, 2004, p. 191).

As ações públicas realizadas por Stavróguin, ao contrário daquelas promovidas na intimidade, as quais tendem mais para a observação ou para o ensimesmamento, são inusitadas, no sentido de fugirem às regras sociais, o que causa estranhamento à 
sociedade. Por exemplo, arrasta um homem da sociedade pelo nariz e morde a orelha do governador sem motivo algum. É preso pelo segundo episódio, o que resulta em ataque de fúria e delírio que leva os médicos a diagnosticarem-no como fora do juízo. "Ivan Óssipovitch, homem delicado e sensível, ficou muito atrapalhado, mas o curioso é que ele considerava Nikolai Vsievolódovitch capaz de qualquer ato de loucura em pleno gozo da razão" (DOSTOIÉVSKI, 2004, p. 59). Os moradores da província questionou até que ponto Stavróguin havia sido afetado por uma doença nervosa, ou se havia alguma intenção por trás das "performances"23.

No primeiro capítulo da segunda parte ("A noite"), há um trecho da narrativa, conduzido pelo narrador, no qual o elemento visual é tão acentuado que parece dar diretrizes a um ator que se dispusesse a representar a cena. O fragmento destoa de outros momentos da crônica, parece mais um relato de uma pessoa que narra um acontecimento enquanto ele está ocorrendo. O tom descritivo do capítulo é incongruente com a posição do narrador-cronista. Ele não estava presente à cena e afirma ter, como fonte de sua narrativa, os relatos ouvidos de terceiros, após a morte de Stavróguin. Escreve como se estivesse assistindo-a clandestinamente, quando só Varvara viu o filho, e mesmo assim por um curto período, que não corresponde ao total do trecho narrado.

O trecho é importante, pois é o único, em todo o enredo, em que Stavróguin fica sozinho (com exceção do momento do suicídio, mas nem mesmo a hora da morte recebe tal tratamento "ocular": quando o leitor é informado da morte, ela já havia ocorrido). De toda forma, o trecho concentra-se em um instante após visita de Piotr Stiepánovitch. Várvara Pietrovna vai visitar o filho e o encontra adormecido. O fragmento é trabalhado de forma a produzir tensão e expectativa, pois o desencadeamento da ação é lento e descritivo. O fidalgo é retratado de modo a ressaltar a sua aparência vampiresca: palidez, imobilidade. O narrador menciona, em detalhe simbólico, um som de relógio, o que evidencia que a passagem de tempo realmente passou a ser marcada de forma diferente, mais vagarosa. O elemento sonoro contribui para incrementar a sensação de mistério. Ao ver o filho completamente inerte, a mulher sente o coração acelerar:

Ficou um tanto impressionada com o fato dele ter adormecido tão depressa e que conseguisse dormir daquele jeito, sentado tão reto e imóvel; quase não dava para ouvir a sua respiração. O rosto estava pálido e severo, mas como que inteiramente congelado, imóvel; tinha o sobrolho um pouco levantado e o cenho franzido; terminantemente, parecia uma figura de cera,

\footnotetext{
${ }^{23}$ Em Hamlet, Polônio afirma que toda loucura tem método, frase que problematiza de forma resumida a questão do fingimento da loucura relacionado ao príncipe da Dinamarca. Assim como no drama inglês, portanto, Stavróguin carregava uma aura de incerteza em relação a sua sanidade.
} 
sem alma. Ficou uns três minutos a observá-lo respirando com dificuldade, e de repente o medo a assaltou; saiu na ponta dos pés, parou à porta, benzeu-o às pressas e afastou-se sem ser notada, com uma nova sensação pesada e uma nova angústia (DOSTOIÉVSKI, 2004, p. 231).

Stavróguin dorme por mais uma hora, na qual não esboça o menor movimento: "Se Varvara Pietrovna permanecesse ali por mais uns três minutos, certamente não teria suportado a sensação angustiante desse imobilismo letárgico e o teria acordado" (DOSTOIÉVSKI, 2004, p. 231). O sono acentua o caráter de morto-vivo, de sonambulismo espiritual de Stavróguin. Sobre sono, Sciacca (2011, p. 53) diz que "dormir é ato vital que fecha a própria vida em parênteses", é "quase uma partícula de morte". Stavróguin acorda e o criado aparece com um "sobretudo quente, um cachecol e um chapéu numa das mãos". Stavróguin diz as horas, "nove e meia”, em voz baixa. A declaração auxilia na construção de uma atmosfera de solenidade à cena descrita, impressão corroborada pelo pedido de Stavróguin para o outro vesti-lo.

Há descrição dos trajes de Stavróguin antes de sair da casa, o que não ocorre com frequência, com exceção de momentos em que o narrador quer enfatizar traços de exotismo nos personagens. Ou seja, a exploração de um detalhe significa aprofundamento de questões psicológicas. Exemplo: sabe-se que Lebiádkin veste o traje do amor para chamar a atenção de Liza, mas não há detalhes sobre a indumentária. Outra personagem que também recebe descrição do figurino é Stiepan Trofímovitch, em dois momentos principais. O narrador conta que o homem usou o mesmo traje a vida toda, o qual foi concebido por Varvara Pietrovna. A roupa o faz parecer um retrato de Kúkolnik, conhecido poeta da época, o que ressalta o lado fictício da vida levada por ele. "Ela o inventou e foi a primeira a acreditar em sua invenção. Ele era algo como um sonho...” (DOSTOIÉVSKI, 2004, p. 24). Quando vai à casa de Varvara Pietrovna para receber a "sentença" sobre seu casamento, também se vestiu com esmero particular.

De volta à descrição do sono de Stavróguin, o clima de mistério da cena indica a importância do que estava prestes a acontecer, ou seja, o diálogo de Stavróguin com Kiríllov, o principal do romance sobre o tema do suicídio. A descrição das vestimentas de Stavróguin pretende destacar que o momento era mais solene e importante que os anteriormente narrados: "Notando que estava com um paletó de veludo leve, pensou e ordenou que trouxessem outra sobrecasaca de tecido, usada para visitas noturnas mais cerimoniosas" (DOSTOIÉVSKI, 2004, p. 231). O momento é relatado de forma visual, quase como se Stavróguin fosse um intérprete prestes a entrar no palco ou participar de um ritual. A atmosfera de construção de mistério persiste no decorrer da cena: 
Por fim, inteiramente vestido e de chapéu, fechou a porta por onde Varvara Pietrovna havia entrado, tirou a carta escondida de debaixo do mata-borrão e saiu calado para o corredor, acompanhado de Aleksiêi Iegórovitch. Do corredor chegaram à escada de pedra estreita dos fundos e desceram para $\mathrm{o}$ vestíbulo que dava direto para o jardim. Em um canto do vestíbulo havia uma lanterna e um guarda-chuva grande, preparados de antemão (DOSTOIÉVSKI, 2004, p. 232).

A cena de terror, as vestes fúnebres e o indicativo de escuridão pelo caminho ressaltam o aspecto de homem que caminha rumo à própria morte. Percebe-se que o momento foi planejado, o que indica que a personagem caminhava conscientemente para o fim trágico, na surdina, sem chamar a atenção para os seus planos soturnos. Stavróguin pergunta se há perigo de alguém vê-lo ou ouvi-lo, ao que o criado responde que Varvara Pietrovna já estava dormindo e que, portanto, ele não corria riscos: "Deus o abençoe, senhor, mas só em caso de boas ações" diz o criado ao se despedir, como se antecipasse que algo ruim estava para acontecer (DOSTOIÉVSKI, 2004, p. 233).

Não só o narrador trata Stavróguin como se ele fosse um ator, pois as personagens atribuem a ele papéis grandiosos. A caracterização é feita de forma exagerada e indica idolatria, como se ele fosse um falso deus. Fiédka disse: “[...] diante do senhor, é como se eu estivesse diante do Verdadeiro - eis que estou aqui pela quarta noite esperando Sua Graça nesta ponte" (DOSTOIÉVSKI, 2004, p. 260). De Lebiádkin, escutou: "Não importa que então me considerassem o seu Falstaff de Shakespeare, mas o senhor representava tanto no meu destino!.. Hoje eu ando com grandes temores, e espero unicamente do senhor um conselho e a luz" (DOSTOIÉVSKI, 2004, p. 264). Vierkhoviénski o apresenta como líder do movimento revolucionário. "Você é o chefe, você é a força; ficarei apenas ao seu lado, como secretário" (DOSTOIÉVSKI, 2004, p. 375). Stavróguin sabe da responsabilidade que exercia no destino alheio. "Por que todo mundo espera de mim o que não espera dos outros? Por que tenho de suportar o que ninguém suporta e implorar por fardos que ninguém consegue suportar?" (DOSTOIÉVSKI, 2004, p. 287). Kiríllov afirma que ele buscava tais imputações e que deve aguentá-las, caso contrário, não haveria mérito. Frank (2003, p. 632) afirma que era impossível para o rapaz "carregar o fardo do bem, mesmo que sinta o desejo de fazê-lo, porque seu irreprimível egoísmo continua a impedi-lo”.

Portanto, a indicação de que a trama contém personagens que representam algum tipo de papel - consciente ou não - vem do próprio livro. No começo da "crônica", o narrador explica que Stiepan Trofímovitch havia criado para si uma mítica de homem perseguido pelas autoridades e que não conseguia imaginar-se sem essa 
farsa. "Gostava apaixonadamente desse papel, a ponto de me parecer que sem ele nem poderia viver. Não é que eu o equipare a um ator de teatro: Deus me livre, ainda mais porque eu mesmo o estimo" (DOSTOIÉVSKI, 2004, p. 15). Ao defender que não pretendia comparar a vida do amigo com a performance de um ator de teatro, a alguém que age segundo as diretrizes de enredos inventados, o narrador chama mais atenção para a semelhança que se tivesse escrito sobre ela de forma neutra.

Ao conferir tom negativo à comparação, indica compromisso com os fatos e relatos, os quais foram substrato para sua "crônica", mas sem deixar de lado a consciência de que o texto possuiria leitores, bem como o compromisso com a reputação das pessoas retratadas. Segundo Bakhtin (2011, p. 152): “A vida biográfica e a enunciação biográfica são sempre cercadas de uma fé ingênua, seu clima é quente; a biografia é profundamente crédula mas de uma credulidade ingênua (sem crises), pressupõe um ativismo bondoso". Ou seja, desde o início do romance há indicação de que entre os demônios há pessoas merecedoras de serem lembradas positivamente, numa espécie de arena rememorativa, Stiepan Trofímovitch principalmente.

A abordagem cuidadosa, sempre disposta a apontar uma qualidade ao lado de um traço negativo, não tem a ver apenas com o fato de ambos terem sido próximos. Stiepan Trofímovitch é o único que encontra algum tipo de redenção ao fim do romance. Admitir o aspecto "intérprete" do caráter do amigo seria retirar a força de sua quase conversão e associar a experiência sublime final da personagem a mais um prolongamento imaginativo de sua mente fértil. O narrador pretendia estabelecer que os seus relatos eram calcados na representação verídica para que não houvesse inverossimilhança no destino de Stiepan Trofímovitch. Deveria parecer possível a representação de um liberal que ao fim da existência abandonou o egocentrismo humanista para se entregar a algo maior: "Se os homens forem privados do infinitamente grande, não continuarão a viver e morrerão no desespero. [...] Todo homem, quem quer que ele seja, precisa inclinar-se diante daquilo que é a Grande Ideia" (DOSTOIÉVSKI, 2004, p. 642). Ou seja, em um romance cujo tema central é caos e destruição moral que assolou a província (mas também uma época, toda uma tendência cultural), a salvação está acessível para aqueles que se dobram diante de algo maior, desde que não se trate de falsos ídolos (doutrinas ideológicas, artísticas e pessoas, por exemplo), mas de algo que transcenda o homem - Deus.

Uma longa introdução, descrição da trajetória de Stiepan Trofímovitch, visa a alertar que aquela biografia deveria ser lida com bastante atenção, pois terminará de 
forma especial. Ao começar o romance com a biografia de um personagem que não o protagonista, o narrador destaca que a vida de um deve servir de contraponto a outra. Não só pelo fato de o mais velho ter sido tutor do mais novo, mas pelo fato de que, apesar de ambos morrerem no romance, um se despede do mundo de forma quase sublime e o outro de forma trágica.

A metáfora do ator de teatro aparece em outro momento, com aspectos negativos ainda mais destacados. No primeiro diálogo mantido entre Vierkhoviénski e Stavróguin, o niilista diz que resolveu assumir um "papel" na cidade e que ele consistia em se esconder por trás de sua verdadeira personalidade, já que "não há nada mais astuto que a própria cara, porque ninguém lhe dá crédito" (DOSTOIÉVSKI, 2004, p. 222). Diz que se portou deliberadamente de forma tola e tagarela, divulgando informações confusas sobre o passado do fidalgo para testar se o outro tinha medo de ser exposto. Como Stavróguin não saiu de casa por vários dias após a bofetada que levou de Chátov, Vierkhoviénski diz que todos o estão aguardando, o episódio havia despertado a curiosidade geral - apontando para a construção de um clima de expectativa para ele entrar em "cena": "Você agora é uma pessoa enigmática e romântica mais do que em qualquer momento - é uma posição extraordinariamente vantajosa. Chega a ser incrível o quanto todos o estão aguardando" (DOSTOIÉVSKI, 2004, p. 227).

A comparação teatral e ficcional, altamente recriminada pelo narrador em relação a Stiepan Trofímovitch, é plenamente realizada em Nikolai Stavróguin. Seja pela acentuação dos elementos visuais (beleza física, descrição das vestes) relacionados à personagem, pela constante ansiedade que a sociedade sente em vê-lo ou pela forma como o narrador decide escrever sobre os momentos que antecedem o suicídio do jovem. Vida e morte estão em consonância no registro: vivo ou morto, Stavróguin atraiu espectadores que tentaram entender seus pensamentos e ações.

\subsection{O regente e o coro ${ }^{24}$}

Em Hamlet, a violência tem frequentemente a morte como resultado. Há assassinatos realizados por ambição (segundo o fantasma, Cláudio havia matado o irmão para tornar-se rei), bem como aqueles motivados por razões sentimentais e de

\footnotetext{
${ }^{24}$ Referência à fala do personagem Lipútin, que justificou a disposição para a fofoca e eximiu-se da responsabilidade em divulgar assuntos alheios por meio da expressão: "Pois bem, o senhor fala de bisbilhotice, mas por acaso sou eu que falo muito quando toda a cidade já anda martelando e eu me limito a escutar e fazer coro? Fazer coro não é proibido" (DOSTOIÉVSKI, 2004, p. 109).
} 
honra (Hamlet mata o tio e padrasto para vingar a morte do pai). As mortes, assim como as personagens, são nobres. Para Auerbach (2011, p. 279): “Todas as personagens que Shakespeare trata trágica e sublimemente são de elevada posição social". Em $O s$ demônios, a maioria das mortes são terrenas (com exceção de Stiepan Trofímovitch, como analisado no item 2.2), movidas por fins egoístas, banais ou cruéis. A interação entre os personagens é nociva e contagiosa, cada pensamento inicial se transformando em tóxico ao ser recepcionada por outra consciência. Segundo Adam Weiner (1998, p. 94), em By Author Possessed: The Demonic Novel in Russia, uma das lições centrais de Os demônios é a dificuldade de se resistir à tentação de imitar o mal, de se guardar contra a possessão das palavras alheias. Cada personagem é o inferno do outro.

Se em A tempestade (Ato V, cena I), Próspero declara ter as sepulturas sob comando, sendo capaz de despertar aqueles que lá dormem, Stavróguin é dotado de poder contrário. Domina os vivos, apesar de aparentemente se mostrar alheio a esse efeito subjugador. Se nenhum personagem morre na peça shakespeariana, o protagonista de Os demônios manda para o cemitério todos aqueles que entram em contato com ele. Pareyson (2012, p. 52) destaca que todo contato com o fidalgo é destrutivo: "Os homens que sofreram a sua influência se perdem ou se matam ou são mortos e, em todo caso, não são nutridos, mas destruídos pelo influxo que exercita sobre eles".

Próspero leva os personagens para a ilha por meio de uma tempestade, bem como os mantém sob seus encantamentos. Apesar de não possuir poderes mágicos, Stavróguin encanta os personagens por meio de sua beleza, presença altiva e poder de influência. Sobre o domínio do jovem nos outros personagens, Pareyson (2012, p. 48) explica que os homens e mulheres o cercam, "cada um retirando do seu fascínio um motivo de enlevo e de dedicação, da riqueza da sua mente fértil e inteligente uma ideia da qual viver e se alimentar". O poder exercido nos outros, bem como as consequências de sua presença, podem ser divididos em dois grupos. O primeiro nicho de influência é marcado pelo contato com a sociedade, o que abrange aparições públicas, expectativas financeiras, enlaces românticos e sexuais, relações familiares. O segundo é marcado pela transmissão de ideias metafísicas e religiosas.

Para analisar a influência social, o trabalho se concentrará na cena em que Stavróguin reaparece na trama, não mais como lembrança do cronista, mencionada na parte "biográfica", mas como personagem que age e interage. A entrada se dá no capítulo V da Primeira Parte. Segundo o narrador, trata-se de "um dos mais notáveis dias de minha crônica. Foi um dia de surpresas, um dia de desfechos do velho e 
desencadeamento do novo, de vários esclarecimentos e de ainda mais confusão" (DOSTOIÉVSKI, 2004, p. 157). Dez personagens se encontravam reunidos na casa de Varvara Pietrovna, cada um por um motivo diferente, mas, todos eles, frutos diretos ou indiretos das ações de Stavróguin. A concentração de tantas personalidades em um espaço limitado e fechado é geralmente mais propícia para a irrupção de conflitos e intrigas. Colocar tantos personagens no mesmo lugar, em vez de fazer com que as regras de sociabilidade prosperassem, era um convite para o surgimento da verdade. Porém, há um contraste muito grande entre o trecho excessivamente narrativo dos quatro primeiros capítulos em relação ao quinto, pois todas as ações ocorrem nele. Não é coincidência que aconteçam no mesmo instante em que Stavróguin (e Piotr Vierkhoviénski) aparecem. É possível a leitura de que as brigas e confusões sucedem por causa dessas presenças. Ambos eram como ventos caóticos que irradiavam ondas de destruição.

O narrador constantemente descreve os olhares e sorrisos dos presentes e indica os gestos como forma de percepção da atmosfera da(s) cena(s). Ou seja, mais uma vez os detalhes são elementos da arena que indicam os estados psicológicos dos personagens. Exemplo: os sorrisos cruéis de Liza, a voz fraquejante de Stiepan Trofímovitch, o rubor e o silêncio de Chátov quando Varvara Pietrovna o questiona sobre Mária Lebiádkina, risos nervosos dos personagens, ruídos que anunciavam a chegada de novas pessoas, gerando expectativas. O narrador interrompe o relato dos acontecimentos para fazer um panorama das relações conturbadas entre Varvara Pietrovna e Praskóvia Ivánovna, o que também gera tensão e curiosidade diante das possíveis interações entre elas. Destaca-se que os personagens entram no recinto sempre no meio de uma discussão, quando o narrador já mudou o foco e o recém-chegado sempre se surpreende com o tom bélico que encontrava. O narrador ressalta essa impressão para destacar o surgimento de uma nova voz que, provavelmente, só pode contribuir com o clima caótico. A entrada e saída dos criados marca a mudança de foco da cena. A cena permite a leitura metonímica ${ }^{25}$ do futuro de cada um, tal como explica o narrador: "O presente momento podia ser de fato daqueles em que, como em um foco, concentra-se num átimo toda a essência da vida - de todo o passado, de todo o presente e talvez do futuro" (DOSTOIÉVSKI, 2004, p. 186). Em cada reação e contato com Stavróguin, é possível identificar pequenos anúncios de seus destinos.

\footnotetext{
${ }^{25}$ Expressão utilizada no sentido de que, a partir do fragmento, é possível pensar o todo do romance. Não faz referência à figura de linguagem, mas ao modo que Augusto Silva Junior a utiliza no seu pensamento crítico - na análise literária e/ou em pesquisas de campo (Estudos de Performance Cultural e Literatura de Campo).
} 
A chegada de Stavróguin não era esperada na ocasião, mas apenas em um mês. Quando a presença é anunciada, portanto, é recebida com surpresa. O retorno efetivo ocorreu de forma bastante anticlimática, pois "entrou voando na sala um jovem que nada tinha de Nikolai Vsievolódovitch e era completamente desconhecido" (DOSTOIÉVSKI, 2004, p. 183). Trata-se de Vierkhoviénski. A entrada verdadeira de Stavróguin não é narrada, pois quando o narrador se dá conta, ele já está dentro da sala ${ }^{26}$ : "Nikolai Vsievolódovitch já estava realmente na sala; entrou devagar e parou por um instante à porta, lançando um olhar sereno aos presentes" (DOSTOIÉVSKI, 2004, p. 185). O narrador descreve que as palavras de Vierkhoviénski "brotavam em profusão dos lábios como grãozinhos uniformes", sinalizando que as suas falas eram como sementes que visavam a colheita de um fruto, de que falava para semear discórdia. Essa posição de homem que tomava a frente da situação, que chegava imediatamente antes de Stavróguin para falar em nome dele, para criar uma expectativa e uma falsa imagem em nome do outro, é repetida ao longo do romance. Vierkhoviénski simula uma intimidade que nunca existiu entre os dois, mas Stavróguin nunca se dá o trabalho de negá-la: "Ele não esconde muita coisa de mim", afirma para o grupo (DOSTOIÉVSKI, 2004, p. 190). Essa capacidade para artimanhas, manipulações e movimentos rápidos foi utilizada pela personagem tanto no assassinato de Chátov, quanto na fuga da cidade.

O narrador admira-se com a beleza do fidalgo e aura de autossuficiência ao redor dele, mas não há interações entre os dois, o que revela uma tendência global. No romance, a pessoa com quem Stavróguin menos se relaciona é com o narrador. Eles se encontram em vários momentos, mas não há troca de palavras. Ele está presente para fornecer suporte a Stiepan Trofímovitch, o que também pode ser indicativo das motivações que o levam a escrever o relato: registrar os eventos da província por causa do "exotismo" intrínseco a eles, mas sempre, se possível, com luz favorável ao amigo. Está ali da mesma forma atrás relatada no romance: como testemunha e acompanhante secundária, mas amigável. Não se envolve diretamente e participa apenas de momentos secundários, mas importantes da trama (exemplo: convida Chátov, a pedido de Liza, para fazer parte do empreendimento editorial da moça).

Stiepan Trofímovitch está no local para resolver a questão de seu casamento com Dária Pávlovna. A motivação do enlace seria encobrir um possível envolvimento

\footnotetext{
${ }^{26}$ A cena também é descrita no presente, como se estivesse sendo narrada durante os acontecimentos. Novamente, há incongruência com a afirmativa do narrador de que a crônica foi escrita por reconstituição, pelo registro, em papel, de relatos de terceiros. A situação se complica ao se levar em consideração que o narrador estava presente no momento em questão.
} 
amoroso clandestino entre a moça e Stavróguin. Para o velho, a moça era, de fato, amante do fidalgo, impressão compartilhada - de forma velada - por todos na sala. As suspeitas foram reveladas por Vierkhoviénski, que ao chegar fez questão de ignorar os abraços efusivos do pai, estabelecendo um clima de hostilidade. A cena revela o destino de Trofímovitch na medida em que revela quão fortemente a sua existência está ligada à dos Stavróguin. Só toma parte na história do casamento por vontade de Varvara Pietrovna. Quando é acusado de nutrir desconfianças em relação às motivações do matrimônio, reage de forma paciente e altiva, o que já indica possibilidade de um futuro independente, no qual demonstraria todo o seu valor. Destaca-se o fato de ele só ter alcançado algum tipo de redenção por ter escolhido se desligar dos Stavróguin ao fim da vida, ao sair em peregrinação pela Rússia. Ainda volta a ter contato com Varvara Pietrovna, mas é ela quem decide encontrá-lo, nos momentos finais da doença dele.

Stiepan Trofímovitch cumprimenta Stavróguin, mas não recebe muita atenção, pois o rapaz estava com pressa de falar com Dária Pávlovna. A moça é descrita como uma pessoa inabalável. "Era difícil alguma coisa deixar aquela moça apreensiva por muito tempo e desnorteá-la, independente do que ela sentisse em seu íntimo" (DOSTOIÉVSKI, 2004, p. 172). Era a pessoa mais desinteressada em toda a reunião, apesar de ela ter se formado, a princípio, para decidir o seu futuro conjugal. A mesma parcimônia e tranquilidade que ela demonstra no momento é correspondente ao papel de segurança que ela ocupava na vida de Stavróguin. Havia sido acusada de roubar uma quantia financeira ao fazer uma entrega a pedido do fidalgo, mas se defende, o que já a localiza como realizadora de missões para o jovem. Quando comunica à protegida que ela está livre de qualquer suspeita, Varvara Pietrovna demonstra ter bastante consciência de ter uma audiência e dirige a mensagem mais para os ouvintes do que para a moça. Toda a cena demonstra que Dária Pávlovna era tão desapegada da vida quanto o próprio Stavróguin, a não ser quando o assunto era ele mesmo. Diante da aparição do jovem, ela estremece e fica vermelha, mas ainda assim é a preferida de Stavróguin para conversar.

O principal diálogo entre eles acontece no Capítulo III da segunda parte do romance ("O duelo"). A conversa ocorre em tom sombrio e é prenúncio de morte, pois gira em torno das últimas questões. Stavróguin diz à moça que há muito tempo vinha planejando romper com ela. Ela concorda e diz a ele que agora só resta esperar pelo "fim". Destaca-se o fato de que eles nunca falam abertamente sobre qual é o "último fim" que o espera. A informação só é revelada na carta escrita por Stavróguin ao fim do romance, ou seja, ele pretendia sair da Rússia e isolar-se em um lugar remoto, Dária o 
acompanharia. Stavróguin afirma: "Parece que realmente vou chamá-la para o último fim, como você diz, e você virá apesar do seu juízo. Por que você mesma se destrói?” (DOSTOIÉVSKI, 2004, p. 290). Stavróguin aponta o interesse mórbido de Dária Pávlovna em relação a ele e compara a moça a "essas velhotas piedosas, que andam de enterro em enterro, preferem uns cadáveres por julgá-los mais bonitos que outros" (DOSTOIÉVSKI, 2004, p. 290). Ao pensar na analogia em sentido amplo, portanto, é possível notar que ele mesmo se coloca na posição de defunto velado. O sepultamento simbólico do vivo não ocorre, pois eles não chegam a se mudar para o Cantão de Uri devido ao suicídio de Stavróguin. Destaca-se que a moça é uma das pessoas presentes à descoberta do cadáver, o que possibilita que, de certo modo, ela cumprisse a missão a que se propôs: se não pôde "velar" o vivo, acompanhou os procedimentos finais relacionados ao corpo morto. $\mathrm{O}$ desinteresse em relação à possibilidade de se casar revela não só a condição servil perante Varvara Pietrovna, mas também o quanto o destino girava em torno de Stavróguin e como o resto lhe é indiferente, já que largaria tudo para segui-lo até o abismo (metafórico e geográfico). A disposição de samaritana não deixa de ter nuances suicidas, pois ela abre mão, pelo menos simbolicamente, da própria vida, para ser a "enfermeira" dos últimos momentos do fidalgo.

Outra pessoa presente à cena do suicídio de Stavróguin é Varvara Pietrovna. A primeira cena entre mãe e filho é correspondente da última, pois em ambas há tensão e o caráter de excepcionalidade está marcado. No encontro, como na despedida, a mãe está "toda mergulhada na pergunta, e todo o seu aspecto dizia que se transcorresse mais um instante ela não suportaria a incerteza" (DOSTOIÉVSKI, 2004, p. 187). A interrogação da primeira cena é pontual, enquanto a segunda é metafórica. Em ambos os casos ela não sabe o que esperar da resposta/atitude do jovem. Ao vê-lo em seu salão, a reação de Varvara é impetuosa e indiscreta, o que destoa do seu constante esforço de agir de acordo com as regras sociais. Pergunta, diante de todos, se ele está casado com a coxa, o que ele não responde. Em vez disso, a cumprimenta com sorriso indulgente: "Era tão forte e insuperável a influência que ele sempre exercera sobre a mãe, que nem neste momento ela ousou retirar a mão. Apenas olhava para ele, toda mergulhada na pergunta” (DOSTOIÉVSKI, 2004, p. 187). O gesto é indicativo de quão frágil era a relação dos dois, que se resume na criação de expectativas da mãe em relação ao filho e, por parte dele, na quebra de todas elas, seja enquanto vivo, seja na hora da morte.

Durante a cena, ela diz que se Horácio ou Ofélia estivessem ao lado de Stavróguin ele se curaria do demônio da ironia. Ou seja, alguém para contar a sua 
história após a morte (o que ele possui) e uma mulher disposta a fins trágicos por sua causa (o que também há). Em princípio, parecia que Dária Pávlovna estava mais próxima da figura de Ofélia, mas ao longo do romance, quem passa a ocupar essa posição foi Liza. É ela quem passa por um processo de autodestruição, que é indireto (à semelhança do que ocorre com a personagem de Shakespeare), pois ela vai até o incêndio (rio), mas é o povo que a pisoteia. A água metafórica (fogo) a engole, portanto, quem é responsável pela morte?, perguntariam os coveiros de Hamlet, sem resposta. Assim como a personagem de Shakespeare, Liza enlouquece antes da morte.

A decisão do filho de se suicidar tem consequências mortais na narrativa de Varvara Pietrovna, pois trata-se da última vez em que ela é mencionada no romance. O narrador enfatizou o movimento de subida da mulher para o sótão do ato final, como se fosse ela a pessoa a caminhar em direção à morte: "Teriam de subir quase por cima do telhado, por uma escada de madeira longa, muito estreita e terrivelmente íngreme. Lá também havia um quartinho" (DOSTOIÉVSKI, 2004, p. 653). O anúncio do pequeno cômodo fornece paralelo às modificações recentes sofridas pelo cenário, o que sugere mudança de destino: "A porta do sótão, que estava sempre fechada, agora estava escancarada" (DOSTOIÉVSKI, 2004, p. 653). A descrição sugere que aquele que dispusesse a atravessar o portal recém-aberto para o desconhecido encontraria claustrofobia e confinamento. Todos esses elementos são pavorosos a um vivo, pois remetem ao sepultamento do corpo no caixão, o trespasse para o undiscovered country do qual ninguém jamais retorna. Apesar de amedrontada, a fidalga vai até o sótão, ou melhor, "ascendeu" até ele: o movimento de subida que faz para chegar até lá ressalta a sua queda posterior. "Varvara Pietrovna precipitou-se escada acima; Dacha, atrás dela; porém, mal entrou no sótão, deu um grito e desmaiou" (DOSTOIÉVSKI, 2004, p. 653). Perda dos sentidos e escuridão, é o que a mulher encontra ao descobrir o suicídio, o que sugere que ela morre junto com o filho, pois a vida dela perde o sentido: "Em minhas vidas pessoas nascem, passam e morrem, e a vida-morte delas é frequentemente o acontecimento mais importante da minha vida, que lhe determina a existência" (BAKHTIN, 2011, p. 96). Fica elucidado o ponto de vista segundo o qual a morte de um é acontecimento na vida de outro. A mãe desmaia como quem adentra o inferno, pois acabava ali qualquer possibilidade de esperança. Nada mais é dito sobre ela.

Os Lebiádkin também estão presentes na casa de Varvara Pietrovna. São os elementos escandalosos da cena, dois personagens excêntricos que em condições normais a sociedade faria de tudo para esconder, mas que dada a concentração de 
situações da cena, ao clima de liberdade criado pela excepcionalidade do evento, há permissão para que estejam presentes. Em determinando momento, o capitão oferece dinheiro à dona da casa, o que tem efeito desestruturador. Faz questão de manter o seu segredo diante dela. Também funcionam como elemento de contraste para Stavróguin, que leva os outros personagens e leitores a se questionarem por que um rapaz da sociedade teria se misturado com eles. Segundo Liputin, em diálogo com Stiepan Trofímovitch, no capítulo IV da primeira parte (denominado "A coxa"), é o capitão quem primeiro identifica em Stavróguin uma sábia serpente, o que também é um indicativo de sua habilidade de insuflar os outros de forma negativa. Segundo Frank (2003, p. 625), o capitão seria uma prévia de Dmitri Karamázov: "Ele é também uma versão pobre e descuidada do extremo alcance das possibilidades - um gosto, de um lado, pela poesia e pela beleza e, de outro, pela bestialidade e pela crueldade - numa guerra de uma com a outra em Stavróguin no plano da tragédia".

A presença dos Lebiádkin reforça o que Pareyson (2012) percebeu em Stavróguin, ou seja, um contexto de farsa relacionado ao caráter experimental de suas ações. A impostura, causada pela incapacidade de agir com sinceridade, é perceptível pelos puros de coração, como ocorreu com Lebiádkina. Após cinco anos aguardando o retorno do esposo, a mulher semi-louca reencontra Stavróguin na reunião, mas não o reconhece. Ela julga estar diante de um mau ator, de um impostor que, por algum motivo, teria matado o seu objeto de amor e tomado o lugar dele: "Tu te pareces, pareces muito, talvez seja um parente dele - gente astuta! Só que o meu é um falcão luminoso e um príncipe, enquanto tu és um mocho e vendeiro!" (DOSTOIÉVSKI, 2004, p. 277). Frank (2003, p. 631) a descreve como "infantil e mentalmente fraca, incapaz de distinguir entre a realidade objetiva e seus sonhos e desejos, mesmo assim ela enxerga através da 'máscara' de Stavróguin com uma clarividência que lembra o príncipe Míchkin e prenuncia o padre Zóssima”. Lebiádkina não associa Stavróguin ao homem com quem ela havia casado, pois o seu 'príncipe' jamais sentiria vergonha dela em frente às pessoas da sociedade. “O meu se quiser fará uma reverência até a Deus, se não quiser não fará [...]" (DOSTOIÉVSKI, 2004, p. 277). Chama-o de "Gríchka Otrepiev". Segundo o pesquisador (2003, p. 632), ao chamá-lo assim, Lebiádkina confere ao homem uma dimensão histórico-simbólica. "Ele não é o 'Príncipe', não é o genuíno Senhor e Dominador da Rússia, mas apenas Grichka Otrépiev, 'amaldiçoado em sete catedrais', o ímpio e sacrílego ‘impostor' e ‘falso pretendente'”. A acusação antecipa os 
planos de Vierkhoviénski de lançá-lo como Ivan Czariévitch, ou seja, como substituto do czar quando as bases da sociedade forem destruídas.

Apesar de ter permanecido pouco tempo no recinto, a moça demonstra lucidez o suficiente para perceber que havia muitos conflitos subentendidos e que a sala parecia um vulcão prestes a entrar em atividade. Quando Stavróguin vai visitá-la, ela diz: “Todos estão conspirando - será que ele também? Será que ele também traiu?" (DOSTOIÉVSKI, 2004, p. 274). Ela destaca, portanto, o aspecto de arena do romance, no qual um é demônio do outro. Trata-se de outra cena visual, pois a mulher pede que o fidalgo saia e entre de novo de seu quarto, para que pudesse analisar melhor os próprios sentimentos ao perceber-se diante dele. Stavróguin se nega a fazê-lo, o que faz com que ela reafirme não acreditar na farsa desempenhada pelo "usurpador", que não poderia ser o seu "príncipe", pois carregava uma faca. Os irmãos Lebiádkin têm um fim terrível, cuja responsabilidade é de Stavróguin. Ao sair da casa dos Lebiádkin, depois de ter sido chamado de farsante, encontra-se com o ex-prisioneiro Fiédka, que o aguardava. Ordena que o fugitivo se livre da faca e, diante da insistência do homem, que implora por três rublos, cede. "Nikolai Stavróguin deu uma gargalhada alta e, tirando do bolso o moedeiro em que havia uns cinquenta rublos em notas miúdas, lançou-lhe uma moeda do maço, depois outra, uma terceira, uma quarta" (DOSTOIÉVSKI, 2004, p. 280). Segundo Frank (2003, p. 632), “com esse gesto, Stavróguin consente em silêncio no assassinato dos Lebiádkin, submetendo-se mais uma vez à tentação do mal".

O assassinato deles é forjado de forma a parecer acidente. Há um incêndio no povoado de Zariétchie, mas o fogo não queima a casa dos Lebiádkin com força o suficiente para destruí-la, o que permite que as investigações descubram que, na realidade, a morte deles se deu por esfaqueamento. Aparentemente, haviam sido roubados, mas só dinheiro havia sido levado, os objetos da casa permaneceram intactos. Por causa da confusão, descobriu-se que "aquela casa fora alugada para o capitão e a irmã pelo próprio senhor Stavróguin, Nikolai Vsievolódovitch, o filhinho da generala Stavróguina, que ele mesmo procurara o dono para alugá-la, persuadira-o demoradamente porque o dono não queria alugá-la" (DOSTOIÉVSKI, 2004, p. 505).

Outros presentes no salão de Varvara Pietrovna são Lizavieta Nikolaievna, a mãe da moça e Mavrikii Nikolaievitch. A jovem havia presenciado o encontro entre Varvara Pietrovna e Mária Lebiádkina na igreja e, movida pela curiosidade, as acompanha até a casa. A senhora acusa a dona de casa de ter envolvido Liza na sua confusão familiar ao permitir que a filha andasse ao lado da coxa. Sobre Mavrikii, é 
importante destacar que há apenas uma interação de fato entre o rapaz e o protagonista no romance, mas o diálogo que mantêm é profético. O noivo de Liza pede que ele se case com a moça, já que, apesar de compromissada, ela jamais hesitaria em fugir com Stavróguin: "Debaixo daquele ódio constante, sincero e mais completo pelo senhor, a cada instante resplandece o amor e... a loucura... o amor mais sincero e desmedido" (DOSTOIÉVSKI, 2004, p. 371). A profecia se concretiza. Apesar do compromisso firmado, Liza foge com Stavróguin. A cena que retratou o desenrolar da evasão é a última de Stavróguin antes do suicídio (bem como das mortes de Kiríllov e Chátov) e está localizada no capítulo III da terceira parte ("Romance terminado"). Ou seja, o rompimento amoroso dos jovens aponta fim da narrativa. Da fuga, decorre a morte (simbólica e física) de Liza. Quando os dois conversam após o ato amoroso, ela diz a Stavróguin que sabia que não era amada e que seria abandonada. "Está lembrado de que ontem, ao entrar, eu me apresentei como morta? [...] Vivi minha hora no mundo e basta." Liza compara-se a uma vela que se queimou, diz que havia planejado a própria vida para viver aquela noite com ele e não se arrepende.

É importante destacar que as nuances suicidas da relação de Liza com Stavróguin já haviam sido destacadas em diálogo localizado no capítulo $\mathrm{X}$ da segunda parte do romance (“Os filibusteiros - Manhã fatal”). No salão de Yúlia Mikháilovna, Liza declara: “- Nikolai Vsievolódovitch, um certo capitão, que se diz seu parente, irmão da sua mulher e de sobrenome Lebiádkin, continua a me escrever cartas indecentes e nelas faz queixas contra você, propondo-me revelar uns certos segredos a seu respeito" (DOSTOIÉVSKI, 2004, p. 445). A violência das palavras é tanta que o narrador afirma: "Parecia com aquela situação em que, de cenho franzido, uma pessoa se atira de um telhado" (DOSTOIÉVSKI, 2004, p. 445). Morre brutalmente porque vai até o local do incêndio dos Lebiádkin. Acusada de ser concubina de Stavróguin e cúmplice do assassinato, é agredida e pisoteada.

$\mathrm{Na}$ reunião ocorre o primeiro contato entre Stavróguin e Chátov. O jovem permanece quieto em meio à agitação, mas se faz notar de forma abrupta. "Súbito Chátov sacudiu o braço longo e pesado e lhe bateu com toda força na face. Nikolai Vsievolódovitch balançou fortemente no lugar" (DOSTOIÉVSKI, 2004, p. 206). Stavróguin não revida o golpe, o que assusta o narrador, já que o homem não conhecia o medo e era dotado de "uma raiva sensata, fria e tranquila, a mais repugnante que pode haver" (DOSTOIÉVSKI, 2004, p. 207). A bofetada que não é rebatida indica algum tipo de cumplicidade entre os dois, pois o fildalgo não se deixaria ofender por qualquer um. 
Tal qual a presente cena, as interações e os diálogos entre eles são intensos e cheios de arrebatamento emocional por parte de Chátov. Há muito de performático na conduta da personagem, pois ela está sempre marcada por explosões de temperamento, palavras furiosas, saídas intempestivas. O ex-servo faz questão de marcar independência em relação às outras pessoas. $\mathrm{O}$ jovem também apresenta mudanças constantes de humor, fala olhando para baixo, anda sempre com o cabelo eriçado, elemento visual que remete à sua personalidade irascível. Ao fim do romance, é brutalmente assassinado. Enquanto vivo, fez parte do grupo de personagens que manteve relações dialógicas metafísicas com Stavróguin, juntamente com Piotr Vierkhoviénski e Kiríllov.

Segundo Shneidman (1984, p. 28), no centro da ficção dostoievskiana póssiberiana estão personagens fortes que dominam outros. O pesquisador cita Foma Opínski, de A aldeia de Stiepantchikovo, e o príncipe Valkóvski, de Humilhados e ofendidos, como exemplos. O próprio título do romance, a combinação de dois particípios, já sugere um mal infligido por uma força subjugadora. Em Os demônios, a figura de dominação máxima é Stavróguin. Sobre o poder de influência da personagem, Pareyson (2012, p. 34) escreve: "Da plenitude de sua criatividade, posta sob o signo da destruição, surgem sempre novas ideias, das quais os seus amigos vivem mais e mais transportados, sempre, porém, culminando no naufrágio, sem que, por isso, ele sinta [...] a mínima responsabilidade".

Stavróguin é a sábia serpente cuja presença causa discórdia e morte. Ou seja, como o caminho de Stavróguin é de pura destruição, um personagem acaba matando e "suicidando o outro", arrastando uns aos outros para o abismo, pois a morte é acontecimento em cadeia. A experiência do inferno é guiada e depende diretamente de cada passo da travessia. 


\title{
CAPÍTULO 4: DIALOGISMO DA AUTODESTRUIÇÃO: TRÊS VOZES DISSONANTES
}

\author{
Um demônio, um demônio de nascença \\ cuja natureza nenhum ensinamento consegue alterar; \\ nele todos os meus esforços de tratá-lo com humanidade foram \\ para nada: \\ tudo perdido, tudo completamente perdido. \\ $E$, à medida que envelhece, seu corpo torna-se mais feio, \\ e sua mente se corrompe. \\ Eu os atormentarei, a todos, \\ até que estejam gritando, urrando, urrando, rugindo, uivando. \\ William Shakespeare, A tempestade
}

\subsection{Polifonia e multiplicidade de vozes}

Dostoiévski leva o preceito de polifonia ao extremo na composição do protagonista de Os demônios. Bakhtin destaca que "em Os demônios não há uma só ideia que não encontre resposta dialógica na consciência de Stavróguin" (BAKHTIN, 1997, p. 73). A ressonância de características hamletianas em Stavróguin, bem como as contradições psicológicas, fazem dele um personagem constituído por multiplicidade de vozes. Ele é polifônico, tanto em aspectos internos, ligados ao pensamento, como à forma de expressá-los. Os personagens fragmentados ${ }^{27}$ são comuns na obra de Dostoiévski, como por exemplo: Goliádkin, de $O$ duplo; o homem das Memórias do subsolo; Raskólnikov, de Crime e castigo. É possível refletir sobre eles por meio de Os irmãos Karamázov. Aliócha diz frase sobre Dmitri (também um fragmentado) que poderia ser usada para descrever os homens do autor e é fundamental para compreender o motivo que levou Stavróguin ao suicídio: "Há nele uma ideia grande e não resolvida. Ele é daqueles que não precisam de milhões, mas precisam resolver uma ideia" (DOSTOIÉVSKI, 2008, p. 127). Stavróguin nunca atingiu essa resolução. A trajetória de Stavróguin é a de um morto-vivo: a de um homem que fragmentou o discurso em diálogos de morte. À medida em que escuta as próprias ideias proferidas por outras

\footnotetext{
27 A fragmentação do sujeito está no cerne da Modernidade e já estava problematizada em Shakespeare (assim como em Rabelais e Sterne, por exemplo). Segundo Bloom (2014), a imagem-chave de Hamlet é a do príncipe segurando o crânio de Yorick e fazendo a ele perguntas cruéis e irrespondíveis. Em $O s$ demônios, os questionamentos vitais de Stavróguin foram feitos também em voz alta, não mais para os ossos de uma pessoa morta, mas para pessoas vivas que foram conduzidas para mais perto da morte ao ouvi-lo e se deixarem convencer.
} 
pessoas e percebe o quão distante está dos posicionamentos que adotou no passado, vai se desligando do mundo. Perde um pedaço de si a cada passo que dá, a cada momento que tem oportunidade de se conectar com uma crença maior, sem conseguir dar o salto.

A autodestruição do fidalgo ocorre por etapas, numa escala de descrença que pode ser percebida pela influência que exerceu em outras personagens. A descida completa ao seu inferno pessoal se dá por meio de três patamares principais de contato dialógico, anteriores à concretização do ato, ou seja, o suicídio: 1) Em Chátov, nota-se a porta do inferno de Stavróguin: apresenta-se uma possibilidade de ressurreição moral cujo caminho é o amor (a Deus, ao povo, ao próximo, à família), mas que é rechaçada de forma violenta com mergulho mortal em um rio de sangue ${ }^{28}$; 2) Com Vierkhoviénski, a queda livre: elucida-se como palavras e atos possuem consequências nas vidas alheias. Ao rumar em direção ao abismo, quem nega Deus ${ }^{29}$ e carrega outros consigo decai com maior velocidade; 3) Com Kiríllov, a proximidade do chão: o ensimesmamento daquele que busca substituir Deus ao dar ouvidos à sábia serpente significa a perda irrevogável de qualquer possibilidade de redenção e de chegar ao paraíso $^{30}$; 4) O suicídio de Stavróguin: o corpo não atinge o chão e paira metaforicamente sobre o mundo, pois é morte que não gera vida, é semente que não dá frutos, é árvore retorcida ${ }^{31}$ de cujos galhos escorre dor, sangue e mau exemplo.

A descida do protagonista de Os demônios é coletiva na medida em que ele precisa interagir com três outras consciências para tentar compreender a própria:

\footnotetext{
Cada um segue a Stavróguin como a um mestre, interpretando-lhe a voz como integral e segura. Todos pensam que ele fala com eles como um preceptor com um pupilo. Em realidade, ele os torna participantes do seu diálogo sem saída, no qual convence a si próprio e não a eles. Agora Stavróguin escuta de cada um deles as suas próprias palavras, pronunciadas, porém, com um firme acento monologado. Ele mesmo pode repetir agora essas palavras apenas com acento de zombaria e não de convicção. Não conseguiu convencer a si mesmo de nada e ouve com dificuldade as pessoas
}

\footnotetext{
${ }^{28}$ Em A Divina Comédia, de Dante (Inferno, Canto XIII), aqueles que atentam contra o próximo por meio de violência são condenados a um banho eterno em rio com sangue daqueles que feriram. A quantidade de membros imersos é proporcional à gravidade do mal que causaram. O trabalho defende que, ao não evitar a morte de Chátov, Stavróguin suja as mãos de sangue com essa morte e inicia o seu processo de autodestruição.

${ }^{29}$ No Canto XIV do Inferno de Dante, aqueles que comentem violência contra Deus são alocados em um deserto no qual há chuva de fogo. Os blasfemos, como é o caso de Vierkhoviénski, são condenados ao sofrimento mais profundo.

${ }^{30}$ Referência ao momento em que Adão e Eva, insuflados pela serpente, comem o fruto proibido na intenção de obterem todo o conhecimento do bem e do mal (Gênesis 2:9, 3:2).

${ }^{31}$ No vale dos suicidas de A Divina Comédia de Dante (Inferno, Canto XIII), o castigo daqueles que retiraram as próprias vidas é a transformação em semente e, posteriormente, em árvores tortas com espinhos venenosos.
} 
por ele convencidas. Nesta base constroem-se os diálogos de Stavróguin com todos os seus três seguidores (BAKHTIN, 2002, p. 266).

Stavróguin se surpreendia ao ouvir as próprias ideias em vozes alheias, primeiramente por não se enxergar em nenhum dos pontos de vista e devido ao grau de fanatismo adotado pelos outros jovens. Segundo Bakhtin (2011), o importante no contato dialógico é que os falantes e atuantes permaneçam outros numa interação. Se há fusão total, não há troca, mas apenas mera replicação de um dos sujeitos. Portanto, o choque do Stavróguin ouvinte é profundo, pois há duplo reconhecimento: de que nunca acreditou nas ideias que proclamava, de que a pessoa a sua frente é um ser pleno, capaz de sentimentos verdadeiros. Ao falar, os pupilos revelaram que a catequização foi enriquecida ao adquirir traços pessoais de cada um. Bakhtin explica o fenômeno a partir do fato de que, quando alguém sente simpatia pela vida do outro, um impulso inicial se transforma e se complexifica. "A eficácia do acontecimento não está na fusão de todos em um todo mas na tensão da minha distância e da minha imiscibilidade, no uso do meu lugar único fora dos outros indivíduos" (BAKHTIN, 2011, p. 80).

Uma ideia dialogada pode ser muito bem compreendida e ainda assim transformada, o que possibilita a leitura de que há níveis de profundidade no inferno pessoal do protagonista. Os quatro demônios da arena infernizam-se. Sobre a influência ativa e maligna do romance, no artigo "Sempre Dostoiévski", Augusto Meyer afirma que o tema central deveria ser a atividade revolucionária dos jovens russos, mas que ela “empalidece diante da vida eletrizante que agita alguns tipos formidáveis de primeiro plano, Stavróguin, Kiríllov, Chátov" e que estes personagens "acabam desbancando Piotr Stiepánovitch, herói da história, porque é em torno deles que reaparece o irreprimível Leitmotiv do solilóquio metafísico" (MEYER, 1986, p. 375). Perdidas em seus mundos interiores, elas formam uma "espécie de pare-gato" demoníaco (MEYER, 1986, p. 375). O inferno são eus em contato com outros ${ }^{32}$.

Segundo Bakhtin (2002, p. 77), “o herói dostoievskiano não apenas é um discurso sobre si mesmo, mas também um discurso sobre o mundo: ele não é apenas um ser consciente, é um ideólogo". Ao tentar compreender o próprio discurso, Stavróguin o fragmenta em três vozes, como uma espécie de coral infernal na qual o maestro é o que

\footnotetext{
${ }^{32}$ Breve referência a Sartre que, em $O$ ser e o nada, escreveu a famosa frase: "O inferno são os outros". O texto também fala sobre a liberdade radical do homem, tema bastante explorado por Dostoiévski, principalmente na questão de exercer ou não o poder de tirar a própria vida. O escritor francês também defendia a ideia de que a existência precede a essência, e por um ponto de vista DostoievskianoBakhtiniano é possível considerar que a essência do ser humano é o resultado de relações dialógica travadas com o outro.
} 
menos compreende a melodia conduzida. Kiríllov, Chátov e Vierkhoviénski entraram em contato tão íntimo com as dúvidas e hipóteses de Stavróguin, que foram reestruturados por elas. São estágios da consciência, progressões da incerteza, ecos dos inúmeros discursos abandonados pelo protagonista em algum momento. Para tentar compreender o protagonista de Os demônios, é importante considerar os três, pois é sempre neles que há tomada de posições. Nos “pupilos” de Stavróguin, há a passagem do discurso polifônico para o universo monológico, no qual "a ideia é afirmada ou negada" (BAKHTIN, 2002, p. 79). Os três assumem atitudes concretas diante da possibilidade da existência de Deus e por causa delas, são relacionados ao tema da morte de forma específica.

Em Os demônios, há interação entre os personagens e as consciências deles, mas elas não são dominadas, nem são objeto de completa dominação uma das outras, o que explica que a apreensão das falas de Stavróguin é sempre deturpação do pensamento original. Por causa desse traço da poética do escritor russo, as principais polêmicas da sociedade russa do século XIX (como por exemplo o positivismo, o eslavofilismo, as teorias socialistas etc.) aparecem sob nova roupagem ao serem dialogadas: a sábia serpente os leva, com discurso envolvente, ao fruto da decadência e morte.

\subsection{Chátov e a ressurreição interceptada}

Chátov é participante essencial da arena de Stavróguin. Mostra o valor pessoal e a força da paixão de suas concepções por meio do discurso. Primeiramente, diante de Stavróguin. Antigo servo de Varvara Pietrovna, mantém dicotômica devoção ao fidalgo. Admira-o pela inteligência, mas o condena por ter manipulado seus sentimentos ao lhe transmitir crenças nas quais não acredita. Afirma a própria individualidade no romance e na vida do ex-mestre ao expressar todo o seu descontentamento, ou seja, a utilização da palavra é gesto de revolta. Sobre essa possibilidade de intervenção ativa, associada à interioridade de uma pessoa, Bakhtin discorre: "De dentro da minha consciência participante da existência, o mundo é objeto do ato, do ato-pensamento, do atosentimento, do ato-palavra, do ato-ação" (BAKHTIN, 2011, p. 89).

Foi casado, mas não vivia mais com a esposa (que após o fim do enlace envolveu-se sexualmente com Stavróguin). O poder do fidalgo sobre o jovem é mencionado desde a primeira vez que o narrador o cita na narrativa, mas de forma velada. "No estrangeiro Chátov mudou radicalmente algumas de suas antigas 
convicções socialistas e pulou para o extremo oposto" (DOSTOIÉVSKI, 2004, p. 39). O narrador o descreve como um ser comprometido com as convicções, a ponto de se deixar esmagar por elas. Nesse sentido, Camus (2010) escreveu: "Um homem é sempre vítima de suas verdades. Uma vez que as reconhece é capaz de se desfazer delas. Precisa pagar um preço". Para o jovem, o custo de suas crenças foi bastante caro: a própria vida. A causa da morte foi o contato com o "mestre". No romance, o primeiro encontro entre eles ocorre na cena da bofetada. Não há troca de palavras. No segundo, travam longo diálogo, no qual o "pupilo" diz que o golpeou porque, ao contrário dos outros, sabia que o fildalgo era casado com Mária Lebiádkina. "Foi por sua queda... pela mentira. Não me aproximei com o intuito de castigá-lo; enquanto me aproximava não sabia que ia dar o soco... Fiz aquilo pelo muito que você tinha significado em minha vida" (DOSTOIÉVSKI, 2004, p. 242). A dívida que o ex-servo tem com o fidalgo não é apenas espiritual e moral, mas também financeira. Só conseguiu sair da América graças ao dinheiro emprestado por Stavróguin.

Chátov diz que esperou por Stavróguin por dois anos e pede que o outro conceda a ele dez minutos de conversa. "Deixe de lado o seu tom e assuma um tom humano. Fale ao menos uma vez na vida com voz humana. [...] Compreenda que deve me desculpar por aquele soco na cara, já pelo simples fato de que lhe dei a oportunidade de conhecer aí a sua força ilimitada...” (DOSTOIÉVSKI, 2004, p. 247). A ansiedade dele se assemelha à de Aliócha para para travar relações com Ivan, em Os irmãos Karamázov. A conversa do romance final de Dostoiévski também é importantíssima para o todo da obra, pois é nela que é narrada a "Lenda do Grande Inquisidor". Em ambas as comunicações, o mesmo tema: a existência de Deus. "Tu mesmo, por que passaste três meses me olhando com expectativa? Para me interrogar: 'Então, crês ou não crês absolutamente?' - porque nisso se resume o sentido desses três meses de teus olhares dirigidos a mim, Alieksiêi Fiódorovitch, não é isso?” (DOSTOIÉVSKI, 2008, p. 322). É possível pensar um romance por meio do outro pois, segundo Camus (2010, p. 125), “Os Karamázov respondem aos Possessos. E trata-se mesmo de uma conclusão".

Em Os irmãos Karamázov o que ocorre é uma exposição pacífica e aprofundada do mais velho para o mais novo, que a recebe com todo o interesse. Em Os demônios o tom é de acerto de contas. Há semelhança entre as duas conferências, pois as duas contam com o recurso de um sujeito que externaliza um diálogo interior. No romance da maturidade, ao falar, Ivan não se comunica com o irmão mais novo, mas consigo mesmo. Quando escreve um poema no qual o chefe da igreja e Deus se encontram, o 
jovem coloca os próprios questionamentos metafísicos na fala provocadora e terrível do suposto homem de fé. No cerne da questão, as tentações do Diabo diante de Cristo.

Stavróguin catequiza Chátov para tentar entender as próprias dúvidas religiosas: "Ao persuadi-lo, talvez me preocupasse ainda mais comigo do que com você", nas palavras do próprio (DOSTOIÉVSKI, 2004, p. 248). O romance não transcreve esse primeiro contato, apenas desdobramentos dele, por meio de uma segunda conversa, que gira em torno do papel messiânico da Rússia, povo que teria a missão de restaurar o mundo por meio da "nova palavra", da fé em um Deus renovado. O foco da conferência, porém, é o desgosto de Chátov por ter sido cobaia dos experimentos ideológicos de Stavrógin, expresso em berros. O levantar da voz demonstra que ele havia começado a superar a influência que o fidalgo exerce em sua vida e que se houver afastamento completo, há possibilidade de salvação para o ex-servo.

Chátov associa o discurso à possibilidade de transformação moral. Quando Stavróguin reconheceu o tema como sendo a conclusão da conversa que haviam tido, diz: “A frase é inteiramente sua e não minha. [...] Não houve nenhuma 'nossa' conversa: houve um mestre que conhecia as palavras de alcance imenso, e havia um discípulo que ressuscitara dos mortos. Eu sou aquele discípulo e você, o mestre" (DOSTOIÉVSKI, 2004, p. 248). O fidalgo lembra ao ex-servo que ele havia ingressado na sociedade revolucionária após a conversa, portanto, a influência não poderia ter sido tão forte, ao que Chátov discorda. "É difícil trocar de deuses. Naquele momento não acreditei em você porque não queria acreditar, e me agarrei pela última vez àquela cloaca... mas a semente permaneceu e cresceu" (DOSTOIÉVSKI, 2004, p. 248). Mais uma vez a palavra é afirmada como algo que dá ou subtrai vida. Destaca-se a consciência do pupilo de ter sido arrastado para o inferno do outro, pois havia percebido que o mestre não acreditava verdadeiramente em nada. "Soube por ele que enquanto você implantava Deus e a pátria em meu coração, exatamente ao mesmo tempo [...] você envenenou o coração daquele infeliz, do maníaco do Kiríllov... você implantou nele a mentira e a calúnia e levou a razão dele ao delírio...” (DOSTOIÉVSKI, 2004, p. 248).

Segundo Bakhtin (2011, p. 271), um ouvinte, "ao perceber e compreender o significado (linguístico) do discurso, ocupa simultaneamente em relação a ele uma ativa posição responsiva: concorda ou discorda dele (total ou parcialmente), completa-o, aplica-o, prepara-se para usá-lo etc.”. O fanatismo com que Chátov absorve as ideias do fidalgo (em relação às considerações sobre o povo russo) demonstra que a recepção foi criativa e construtiva, ou seja, não houve fusão completa com o discurso inicial, mas 
deformação. Stavróguin percebeu o fenômeno: "Você as aceitou [as palavras] e fervorosamente as modificou sem se dar conta" (DOSTOIÉVSKI, 2004, p. 251).

O aspecto de arena é um elemento marcante do diálogo, pois Chátov adota uma postura combativa em relação ao outro. Grita e argumenta como se estivesse lutando para salvar a própria alma no juízo final, uma possível leitura metafórica da cena. Quando Stavróguin o questiona se acredita em Deus, o jovem responde: "Eu hei de crer em Deus [...] Você é o único que pode carregar essa bandeira" (DOSTOIÉVSKI, 2004, p. 253), o que demonstra que nesse ponto do romance a fé dele não é verdadeira e que ele havia rebaixado Deus a um atributo do povo em suas explanações. O furor de sua fala, portanto, demonstra tanto a angústia de ter sido enganado, como a reprovação, autodirigida e velada, em relação ao fato de ele mesmo não crer verdadeiramente no Criador, apesar de desejá-lo ardentemente. Essa característica de Chátov pode lançar luz ao motivo que o levou a se apegar tão profundamente aos ensinamentos de Stavróguin. Segundo Camus: "De fato, o que aproxima as inteligências são menos as conclusões idênticas do que as contradições que têm em comum" (2010, p. 111). Ou seja, ambos estão longe de uma crença verdadeira, apesar de tê-la buscado ardentemente.

O poder de persuasão de Stavróguin é tão forte que inspira idolatria. A tendência fica explicitada quando o ex-servo declara estar condenado a acreditar nele para sempre. "Não consigo arrancá-lo do meu coração, Nikolai Stavróguin!” (DOSTOIÉVSKI, 2004, p. 255). Stavróguin se espanta com essa e outras declarações de Chátov, pois não leva em consideração a responsabilidade que as palavras-ato lançadas na arena têm na vida alheia: "Por que esse negócio de estarem sempre me impondo alguma bandeira? Piotr Vierkhoviénski também está convencido de que eu poderia 'levantar a bandeira deles"” (DOSTOIÉVSKI, 2004, p. 253). Ou seja, apesar de saber que está imerso em um inferno de descrença, ainda não havia percebido que carregava os outros consigo.

Chátov é uma espécie de correspondente de Horácio para Stavróguin, pois foi ele quem o avisou que havia algo de podre na Dinamarca, ou seja, as relações perniciosas da arena do fidalgo, cuja base era a descrença em Deus. Vem dele a sugestão de que Stavróguin visite Tíkhon, ex-bispo ortodoxo, numa indicação de que o ex-servo, ao lutar pela salvação do ex-mestre, também busca o próprio renascimento espiritual. Até o fim do romance, o rapaz faz de tudo para se desligar da sociedade radical com a qual está envolvido, mas acaba assassinado por membros dela. A esposa, de quem está separado, retorna ao lar, grávida de um filho de Stavróguin. Chátov fica extasiado diante do milagre da vida e imediatamente toma a criança como filho. "Eram 
duas pessoas, e de repente uma terceira, um espírito novo, inteiro, acabado, como não acontece quando feito por mãos humanas; um novo pensamento e um novo amor, até dá medo... E não há nada superior no mundo!” (DOSTOIÉVSKI, 2004, p. 574). É nesse contexto de felicidade suprema que sai de casa para romper definitivamente com o grupo, momento em que ocorre o assassinato.

Destaca-se que o método de assassinato de Chátov é concebido por Stavróguin: "Convença quatro membros do círculo a matarem um quinto sob o pretexto de que ele venha a denunciá-los, e no mesmo instante você prenderá todos com o sangue derramado como se fosse um nó. Eles se tornarão seus escravos, não se atreverão a rebelar-se" (DOSTOIÉVSKI, 2004, p. 375). Na prática, os assassinos foram cinco, entre eles Vierkhoviénski. O conselho aponta para a morte como um acontencimento que, na arena de Stavróguin, se dá em cadeia. O marido da parteira que trabalhou no parto da criança tenta dissuadir os companheiros de que não é preciso ir adiante com o empreendimento, pois Chátov havia ficado feliz com o nascimento da criança e o retorno da ex-mulher, portanto, não mais os delataria. Vierkhoviénski afirma que não há "felicidade no fato de ter a mulher dele aparecido três anos depois para dar à luz de um filho de Stavróguin" (DOSTOIÉVSKI, 2004, p. 582). A observação de Virguínski destaca o quanto há de cruel na relação entre Chátov e Stavróguin, pois é sempre esperança desperdiçada. O fidalgo dá a ele motivos concretos para começar uma nova vida, seja por meio do nascimento da criança, seja pelo compartilhamento de uma ideia positiva, porém, tratam-se de sementes bastardas e contaminadas. Há frustração também pelo fato de Stavróguin não ter agido à altura das expectativas criadas pelo jovem.

Chátov é jogado ao chão e imobilizado pelos radicais, mas a morte ocorre sob o gatilho de Vierkhoviénski, à queima-roupa. $\mathrm{O}$ rapaz falece quase imediatamente. ,0O assassino principal vasculha os bolsos do cadáver, mas não encontra dinheiro, apenas "um bilhete de um escritório, o título de um livro e uma velha conta de uma taverna do estrangeiro, que sabe Deus por que motivo conservara durante dois anos no bolso" (DOSTOIÉVSKI, 2004, p. 586). Amarram pedras no corpo e pretendem afogá-lo imediatamente em um tanque, mas não é o que ocorre. Ao ver o defunto, Virguíski grita que não era para aquilo ter acontecido. Liánchim o segura por trás, como que para calar o companheiro, mas em vez disso, ele mesmo começou a gritar "feito um possesso":

Liámchin começou a gritar com uma voz que não era de gente, mas de algum animal. Apertando Virguínski por trás cada vez com mais e mais força e com um ímpeto convulsivo, gania sem cessar, sem intervalo, com os olhos arregalados para todos e a boca escancarada, enquanto sapateava miúdo no 
chão, como se ali reproduzisse o rufar de tambores. Virguínski ficou tão assustado que também gritou feito louco e, tomado de uma fúria e de um ódio que jamais se podiam esperar dele, começou a contorcer-se nas mãos de Liámchin, arranhando-o e batendo-lhe por trás com as mãos até onde conseguia atingi-lo. Finalmente Erkel o ajudou a afastar Liámchin (DOSTOIÉVSKI, 2004, p. 587).

O horror acabou quando tampam a boca de Liámchin com um lenço e jogam o morto na água. A descrição da cena é importante, pois mais uma vez a voz é recurso para afirmação da consciência e da individualidade. O componente de deformação gerado pela aquiescência ao conselho de Stavróguin atinge o código do discurso proferido: apesar de não conter qualquer palavra, a mensagem de remorso está clara. Chátov representa o abandono de ideias transgressoras em nome da salvação espiritual e por isso o atentado contra ele é mais grave que os outros crimes do romance (com exceção da violação de Matriósha, que segue o mesmo princípio: a exterminação de uma fonte de bondade e pureza do mundo).

Ainda sobre a influência de Stavróguin, ao incutir fé em Chátov, o fidalgo o conduz a um caminho mais positivo que aquele adotado por Kiríllov, mas era difícil que o ex-servo se salvasse, pois bebeu de fonte contaminada. Segundo Pareyson (2012, p. 38), "Chátov vive uma ideia degenerescente e negativa: o nacionalismo religioso, no qual a religiosidade é de tal modo atenuada que a crença em Deus é dispensada e diferida" (PAREYSON, 2012, p. 38). Chátov acredita que o povo russo é porta-voz de Deus, mesmo apesar de sua crença religiosa ser frágil e não estar totalmente consolidada, como implica o nome dele (Chátov lembra shatky, шаткий, que significa vacilante). Shneidman cita Carr (1984, p. 69) para defender que, por ter substituído o niilismo pela fé, era o único que poderia ajudar Stavróguin a sobreviver. Até mesmo a bofetada recebida poderia ajudar na redenção, possibilidade que é ignorada.

$\mathrm{Na}$ escala da autodestruição, Chátov representa a sede de fé e a possibilidade (perdida) de redenção. Em Os irmãos Karamázov, o stárietz Zóssima declara: “O que é o inferno? É o sofrimento de não mais se poder amar” (DOSTOIÉVSKI, 2008, p. 437). Chátov esteve bem perto de escapar da avalanche em direção ao abismo causada pela influência perniciosa de Stavróguin por meio da comunhão com a esposa e ao filho, mas o assassinato interrompe o seu processo de ressurreição. $\mathrm{O}$ nascimento da criança é um dos dois momentos em que o sentimento aparece no romance. Apesar do número reduzido de incidência, tem força potente, capaz de iluminar as trevas dos destinos de alguns personagens, imersos em tragédias. Stiepan Trofímovitch, a personagem que vive uma espécie de conversão diante da morte, ressalta a sua importância: "O amor 
está acima do ser, o amor é a coroação do ser, e como é possível que o ser não lhe seja reverente? Se eu me tomei de amor por Ele e me alegrei com meu amor, seria possível que ele apagasse a mim e a minha alegria e nos transformasse em nada?" (DOSTOIÉVSKI, 2004, p. 641).

A fala do professor sugere uma localização metaforicamente geográfica para o amor, sugerindo que ele possibilitava, portanto, uma ascensão, uma mirada para os céus. Para ter acesso a ele, era preciso ter humildade, reverência e abandono de si. Stavróguin era incapaz de qualquer um desses posicionamentos, portanto, a descrença apontada pelo diálogo com Chátov, somada ao vazio de seu coração, fazem a personagem ultrapassar o flerte com o abismo a adentrá-lo definitivamente.

\subsection{Piotr Vierkhoviénski e a semente da destruição}

Vierkhoviénski é o agitador da arena de Stavróguin. Por onde passa, causa discórdia e propaga o mal com fins revolucionários. A forma mais frequente de influência escolhida por ele é a mentira, a intromissão na vida alheia disfarçada de liberdade jovial, a manipulação por meio da lisonja. A ideia de destruição defendida por ele é: "Propõe-se que cerremos fileiras e formemos grupos com o único objetivo de provocar a destruição geral, pretextando que é impossível curar o mundo todo por mais que tratemos dele" (DOSTOIÉVSKI, 2004, p. 395).

Segundo Luiz Felipe Pondé, no estudo Crítica e profecia: A filosofia da religião em Dostoiévski, a personagem é "o indivíduo produtor das revoluções, e para Dostoiévski revolução só pode acabar mal, porque o ser humano não tem capacidade de construir um mundo para ele mesmo" (PONDÉ, 2003, p. 205). Ou seja, qualquer projeto baseado na razão humana que se afaste de Deus está fadado ao fracasso. Vierkhoviénski nega o divino não apenas ao defender a destruição de valores éticos, mas por meio do assassinato de Chátov, sob pretexto de que ele denunciaria a sociedade secreta. Quando descobre a disposição de Kiríllov de se matar, trata de arranjar que o suicídio do outro seja proveitoso para a causa revolucionária, fazendo com que ele assuma atos de destruição realizados na província. Destaca-se que há sempre algo de performance na criação de mártires: a decisão é sempre um ato político. ${ }^{33}$

Se Stavróguin influencia pessoas de forma quase displicente, Vierkhoviénski o faz de forma intencional e deliberada. O fato do radical ser o agente da discórdia vai ao

\footnotetext{
${ }^{33}$ Observação apontada pelo professor Augusto Rodrigues da Silva Jr.
} 
encontro ao que Lukács discorreu sobre Dostoiévski. Segundo o teórico (1968, p. 167), Dostoiévski soube retratar muito bem a miséria da metrópole. Petersburgo ainda não era uma cidade digna desse nome, porém, era o mais próximo disso encontrado na Rússia da época e Dostoiévski soube captar que a cidade era berço das mudanças "sociais, morais e psicológicas" que se aproximavam. "Nas tragédias desenvolvidas nas pequenas cidades, os personagens decisivos são aqueles que como Stavróguin e Ivan vivem em Petersburgo, assim, o que vem de baixo, a miséria, continua sendo a essência de toda a sociedade" (LUKÁCS, 1968, p. 167). Vierkhoviénski (bem como Stavróguin) não só "veio" da capital, como começou a atividade revolucionária por lá.

Quando fala com Vierkhoviénski, Stavróguin adota tom impaciente, mas condescendente e por vezes se deixa divertir, mesmo que pouco, por ele. Admira o entusiasmo e decisão no outro, atributos que lhe faltam. Relação semelhante se dá em Os irmãos Karamázov. Ivan tem simpatia por Smierdiákov, mas depois passa a detestálo, principalmente quando o outro começa a se portar com mais liberdade diante dele. "Smierdiákov passou visivelmente a se considerar, sabe Deus por quê, como que solidário com Ivan Fiódorovitch, falava sempre em tom que dava a impressão de que entre os dois já havia algo combinado e como que secreto" (DOSTOIÉVSKI, 2008, p. 370). O Karamázov sempre pretendia agir com rispidez diante do outro, mas quando finalmente conversam, o tom é mais pacífico. A inimizade exacerbada se dá como mecanismo do jovem para lidar com a própria consciência, já que o jovem sabe que o irmão bastardo trama contra a vida do pai e não faz nada para impedir, pelo contrário, até o ajuda, informando ao outro que não estaria na cidade no dia em que o ato estava planejado para ocorrer. Da mesma forma, Stavróguin não gosta especialmente de Vierkhoviénski, mas o tolera e incentiva seus planos violentos de forma velada.

Assim como em Chátov, o componente de adoração no que diz respeito a Stavróguin está presente em Vierkhoviénski, mas com aspecto político. "Você me apresentou lá como algum tipo de chefe? - deixou escapar Nikolai Vsievolódovitch com a maior displicência possível. Piotr Stiepánovitch olhou rápido para ele" (DOSTOIÉVSKI, 2004, p. 225). O aparente desinteresse do fidalgo, a ausência de resposta direta e a olhadela do radical revelam como o calar da voz pode significar cumplicidade. O plano do jovem revolucionário é lançar Stavróguin como figura substituta do czar quando a destruição completa se realizar:

Ouça, não vou mostrá-lo a ninguém, a ninguém: assim é preciso. Ele existe, mas nunca ninguém o viu, está escondido. Sabe, poderia mostrá-lo a um só em 
cem mil, por exemplo. E por toda a terra se espalharia: "Vimos, vimos". [...] você é belo, orgulhoso como um deus, não procura nada para si, tem a auréola do sacrifício, "está escondido". O principal é a lenda! Você os vencerá, lançará um olhar, vencerá (DOSTOIÉVSKI, 2004, p. 411).

Segundo Vierkhoviénski, Stavróguin é parte fundamental do seu plano. Diz que sem ele, é "uma mosca, uma ideia dentro de uma garrafa, um Colombo sem América" (DOSTOIÉVSKI, 2004, p. 409). Tal conversa encontra-se no capítulo VIII da segunda parte ("Ivan Czariêvitch"). Piotr Vierkhoviénski representa a negação completa da deidade, o niilista sem possibilidade de salvação em um mundo esvaziado de sentidos, cuja missão é destruir os poucos restantes. Fiédka, um fugitivo da prisão que realiza tarefas clandestinas para ele, o descreve nos seguintes termos: "Já não acredita nem um pouquinho no criador celestial, que nos fez de barro, e diz que foi a natureza que fez tudo, teria feito até o último animal" (DOSTOIÉVSKI, 2004, p. 279). Ao cobrar um artigo que o pai precisava escrever, recomendou que o texto não possuísse absurdos e que contivesse "fatos, fatos e fatos", uma contraposição às "palavras, palavras, palavras" shakespearianas, destacando que ele era um homem de ação, um homem cuja existência baseava-se nas verdades científicas e observáveis. O fato de ser ateu não o impediu, porém, de eleger Stavróguin como seu novo Deus, assim como Dostoiévski acreditava que o positivismo fazia em relação à ciência.

Sobre a negação de Cristo por meio de revolução, Coates (2001) afirma que Dostoiévski via semelhanças entre o catolicismo e o socialismo ateu, por causa do conceito de paraíso terrestre propagado por eles. No mesmo sentido, Chátov lembrou a Stavróguin que ele havia criticado duramente a Igreja Católica. "[...] No entanto você foi mais longe ainda: acreditava que o Catolicismo romano já não era Cristianismo; afirmava que Roma proclamou um Cristo que se deixou seduzir pela terceira tentação do demônio" (DOSTOIÉVSKI, 2004, p. 249). Em Os irmãos Karamázov, o tema está presente. Segundo o Grande Inquisidor, Cristo havia errado ao resistir às tentações do demônio. Ao evitar comprovar sua divindade por meio do milagre com vistas a manter o livre-arbítrio do homem, havia desconsiderado o fato de que a raça humana não sabe lidar com a liberdade. "Eu te digo que o homem não tem uma preocupação mais angustiante do que encontrar a quem entregar depressa aquela dádiva da liberdade com que esse infeliz nasce" (DOSTOIÉVSKI, 2008, p. 353). À primeira oportunidade, segundo ele, os humanos não hesitam em trocar o pão dos céus pelo pão da terra, o amor verdadeiro pela adoração aos falsos ídolos. A Igreja Católica exercia papel nobre ao dominar os homens em nome de Deus, pois os tiraria de seu sofrimento existencial. 
"Existem três forças, as únicas forças na terra capazes de vencer e cativar para sempre a consciência desses rebeldes fracos para sua felicidade: essas forças são o milagre, o mistério e a autoridade" (DOSTOIÉVSKI, 2008, p. 354). Piotr Vierkhoviénski parece concordar com esse princípio ao conceber o plano de lançar Stavroguin como o chefe de sua revolução absurda. Percebe que o povo russo estava perdido e sem foco e que se deixaria dominar facilmente por uma falsa promessa de verdade. Tal utopia seria impossível pois estava fora da fé e só poderia ser instaurada por meios violentos e a custo da liberdade individual, valor que o escritor julgava imprescindível.

Stavróguin influenciou Vierkhoviénski de forma displicente, aparentemente descompromissada, mas foi por meio dessa dúbia relação que o caos generalizado e várias mortes se concretizaram. Vierkhoviénski representa o Anticristo, aquele que propagava o fim dos tempos, a negação que é puro mal e vazio. Representa um estágio seguinte da decomposição da arena de Stavróguin: o amoralismo completo que vende falsos deuses, mas esses ainda são externos. A presença do niilista no romance significa uma avalanche desenfreada de caos, desmoronamento no qual houve força inicial com intenções destrutivas: arrastar e destruir tudo pelo caminho. Trata-se de um nível intermediário de descida no inferno pessoal de Stavróguin, pois ainda não está presente a heresia suprema de autousurpação do trono supremo, traço encontrado em Kiríllov.

\subsection{Kiríllov e a ideologia do suicídio}

Em Kiríllov, a noção metafórica de inferno dos vivos está plenamente consolidada. Houve influência maligna por meio de Stavróguin, bem como assimilação criativa do pupilo. Em todo o enredo desse personagem, paira a imagem do anjo que quer tomar o lugar de Deus e por isso decai, ou seja, e por isso se torna demônio. Outra metáfora que também não pode ser desconsiderada é a do homem que busca conhecer toda a verdade sobre o bem e o mal, com vistas a acessar o conhecimento de Deus sobre o universo e, por causa da ousadia, perder o acesso e possibilidade de habitar o paraíso. Matou-se para ocupar o trono de Deus e para afirmar o seu livre-arbítrio.

Antes de se suicidar, Kiríllov se ocupou com a escrita de um artigo sobre "as causas dos casos de suicídio que se tornaram frequentes na Rússia e em geral sobre as causas que aceleram ou inibem a difusão do suicídio na sociedade" (DOSTOIÉVSKI, 2004, p. 100). O texto demonstra uma tendência, apresentada pelos personagens do romance, de externalizar questões existenciais para tentar compreendê-las, seja por 
diálogo ou por escrito. Pouco é discutido sobre o documento e o romance não transcreve trechos contidos nele. $\mathrm{O}$ texto é importante por causa da forma que a personagem reage à sua menção. Quando Liputin toca no tema do suicídio, Kiríllov diz que não está escrevendo artigo nenhum e que o outro não tem direito de falar sobre o assunto. Nega o próprio escrito e fica extremamente irritado, como se Liputin estivesse invadindo a sua liberdade de forma violenta. Kiríllov afirma que havia conversado com o outro sobre o tema apenas por curiosidade e que não tem pretensões editoriais/literárias.

A técnica de colocar um personagem para escrever sobre os temas de força dos romances dos quais fazem parte já havia sido utilizada por Dostoiévski. Como mencionado anteriormente, Ivan estilizou dúvidas religiosas no poema sobre o Grande Inquisidor. Em Crime e castigo, antes de assassinar a velha usurária, Raskólnikov desenvolve um artigo sobre seres humanos superiores que teriam liberdade para matar em nome de seus objetivos, numa verdadeira escrita de morte. Mata para descobrir se faz parte do seleto grupo, mas se descobre um "piolho" em vez de um "Napoleão". Do mesmo modo, o artigo de Kiríllov contrapõe o seu presente e futuro. Ao padecimento físico, precedeu a sua morte simbólica e o "desligamento" dos assuntos vitais. Havia concordado em usar o próprio suicídio em prol da atividade revolucionária, com a qual não simpatiza, o que indica que não está mais preocupado com a narrativa pessoal biográfica que deixará após a morte: "Eu disse que esperaria até que me dissessem o prazo dado pela Sociedade, porque para mim é indiferente" (DOSTOIÉVSKI, 2004, p. 364). Escrever sobre o suicídio, portanto, é a única atividade possível para um homem que já havia se despedido da vida interiormente, que não mais se sente ligado aos assuntos terrenos e que espera apenas um sinal de Vierkhoviénski para se despedir materialmente do mundo. Vale lembrar que discursar sobre a morte antes da despedida definitiva foi ação realizada por Sócrates.

Segundo a própria personagem, ele havia passado quatro anos sem travar relações sociais (revelando-se um verdadeiro homem do subsolo) e apenas conversava com pessoas relacionadas ao seu objetivo de vida (não diz qual é, mas trata-se do suicídio metafísico). Afirma que nunca falava nada para ninguém e que não discutia “questões que estão inteiramente encerradas" (DOSTOIÉVSKI, 2004, p. 101), dando a entender que não precisava mais falar sobre o suicídio. Segundo Camus (2010, p. 50): “Para um espírito absurdo, a razão é vã e não existe nada além do absurdo". Tudo indica, portanto, que já estava decidido em relação a tirar a própria vida ao aparecer na cidade e que os quatro anos anteriores haviam sido fundamentais para $o$ 
desenvolvimento da "ideia". Não por acaso, nessa conversa é revelado que ele havia conhecido Stavróguin no tempo que estivera no exterior, já sinalizando que haviam travado relações e que elas haviam sido decisivas para que ele tomasse a decisão.

Em diálogo com Stiepan Trofímovitch, ouve que não vão deixá-lo construir ferrovias e pontes se ele acreditar no princípio da destruição universal. Destaca-se que ambos os elementos possuem função de "ligação": as ferrovias ligam pontos geográficos, a destruição universal seria um estágio para uma mudança estrutural da sociedade. Ao ouvir isso, Kiríllov ri, demonstrando que não está preocupado nem com a construção de pontes, nem com a destruição universal, pois sabe que em breve estará morto e nenhuma daquelas questões lhe diz respeito. Sobre esse aspecto do homem que não se identifica mais com questões terrenas, Camus (2010, p. 70) explica: “O homem absurdo, totalmente voltado para a morte (tomada aqui como a absurdidade mais evidente), sente-se desligado de tudo que não é a atenção apaixonada que se cristaliza nele. Saboreia uma liberdade em relação às regras comuns". Em um diálogo bastante emblemático o protagonista revela que já havia pensado na possibilidade de se matar:

\footnotetext{
- É claro que compreendo o suicídio - retomou Nikolai Vsievolódovitch um tanto carrancudo depois de um longo e pensativo silêncio de três minutos -, vez por outra eu mesmo tenho imaginado isso, mas aí sempre me vem um pensamento novo: se for para cometer algum crime ou, o principal, uma desonra, ou seja, uma ignomínia, que seja muito infame e... engraçada, de sorte que as pessoas venham a lembrar-se dela por mil anos e por mil anos repudiá-la; e de chofre me vem uma ideia: "Um golpe nas têmporas e não restará nada". Que importam as pessoas e que elas passem mil anos repudiando, não é? (DOSTOIÉVSKI, 2004, pp. 236-237).
}

Acrescente-se a isto uma forma sinestésica de encarar os pensamentos: "Quando uma vez pensei nisso, senti-o como uma ideia completamente nova" (DOSTOIÉVSKI, 2004, p. 237). Stavróguin compara a noção de desvencilhamento dos erros de uma vida anterior a uma temporada na lua. Enquanto a pessoa lá vivesse e enquanto existisse lua, as pessoas se lembrariam dos acontecimentos. Porém, quando essa pessoa se afastasse da lua, o passado não mais importaria. Mais uma vez o suicídio é apontado como libertação no que diz respeito às narrativas pessoais construídas durante a vida. Os personagens suicidas querem se livrar da responsabilidade de deixar um legado biográfico positivo à posteridade. No caso de Kiríllov, porque tem objetivos que ultrapassam a condição humana; no caso de Stavróguin, porque considera seus atos vergonhosos e merecedores de serem esquecidos.

A questão da liberdade humana também é panorama da estilização de seu destino. Segundo Camus (2010, p. 68): “O problema da 'liberdade em si' não tem 
sentido. Porque está ligado de uma outra maneira ao problema de Deus. Saber se o homem é livre exige saber se ele pode ter um amo". Para Kiríllov, a questão do livrearbítrio (bem como a questão da existência do bem e do mal) está essencialmente ligada ao fato de o trono de Deus estar vazio e à possibilidade de ocupá-lo. O pensamento de Kiríllov explica não só a felicidade, mas também a maldade: "Eles são maus porque não sabem que são bons. Quando souberem não irão violentar uma menina. Precisam saber que são bons, e no mesmo instante todos se tornarão bons, todos, sem exceção. Aquele que ensinar que todos são bons concluirá o mundo" (DOSTOIÉVSKI, 2004, p. 239). Kiríllov afirma que o responsável por esta realização será o Homem-Deus, e não Cristo crucificado, que foi o Deus-Homem, e que há grande significado nessa inversão.

A personagem tinha plena consciência de ter sido influenciada por Stavróguin, principalmente no que dizia respeito à questão de Deus. Ao saber que o jovem supostamente ateu costumava rezar, o fidalgo diz: "Aposto que quando eu voltar aqui você já estará acreditando em Deus. [...] Se você já soubesse que acredita em Deus você acreditaria; mas como você ainda não sabe que acredita em Deus então não acredita deu um risinho Nikolai Stavróguin”. Kiríllov censura o outro pela galhofa e afirma: “Lembre-se do que representou em minha vida, Stavróguin" (DOSTOIÉVSKI, 2004, p. 240). O rapaz é exemplo da visada bakhtiniana sobre a tanatografia em Dostoiévski: o fato de a morte nunca ser vivenciada internamente. Afirma amar a vida e não enxerga no fato uma contradição com a decisão de se suicidar: "A vida é um particular, a morte também é um particular. A vida existe, mas a morte não existe particularmente" (DOSTOIÉVSKI, 2004, p. 237).

Ainda sobre a relação de Kiríllov com Stavróguin, olhar o protagonista como metáfora da Rússia do século XIX ajuda a compreender não só essa influência, mas a que ele exerceu em Chátov. Cada um dos pupilos representa uma resposta diferente aos conflitos filosóficos e religiosos do fidalgo, assim como os eslavófilos e os ocidentalistas forneciam possibilidades teóricas o país, à época. Joseph Frank (2003) destaca que, assim como os personagens mantiveram contatos amigáveis no passado e romperam por discordâncias conceituais, o mesmo ocorreu com os dois movimentos culturais russos: “As crenças tanto de Kiríllov quanto de Chátov são apresentadas como substitutos seculares da fé religiosa genuína e espontânea que ambos, a exemplo de seu mentor, desejam, mas não conseguem atingir” (FRANK, 2003, p. 611).

Para Paperno (1997, 141), o "antropoteísmo" de Kiríllov, que dialoga com Feuerbach, corresponde ao "você será deus" da serpente. O sopro da morte, portanto, só 
poderia ter vindo de Stravóguin, o que de fato ocorreu. Para Paperno (1997), o modelo da trajetória de Kiríllov é platônica, com referências a Fédon, ou seja, feita por diálogos sobre a morte e a imortalidade que culminam em suicídio. A morte da personagem, inclusive, seria uma atualização das mortes de Sócrates e Cristo. Paperno (1997, p. 145) explica que Kiríllov se perde no meio de um silogismo que envolve a necessidade moral da existência de Deus e o conhecimento empírico de sua ausência. Não compreendeu que a fé em Deus está além da compreensão racional. Paperno (1997, p. 146) apresenta alguns paralelos entre Cristo e Kiríllov. O trabalho na construção de uma ponte é metáfora para o fato de ele ser um mediador entre a condição humana e divina, entre o céu e a terra. Assim como Cristo, Kiríllov tenta salvar a humanidade por meio de um tipo de morte autoinflingida. Dessa forma, Dostoiévski se inseriu na discussão teológica que questiona se a morte na cruz pode ou não ser considerada suicida. A estudiosa explica que, se na oração de Getsêmani, Cristo afirma que "seja feita a vossa vontade", Kiríllov afirma, simbolicamente, "seja feita a minha vontade" por meio de um suicídio claro. Um Cristo empoderado, dotado de livre-arbítrio, assumidamente suicida é o novo deus. O suicídio perpetrado por um ateísta apresenta aqui uma variável deturpada de imitatio Christi. Ainda sobre a questão da morte de Kiríllov, Sciacca responde: "Cristo e Kiríllov: o martírio por fidelidade absoluta à fé na Verdade absoluta; o suicídio por desespero absoluto de que Deus seja mentira, mas para provar que isso é assim" (SCIACCA, 2012, p. 254). Vale destacar que Chátov acreditava em Deus apenas racionalmente. Kiríllov era ateu, mas acreditava fervorosamente, por sentimento.

György Lukács (1968, p. 172) discorreu de forma genérica sobre alguns personagens dostoievskianos, mas fornece uma boa descrição para Kiríllov: "Exatamente os seus personagens ateus apresentam a mais verdadeira profundidade de ideias, o mais verdadeiro fervor de pesquisa". Na mesma linha, Thomas Mann fornece uma reflexão sobre a poética dostoievskiana que serve muito bem para Kiríllov, ao discorrer sobre a “[...] grandeza religiosa dos amaldiçoados, do gênio como doença e da doença como gênio, do tipo atormentado e do possesso, no qual o santo e o criminoso se tornam um só..." (MANN, 2011, p. 114).

Segundo Frank (2003), Kiríllov é o lado demoníaco de Stavróguin dotado de moral elevada. Kiríllov trata a transcendência como se ela fosse uma espécie de trono abandonado pelo ocupante anterior e estivesse à espera do sucessor. Suicida-se na intenção de virar o homem-Deus, a nova Divindade. "O raciocínio é de uma clareza clássica. Se Deus não existe, Kiríllov é Deus. Se Deus não existe, Kiríllov deve se 
matar. Kiríllov deve se matar, então, para ser deus. Esta lógica é absurda, mas é o que se necessita" (CAMUS, 2010, p. 121). Sobre Deus e o suicídio de Kiríllov, Maurice Blanchot escreve, em $O$ espaço literário: “Os homens, pensa ele, se não se matam é porque têm medo da morte; o medo da morte é a origem de Deus; se posso morrer contra esse medo, terei libertado a morte do medo e derrubado Deus. [...] Deus é, para ele, o rosto de sua morte" (BLANCHOT, 2011, p. 102) ${ }^{34}$.

O suicídio de Kiríllov é descrito imediatamente após a morte de Chátov. Na ocasião, reafirma que tudo lhe era indiferente. Vierkhoviénski pede que o outro comece a escrever o bilhete suicida. "O senhor vai escrever que brigou com ele por causa da traição e da delação... hoje à noite... e foi essa a causa da sua morte" (DOSTOIÉVSKI, 2004, p. 593). O engenheiro fica estarrecido ao saber da morte do jovem e pega o revólver, ameaça matar o outro e diz que não escreverá mais nada, o que demonstra que ele ainda era capaz de se sensibilizar com os homens (o que já tinha ficado claro quando ele se esforçou para divertir uma criança).

Kiríllov representa um estágio profundo na escala que leva Stavróguin ao aniquilamento. Trata-se também do estágio final da condição humana já que, por meio do suicídio e da negação racional da divindade, a personagem busca colocar-se em oposição à Deus e usurpar o seu trono. Sobre estas indagações, Camus (2010, p. 41) discorre: "O espírito que chega aos confins deve emitir um juízo e determinar suas conclusões. Aí se localizam o suicídio e a resposta". Destaca-se que até mesmo antes da morte, Kiríllov continua a discursar e buscar sentido para sua existência absurda: "Deus é necessário, por isso deve existir. [...] Mas eu sei que ele não existe e nem pode existir. [...] Porventura não compreendes que um homem com dois pensamentos como esses não pode continuar entre os vivos?" (DOSTOIÉVSKI, 2004, p. 596). Kiríllov afirma ainda que se Deus não existia, toda vontade lhe pertence, portanto, ele mesmo é Deus. "O homem não tem feito outra coisa senão inventar um deus para viver, sem se matar; nisso tem consistido toda a história do mundo até hoje. Sou o único na história do mundo que pela primeira vez não quis inventar um deus" (DOSTOIÉVSKI, 2004, p. 598). Sobre a existência de Deus e livre-arbítrio, Camus (2010, p. 68) problematizou: "Diante de Deus, mais que um problema da liberdade, há um problema do mal. A

\footnotetext{
34 A ausência de Maurice Blanchot no trabalho deve-se à incompatibilidade com certos pressupostos bakhtianos, abordagem adotada na presente análise. Porém, a questão da morte é importante para o estudioso francês e aponta para uma profunda reflexão sobre o tema, na vida e na literatura.
} 
alternativa é conhecida: ou não somos livres e o responsável pelo mal é Deus todo poderoso, ou somos livres e responsáveis, mas Deus não é todo poderoso".

Destaca-se que é falar sobre sua liberdade que o faz decidir por assinar o bilhete, ditado por Vierkhoviénski, no qual assume a responsabilidade pela morte de Chátov:

\begin{abstract}
"Eu, Aleksiêi Kiríllov - ditava em tom firme e imperioso Piotr Stiepanovitch, inclinado sobre o ombro de Kiríllov e observando cada letra que o outro escrevia com a mão trêmula de emoção. - Eu, Kiríllov, declaro que hoje, ...de outubro, à noite, às oito horas, matei o estudante Chátov, por traição, no parque, por ter delatado os panfletos, e Fiedka, que esteve hospedado secretamente e pernoitou durante dez dias em casa de nós dois no prédio de Fillípov. Eu mesmo me mato hoje com um revólver, não porque esteja arrependido e tema os senhores, mas porque já no estrangeiro tinha a intenção de interromper a minha vida" (DOSTOIÉVSKI, 2004, p. 602).
\end{abstract}

Depois de redigir o bilhete, pega o revólver e fecha-se no quarto. Quando Vierkhoviénski entra, o jovem joga-se contra ele e grita "com fúria animal". O niilista sai do cômodo sem saber se Kiríllov ainda se matará. Quando abriu a porta novamente, tem acesso à uma visão pavorosa.

[...] em um canto formado pela parede e o armário, Kiríllov estava em pé, numa posição, numa posição estranhíssima: imóvel, esticado, em posição de sentido, com a cabeça soerguida e a nuca colada na parede, bem no canto, parecendo que queria esconder-se e sumir por completo. Súbito [Vierkhoviénski] foi tomado de um furor total: despregou-se do lugar, começou a gritar e, batendo com os pés, lançou-se furiosamente para o terrível canto (DOSTOIÉVSKI, 2004, p. 604).

Apesar da abordagem, Kiríllov não move um músculo, o rosto está sobrenaturalmente pálido e os olhos, fixos em uma direção qualquer. Vierkhoviénski o agarra pelo ombro. "Lembrou-se apenas de que, fora de si, batera três vezes com toda a força com o revólver na cabeça de Kiríllov, que caíra sobre ele e lhe mordera o dedo" (DOSTOIÉVSKI, 2004, p. 604). Saiu correndo desesperadamente do local, quando ouve um disparo. Retorna ao cômodo e com a ajuda de um palito de fósforo, enxergam o cadáver. A bala havia atravessado a sua têmpora esquerda, perfurando-lhe o crânio: "Viam-se salpicos de sangue e cérebro. O revólver permanecera na mão do suicida arriada no chão. A morte devia ter sido instantânea” (DOSTOIÉVSKI, 2004, p. 605).

Para Paperno (1997), o suicídio de Kiríllov é um novo paradigma de morte, um que combina com a era do ateísmo e do positivismo. Ela explica que o narrador não descreve sobre o momento exato da morte: a arma dispara atrás das cenas. A vivissecção artística não captura o momento em que a morte ocorre. A experiência do morrer permanece inacessível até mesmo para o artista. Dostoiévski promove um apagamento por meio do narrador, que acrescenta dialogismo à escrita da morte: na 
medida em que não se oferece uma imagem do ato do morrer, ele se torna muito mais potente. O leitor se torna outra voz na composição da cena, à medida que é convocado a participar dela com leitura criativa e imaginativa.

O autoaniquilamento de Kiríllov, que sai do caos dos vivos e se lança ao abismo dos suicidas, reforça o aspecto de decadente da influência de Stavróguin. Apesar de elevado nos ideiais e de profundo na inteligência, a morte da personagem é bastante indigna, na medida em que ele aceita assumir um crime que não cometeu. Ao revelar a disposição de assumir o trono de Deus, o intelectual assumiu a faceta de anjo caído, de criatura que se contrapôs à Deus com mergulho na blasfêmia. Representa um nível bastante profundo do processo de autodestruição de Stavróguin, pois a morte dele corta um dos últimos laços do fidalgo com o mundo material. A morte do protagonista se deu após a de Kiríllov e não poderia ser de outra forma, pois ao perder outra parte discursiva de si, ou seja, não restou a Stavróguin mais que a lembrança das verdades outrora professadas. Todo o vazio de seu ser foi explicitado. Como discutiu a questão da morte do ex-pupilo, é possível acreditar que a decisão do outro o ajudou a criar a coragem para realizar o ato definitivo. Ao convencer o outro sobre as vantagens de tirar a própria vida, a sábia serpente matou qualquer vestígio de esperança que talvez ainda subsistisse em seu ser. O inferno dos vivos dostoievskiano é um corpo diante da morte que não consegue crer em um paraíso para a alma.

\subsection{Três mortes ${ }^{35}$}

Tanto as mortes de Chátov quanto a de Kiríllov apresentam elementos de animalidade e selvageria. Segundo Paperno (1997, p. 158), Kiríllov morre não como um Homem-deus, mas como louco, animal que urra, berra, chuta, morde. Pareyson (2012, p. 35) afirma que, na morte, em vez de super-homem, Kiríllov se torna "sub-homem". Vale notar que Chátov é praticamente abatido como um bezerro, "sacrificado" em nome da causa e dos propósitos perversos de Vierkhoviénski.

Joseph Frank (2003) explica que a manifestação ensandecida dos radicais após o assassinato de Chátov ocorre porque eles, apesar de matarem, não menosprezam o valor da vida humana. Eles também não acreditavam completamente que Chátov os delataria. A atitude apresentada por Kiríllov, porém, dá-se porque, em vez de uma morte altiva,

${ }^{35}$ Referência à análise da representação das mortes em Tolstói e Dostoiévski, realizada por Mikhail Bakhtin em Problemas da poética de Dostoiévski. 
ele manifesta um pânico profundo. Segundo Frank (2003, p. 641), o aniquilamento de Deus, "longe de causar um domínio sobre a dor e o medo da morte, ocasiona o frenesi animal com que Kiríllov mete os dentes nas mãos de Piotr Vierkhoviénski. [...] O suicídio de Kiríllov é a autonegação e auto-refutação de suas próprias ideias grandiosas" (DOSTOIÉVSKI, 2004, p. 641). Ao falar do medo da morte, Philippe Ariès (2013, p. 37) o caracteriza como um aspecto inerente à modernidade. Segundo o pesquisador, "a atitude antiga que vê a morte ao mesmo tempo próxima, familiar e diminuída, insensibilizada, opõe-se demais à nossa, onde nos causa tanto medo que nem ousamos dizer-lhe o nome". Para o estudioso, a morte da modernidade é "selvagem", enquanto a morte dos antigos era "domada".

Segundo Shneidman (1984, p. 61), a cena do suicídio de Kiríllov demonstra uma luta interior da personagem entre o desejo instintivo de viver e a decisão racional de morrer. Para o teórico (1984), apenas quando a vontade de viver é totalmente destruída pelo desejo de morrer uma pessoa pode se matar sem remorso ou luta interior. Shneidman afirma que a luta entre a decisão racional de se matar e o desejo irracional de viver pode ser observado nos últimos momentos de vida de Kiríllov. O estudioso também destaca que até o momento final, Vierkhoviénski não sabe se o outro vai realmente cometer suicídio ou se mudará de ideia e o matará. Cita a teoria segundo a qual a justificativa de Kiríllov de que se mataria para provar que era Deus não é verdadeira e que na verdade ele se mata por estar consciente de não ser Deus.

Enquanto os falecimentos de Kiríllov e Chátov evocam um clima de bestialidade, a do antigo professor apresenta características positivas. $\mathrm{O}$ homem supera a posição abstrata que sempre adotou em relação à vida e sai em peregrinação ao fim do romance, numa busca com fins religiosos. Ao procurar a Rússia, entra em contato com o povo. Segundo Frank (2003, p. 643), "nada é mais delicado, nesse livro tão cheio de páginas admiráveis, do que o contato assustado entre o 'liberal' protegido e mimado, que passou a vida inteira a proferir frases elegantes e observações depreciativas sobre o povo russo, e os camponeses espantados”. Segundo o teórico, há mútua compreensão entre os lados, apesar de terem vindo de panoramas sociais tão diferentes. Quando Stiepan Trofímovitch encontra a vendedora de evangelhos, a discussão religiosa tornase mais evidente. Vale destacar que Stiepan Trofímovitch não é exatamente um ateu, diz que acredita no ser supremo, mas só à medida em que Deus o utiliza como instrumento para tomar consciência de si mesmo. 
No leito de morte, quando recebe a visita e cuidados de Varvara Pietrovna, não demonstra medo da morte. O narrador explica que a despreocupação talvez se deva ao fato de não acreditar no diagnóstico do médico, segundo o qual tem pouco tempo de vida. Comunga e afirma que "Deus já me é necessário porque é o único ser que se pode amar eternamente" (DOSTOIÉVSKI, 2004, p. 640). Afirma também que, se Deus realmente existir, ele é imortal. "Minha imortalidade já é necessária porque Deus não vai querer cometer um engano e apagar inteiramente o fogo do amor que já se acendeu por Ele em meu coração" (DOSTOIÉVSKI, 2004, p. 640). Isto ainda é reforçado com uma imagem que abriga a metáfora-título do livro:

\begin{abstract}
Stiepan Trofímovitch não morre como cristão no sentido estrito da palavra, mas a leitura do Sermão da montanha instiga-o a reconhecer: "Minha amiga, durante toda a minha vida eu menti". E, após ouvir a passagem de Lucas sobre "Os demônios" que entraram na vara de porcos, declara: "Somos nós, nós e aqueles... e Petruchka e les autres avec lui... e eu talvez à frente deles". Essas palavras, embora coerentes com a estrutura da trama, dificilmente conferem importância bastante a Stavróguin (FRANK, 2003, p. 644).
\end{abstract}

Morre proclamando que todo homem deveria se inclinar diante da Grande Ideia e que é extremamente necessário viver acreditando em algo maior que a própria existência, o que não é um pensamento religioso, mas também não é uma afirmação meramente centrada no humano. Afirma que "se os homens forem privados do infinitamente grande não continuarão a viver e morrerão no desespero" (DOSTOIÉVSKI, 2004, p. 641). Falece suavemente, “como uma vela que acabou de queimar". Por meio dessa morte, destaca-se que o poder de influência é tanto mais forte quanto mais consciente. A potência do poder catequizador de Stavróguin em Chátov e Kiríllov só pôde ser tão profunda porque eles permitiram se convencer, porque um personagem foi ativo no processo de infernizar uns aos outros. Por ter sido o primeiro contato sentimental de Stavróguin, o responsável por incutir nele a personalidade melancólica e reflexiva, o homem liberal tem tudo para também acabar se autodestruindo ao fim do romance. É salvo por sua decisão, por ter escolhido aproximar de uma verdade transcendental. Fica demonstrado que o inferno é mais sombrio na medida em que o caminhante se decide por aquela que é a pior cegueira, a pior derrota: o daquele que não quer ver, o daquele que não se dispõe a lutar por si mesmo. 


\subsection{O esvaziamento da arena}

A arena de Stavróguin aos poucos se desmonta por causa da morte. Vierkhoviénski comete assassinato e foge da cidade. Chátov é morto. Kiríllov se suicida. Shneidman afirma que, enquanto existia o mundo das intrigas e os pequenos demônios que as propagavam, havia espaço para ele existir. Porém, quando o ambiente se desintegra e os adoradores de Stavróguin se ausentam, não há mais justificativa para a existência dele. Para Bakhtin (2010a), ensimesmar-se é sinônimo de perdição e no fim, ele acaba consumido pelo mesmo fogo que destruiu aqueles que o enxergavam como líder. Mata-se apenas quando os fracos elementos que o ligam à existência, os participantes da arena, desaparecem. Destaca-se que as três principais relações dialógicas mantidas por Stavróguin polemizam com ideias em circulação à epoca, mas devem ser pensadas, principalmente, do ponto de vista romanesco. Ou seja, os diálogos que mantém com Vierkhoviénski, Chátov e Kiríllov são estágios do percurso que o levam ao suicídio. Segundo Shneidman (1984, p. 64), Stavróguin, o "arquidemônio", irradia a ruína e acaba alienado. Dividiu-se tantas vezes que tornou-se um espectro.

Quanto mais ele expressa as próprias ideias por meio de terceiros, mais vazia e sem sentido a vida dele se torna. Retirados os pupilos de cena, Stavróguin mergulha definitivamente na solidão absurda e desesperançada: experiência que registra em escritos nos quais externaliza seus conflitos existenciais. Enquanto a arena está montada, há barulho, conversas, voz, som e fúria ${ }^{36}$. Quando ela se esvaziou, ficaram os documentos, meio utilizado por Stavróguin para tentar compreender a própria vida enquanto caminha em direção à morte. Em ambos os casos, as ideias dialogadas sobreviveram àqueles que os criaram, em verdadeiro exemplo de diálogos e escrita de morte. "Palavras, palavras, palavras"37, os golpes mais mortais da arena, cimento da construção capaz de sobreviver aos seus artesãos até o juízo final ${ }^{38}$ : a criação discursiva.

\footnotetext{
36 “Amanhã, e amanhã, e ainda amanhã/Arrastam nesse passo o dia-a-dia/Até o fim do tempo prénotado./E todo ontem conduziu os tolos/À via em pó da morte: Apaga, vela!/A vida é só uma sombra: um mau ator/Que grita e se debate pelo palco,/Depois é esquecido; é uma história/Que conta o idiota, toda som e fúria/Sem querer dizer nada.” Macbeth, Ato V, Cena V.

${ }^{37}$ Hamlet, Ato II, Cena II.

${ }^{38}$ Alusão ao diálogo dos coveiros em Hamlet.

Primeiro coveiro: "Quem é constrói mais solidamente do que o pedreiro, o construtor naval ou o carpinteiro?"

Segundo coveiro: "O que constrói a forca, pois essa estrutura sobrevive a mais de mil inquilinos."
} 


\title{
CAPÍTULO 5: LETRAS DA MORTE
}

\author{
De cada três pensamentos meus, \\ um será para minha sepultura.
}

William Shakespeare, A tempestade

\subsection{Personagens-autores}

O romance Os demônios é repleto de situações nas quais os personagens se colocaram em posição autoral ou editorial. O padre da cidade faz discursos de qualidade e as pessoas o incentivam a registrá-los em forma escrita e a publicá-los, o que demonstra que se valorizava esse tipo de expressão. Lebiádkin, apesar de toda a sua baixeza, escreve versos e se diz poeta e escritor de fábulas, ou seja, tem consciência de ser autor. Ao incentivar que o capitão registre e informe Liza sobre os seus sentimentos, Liputin diz a Lebiádkin: "Escreva, escreva, qualquer homem tem direito de correspondência" (DOSTOIÉVSKI, 2004, p. 266), elencando a comunicação por escrito como direito humano básico. Stiepan Trofímovitch escreva um número assombroso de cartas para Varvara Pietrovna. São lidas com carinho quase sempre, e têm significado emblemático para o relacionamento. A vontade de expressar tudo que sente, por parte dele, e o carinho que ela nutre pelos papéis indica a natureza dos sentimentos amorosos dos dois. O ex-professor revela-se mais sinceramente por escrito que "falando", pois é com a pena na mão que deixa transparecer afeto pela fidalga, bem como a sua natureza, que é mais sentimental que intelectual. Destaca-se que a capacidade de apresentar evolução interior por escrito é compartilhada por outra personagem dostoievskiana. Diévuchkin, de Gente pobre, é melhor autorrepresentado por escrito: à medida que em que a sua autoestima aumentava, o estilo dele se torna mais refinado.

As epístolas representam canal de opressão, principalmente quando Varvara Pietróvna não emite resposta e deixa o professor em estado de dolorosa expectativa. Também são símbolo de poder e de orgulho quando Chátov sai da universidade. A fidalga escreve ao jovem, mas ele ignora a correspondência e escolhe trabalhar como tutor de crianças. A mulher também é ignorada quando, em São Petersburgo, manifesta intenção de lançar uma revista. Com a publicação, ela pretende entender as polêmicas da época e participar do movimento ideológico, que estava em polvorosa no país. Quer tornar-se socialmente relevante por meio da produção intelectual. Não obtem sucesso. 
Ao escrever para várias pessoas em busca da compreensão do panorama cultural, não obteve respostas. Muitos a acusam de ser capitalista e exploradora devidos aos anseios editoriais. Portanto, tais escritos trazem a marca da incomunicabilidade, pois não geram relações dialógicas. O romance possui várias cartas anônimas, endereçadas principalmente a Praskóvia Ivánova e Varvara Pietrovna. É uma delas que incentiva a mãe de Stavróguin a confrontá-lo publicamente sobre o casamento com a coxa, por exemplo, o que demonstra a força de tudo que é escrito e a tendência desse meio de antecipar o confronto da verdade, mais que revelar a verdade em si.

\subsection{Correspondência do último fim}

Stavróguin não possui pretensões artísticas e, segundo o narrador, não troca muitas correspondências ao longo da vida. Quando vai para São Petersburgo, quase não escreve para a mãe: uma vez por semestre, no máximo. Em diálogo com Dária Pávlovna, declara: “Tinha a intenção de lhe escrever pessoalmente, mas não sei escrever - acrescentou ele com enfado, até mesmo como se estivesse enojado" (DOSTOIÉVSKI, 2004, p. 289). Percebe-se, portanto, que o fidalgo, apesar de ilustrado, não gosta de se expressar por escrito, nem se sente seguro para se comunicar por este meio. Ou seja, só escreve quando extremamente necessário, caso de vida ou morte, literalmente.

Bakhtin (2002, p. 152) considera "as últimas horas de vida antes do suicídio" um dos principais temas de Dostoiévski, principalmente por se tratar de decisão pessoal na qual se podem perceber os "últimos lampejos de consciência" dos personagens (2002, p. 145). Hamlet, em vez de matar imediatamente, encena uma peça e, apenas depois da reação provocada, promove uma carnificina. Stavróguin também promove massacres que acabam por destruí-lo. Revela o processo de autodestruição em carta a Dária Pávlovna, no bilhete suicida e na confissão, que nada mais são que gestos discursivos de transição entre a vida e a morte. Em ambos os casos, há estilização dos crimes cometidos pelos personagens. Os escritos de Stavróguin são o limiar do trespasse.

Stavróguin escreve uma carta para Dária Pavlóvna imediatamente antes do suicídio. Quando o narrador a divulga, expõe uma correspondência pessoal, torna público algo íntimo e sigiloso. É transcrita integralmente no romance, principalmente como forma de demonstrar o fraco domínio de Stavróguin em relação às normas de escrita e estilo. "Eis a carta, palavra por palavra, sem a correção do mais mínimo erro do estilo do fidalgo russo, que não aprendeu completamente a arte da escrita russa, a 
despeito de toda a sua erudição europeia" (DOSTOIÉVSKI, 2004, p. 660). Por meio das palavras dele, porém, é possível realizar uma análise da personagem. A forma truncada pode ser vista como metáfora para o interior confuso do autor-personagem: estudou, mas não consegue construir um argumento escrito; reflete e dialoga sobre o sentido da própria vida, mas não consegue chegar a qualquer conclusão positiva.

Em Os irmãos Karamázov, o Inquisidor afirma que "o segredo da existência humana não consiste apenas em viver, mas na finalidade de viver. Sem uma sólida noção da finalidade de viver o homem não aceitará viver e preferirá destruir-se a permanecer na Terra ainda que cercado só de pães" (DOSTOIÉVSKI, 2008, p. 353). No mesmo sentido, Camus (2010, p. 18) refletiu que alguns morrem pois não consideram que a existência vale a pena, enquanto outros "paradoxalmente, deixam-se matar pelas ideias ou ilusões que lhes são uma razão de viver (o que se denomina razão de viver é ao mesmo tempo uma excelente razão para morrer). Julgo, então, que o sentido da vida é a mais premente das perguntas". Stavróguin é incapaz de se identificar com qualquer resposta possível ao seu drama existencial, apesar de tê-las buscado em todos os lugares. Sobre essa necessidade de respostas, explica o pensador argelino (2010, p. 63): "Posso negar tudo desta parte de mim que vive de nostalgias incertas, menos esse desejo de unidade, esse apetite de resolver, essa exigência de clareza e coesão".

Para pensar na questão da impossibilidade de autorreconhecimento e alcance de sentidos, Camus utilizou-se do conceito de absurdo:

\footnotetext{
Um mundo que se pode explicar, mesmo com raciocínios errôneos, é um mundo familiar. Mas num universo repentinamente privado de ilusões e de luzes, pelo contrário, o homem se sente um estrangeiro. É um exílio sem solução, porque está privado das lembranças de uma pátria perdida ou da esperança de uma terra prometida. Esse divórcio entre o homem e sua vida, o ator e seu cenário é propriamente o sentimento do absurdo (CAMUS, 2010, p. 28).
}

Segundo o filósofo argelino (2010), o sentimento do absurdo não está contido no homem nem no mundo, mas na convivência dos dois. Ele seria o resultado do contato entre um sujeito que apela (pergunta) e um ambiente que silencia, que não lhe fornece respostas. No entanto, apesar de mergulhado em condição precária, o sujeito mantém os gestos da existência, guiado pelo costume. A decisão de retirar-se desse quadro é reconhecimento de que a vida contém um aspecto ridículo e que o sofrimento é inútil.

Quando ainda era um futuro suicida, Stavróguin escreveu: "No ano passado, como Herzen, me registrei como cidadão do cantão de Uri, e ninguém sabe disso. Lá eu 
já comprei uma pequena casa. [...] O lugar é muito aborrecido, tem um desfiladeiro; as montanhas oprimem a visão e o pensamento. É muito sombrio" (DOSTOIÉVSKI, 2004, p. 650). Ele decide se mudar para a Suíça, mas não acredita que o local trará melhoras para sua vida. Será gesto desprovido de sentido, no qual ele afirmará sua condição de moribundo, de cadáver ambulante, morto que anda. A leitura é possível, pois, segundo Bakhtin (2011, p. 133), “a autoconscientização pura da vida é a conscientização da fé (ou seja, da necessidade e da esperança, da não autossatisfação e da possibilidade)”.

O fim da crença no porvir é o fim da essência da experiência vital. Para Camus (2010, p. 46): “Um homem consciente do absurdo está ligado a ele para sempre. Um homem sem esperança e consciente de sê-lo não pertence mais ao futuro". Segundo Bakhtin (2011, p. 115), o ser humano nunca coincide com seu estado presente, e essa projeção do futuro é a essência da existência: "Nunca creio até o fim que sou apenas o que de fato sou aqui e agora, completo-me com o vindouro, o desejado, o devido; só no futuro está o centro de gravidade da minha determinação de mim mesmo". A ideia elucida em parte os pensamentos suicidas do fidalgo, pois aquele que rompe a ligação com essa imagem interior projetada se distancia da vida e se aproxima da morte. "Vivo nas profundezas de mim mesmo com a eterna fé e a esperança na permanente possibilidade do milagre interior de um novo nascimento" (BAKHTIN, 2011, p. 116). Para o teórico, esse sentimento do futuro se assemelha a uma prece, sentimento com o qual Stavróguin não pode comungar, pois não se julga passível de salvação. A escolha do local indica que a mudança de endereço, se tivesse ocorrido, seria um enterro em vida (apesar da negativa dele de ter escolhido intencionalmente um lugar soturno), pois que a personagem declara que jamais sairia de lá para ir a outro lugar. Antes da morte física, considera o fim metafórico de morar à beira de um abismo geográfico.

Destaca-se que Camus (2010, p. 124) descreve a personagem como sendo o “czar na indiferença”. O fidalgo reconhece-se como culpado pelas mortes de Lebiádkina e de Liza. Declara ser assombrado por alucinações. Escreve que em todos os momentos que demonstrou alguma vontade em sua vida, foi para experimentar a força que tinha, para comprovar que ela era ilimitada. Tem plena consciência de que carece de qualquer tipo de ideal. "Sei que preciso me matar, varrer-me da face da terra como um inseto torpe; mas tenho medo do suicídio porque temo mostrar magnanimidade. Sei que isso será mais uma mentira - a última mentira na série infinita de mentiras" (DOSTOIÉVSKI, 2004, p. 652). Até mesmo o fato de ele garantir a Dária Pávlovna que não tem intenções de se matar demonstra que o suicídio é tema constante em sua mente. 
O tédio existencial da personagem vai ao encontro do que refletiu Camus (2010, p. 67): "O homem absurdo não pode fazer outra coisa senão esgotar tudo e se esgotar. O absurdo é sua tensão mais extrema, aquela que ele mantém constantemente com um esforço solitário, pois sabe que com essa consciência e com essa revolta dá testemunho cotidianamente de sua única verdade, que é o desafio".

Enquanto outros personagens do romance possuem convicções políticas, Stavróguin permanece vazio. Incapaz de ligar-se ao seu povo, conforme diálogo com Chátov, torna-se incapaz de acreditar em Deus e de nutrir esperanças em relação à vida:

\begin{abstract}
Pode-se discutir eternamente sobre tudo, mas só consegui extravasar uma negação desprovida de qualquer magnanimidade e de qualquer força. Nem negação como tal consegui extravasar. Tudo foi sempre mesquinho e indolente. O magnânimo Kiríllov não suportou a ideia e matou-se; mas eu vejo que ele foi magnânimo porque não estava em perfeito juízo. Eu nunca posso perder o juízo e nunca posso acreditar numa ideia no mesmo grau em que ele acreditou. Não posso sequer me ocupar com uma ideia naquele grau. Nunca, nunca poderei me matar (DOSTOIÉVSKI, 2004, p. 652).
\end{abstract}

Conforme escreve, as categorias do bem e do mal são indiferentes para ele. Segundo Pareyson (2012, p. 47), "ele ignora completamente qualquer norma, qualquer limite, qualquer valor: a sua liberdade é puro arbítrio, e, não tendo diante de si nenhuma norma a violar, também não tem nenhuma meta a se propor e alcançar, dissolvendo-se na indiferença $[\ldots]$ ”. Decide-se pelo suicídio porque todas as opções de distração haviam se esgotado: "Quando se perderam todas as razões de viver não tem mais sentido humano conservar a vida: este é o motivo de algumas formas de suicídio. A verdadeira morte não é ausência da vida, mas viver na ausência de todo valor" (SCIACCA, p. 218).

Para Shneidman (1984, p. 64) Stavróguin está ciente de sua situação de desesperança, ao dizer que não pode perder a razão, nem se matar, mas ainda assim cometer suicídio. Não por meio de um tiro, o que demandaria ação (identificada com os românticos, ou seja, há associação com o autossacrifício). Permanece passivo até o fim e deixa a corda cometer o ato. Submete-se ao destino e não faz nada para se salvar, assim como não ajuda os outros ao redor. A autoconsciência da falta de sentido da vida retirou dele qualquer motivação para agir positivamente. Segundo Sciacca: “A vida, no seu nada que é a morte, o todo negativo da existência, flui na direção do seu fim, cantando o fim de cada coisa, quase um peregrino direcionado ao lugar de seu repouso" (SCIACCA, 2011, p. 56). Ainda segundo Sciacca, o suicídio daquele que se retira do teatro da vida movido por um sentimento de tédio em relação ao papel representado é estoico, o qual ele define como uma "instância sempre viva na consciência humana 
como instância ética". "Neste caso, aceitar a morte e se dá-la sem paixão, na absoluta indiferença, é um ato simplesmente racional, necessário à autonomia da própria razão e consoante à liberdade diante da vida e da morte" (SCIACCA, 2011, p. 246).

O conteúdo da carta é marcado pelas contradições, bem como pelo anúncio de fatos e ações que não chegam a se concretizar e pela transitoriedade de posicionamentos. Ou seja: a missiva revela como a morte de Stavróguin é análoga à vida: sem convicção. Mesmo que não levasse a sério a proposta de se mudar para a Suíça e que tenha escrito sobre tal decisão para despistar Dácha sobre as suas verdadeiras intenções, fica claro que ele havia considerado a hipótese. A natureza dialógica do fidalgo era disposta a externalizações interiores de imagens e ideias que passavam por sua mente, mas não se firmavam.

\subsection{A confissão de Stavróguin}

Uma visão mais profunda sobre a personalidade de Stavróguin é fornecida na confissão escrita pela personagem e lida pelo monge Tíkhon. Segundo Bakhtin (2011, p. 130), “onde aparece a tentativa de fixar a si mesmo em tons de arrependimento à luz de um imperativo moral, surge a primeira forma essencial de objetivação verbal da vida e do indivíduo (da vida pessoal, isto é, sem abstração de seu agente) - o autoinformeconfissão". Como explicado anteriormente, apesar de o documento só ter sido acrescentado ao romance após o falecimento de Dostoiévski, essa análise trabalha com a publicação post mortem. Na edição analisada neste trabalho, portanto, o texto encontrase localizado após o suicído de Stavróguin, o que é válido para o trabalho, que defende que, na escrita da morte, o discurso sobrevive aos sujeitos que os proferiram. A palavra é semente que pode gerar bons ou maus frutos para a posteridade. $\mathrm{O}$ documento em questão comunga com a ideia de inferno dos vivos não só por transbordar descrença, mas pelo conteúdo expresso, pela profanação mais terrível da inocência e da pureza (violação e morte de Matriócha).

Segundo Joseph Frank (2003, p. 566), a principal diferença entre os escritos iniciais e a versão publicada pela revista diz respeito a Stiepan Trofímovitch. A cena na qual o homem inicia uma odisseia pela Rússia movido pela leitura de trechos e ideias bíblicas foi composta posteriormente à negativa final dos editores. É nesse trecho que ele assume a culpa pela infecção demoníaca do país. O estudioso afirma que a inexistência desse trecho nos escritos iniciais e as notas de Dostoiévski enquanto ainda 
planejava o romance indicam que o autor pretendia atribuir essa responsabilidade a Stavróguin, porém, a retirada da confissão da personagem impossibilitou compreender integralmente as angústias que a assolavam, tornando inverossímil a associação.

O escrito de Stavróguin é mais um teste da força e das ideias da personagem. Bakhtin considera o documento um exemplo de menipeia (2002, p. 157). Shneidman (p. 67) explica que a presença desse capítulo muda radicalmente a ênfase da narrativa. Sem a confissão, o maior crime de Stavróguin é a cadência de catástrofes gerada pela influência de suas emoções e pensamentos. Com a confissão, o crime maior se torna o abuso de Matriócha, que resulta no suicídio da menina, ato semelhante ao assassinato. A alucinação que ele afirma ver é concretização das atitudes de Stavróguin perante os outros e o medo do mal e do demônio que ele percebe em si mesmo. Sobre as confissões, Bakhtin discorre: "O elemento essencial, constitutivo dessa forma é o fato de que se trata precisamente de uma auto-objetivação, de que o outro é excluído com sua abordagem particular, privilegiada; aqui, só a relação pura do eu consigo mesmo é o princípio da enunciação" (BAKHTIN, 2011, p. 130, grifo do autor).

O teórico russo (2011, p. 135) explica ainda que um autoinforme-confissão não pretende construir um todo biográfico do sujeito. Nesse sentido, o escrito de Stavróguin se concentra principalmente no episódio em que, levado pelo tédio, viola a pequena Matriocha. Por causa da repulsa que o aflige ao ver a menina sorrir durante o ato sexual, sente medo pela primeira vez na vida. $O$ fato de a garota ter demonstrado forte envolvimento emocional em relação a ele desperta a vontade de matá-la. Não precisa ir adiante com o propósito, pois ela mesmo se suicida. "Mas por volta das onze horas uma criada chegou da Gorókhovaia, da parte da senhoria, com a notícia de que Matriócha havia se enforcado" (DOSTOIÉVSKI, 2004, p. 674). Antes de fazê-lo, é tomada por delírios, durante os quais repete incessantemente que matou Deus. Devido ao profundo estado de horror no qual Matriócha se descobre, o reencontro com ela é o momento mais marcante da vida do protagonista dostoievskiano. Em Os irmãos Karamázov, Ivan descreve o sofrimento de crianças como o maior sinal de que o mundo não faz sentido. A ofensa é tão terrível que castigar os malfeitores era um ato sem efeito. "Para que preciso de inferno para os carrascos, o que o inferno pode corrigir quando aquelas crianças já foram supliciadas?” (DOSTOIÉVSKI, 2008, p. 339).

Segundo Shneidman (1984), o suicídio de Matriócha é um ato desesperado. Seu mundo é despedaçado, mas seus valores morais éticos permanecem inalterados. Considera ter cometido um grande pecado. Matriócha representa a bondade e a 
inocência. Por causa disso, ambos os personagens parecem concordar que a atitude correta a ser adotada por ela deveria ter sido a da violação sem a possibilidade do prazer. Quando ela beija Stavróguin com desejo, ela escolhe o Demônio em detrimento de Deus. Stavróguin aqui é a própria representação de Satanás. Não é coincidência, portanto, o fato de ter sido essa a situação a causar-lhe medo pela primeira vez. Dostoiévski parece afirmar que Deus é infinitamente maior que o mal e que o demônio impreterivelmente tremerá diante da manifestação Dele.

Frank (2003, p. 636) afirma que apesar do desejo de "transcender o humano, de arrogar-se o poder supremo sobre a vida e a morte [...] Stavróguin não consegue eliminar inteiramente seu sentimento da diferença entre o bem e o mal. Esse sentimento irreprimível irrompe de seu subconsciente”. Stavróguin sonha com o quadro de Claude Lorrain Ácis e Galateia e essa visão de paraíso terrestre o deixa feliz. Como um condenado aos infernos a quem a esperança de rever os céus deveria ser abandonada, porém, logo se lembra da natureza sombria de sua condição: "Mas então uma pequena aranha vermelha, associada no subconsciente de Stavróguin à morte de Matriócha, substitui essa abençoada visão do Éden" (FRANK, 2003, 636). Ele vê, em pensamento, a menina e o seu gesto de ameaça com o punho. Não consegue tolerar a lembrança do próprio mal, mas também não a reprime, o que demonstra que por breve momento chega a considerar que a expiação de seus pecados o ajudará a escapar da loucura.

Para Bakhtin (2011, p. 132), no cerne do gênero “o auto informe-confissão está cheio de necessidade de perdão e redenção como dádiva absolutamente pura (não por méritos), de graça e felicidade axiologicamente oriundas do outro mundo". Segundo Frank (2003), ao mesmo tempo que a confissão demonstra que Stavróguin se atormenta interiormente pelos seus atos, não é suficiente para que supere seu orgulho e aceite a possibilidade de renovação. Tíkhon nota no escrito a mesma manifestação da volúpia que o outro sentiu ao realizar atos perversos. "Tíkhon percebe que Stavróguin nunca alcançará por si mesmo a verdadeira humildade de um arrependimento genuíno; assim, sua necessidade de sofrimento e martírio só pode ocasionar provocações cada vez mais calamitosas" (FRANK, 2003, 638). Tíkhon sugere que o outro faça um voto, se coloque sob a proteção de um monge e comece a trilhar um caminho até Cristo.

Stavróguin escreve que a lembrança do episódio lhe é insuportável. Mas o que o perturba não é o crime, a gravidade do ato cometido, nem a possibilidade de ser mandado para a Sibéria. Não sabe dizer se sente remorso e não perde tempo refletindo se algum dia o teria experimentado. A única coisa que o perturba é a lembrança do gesto 
de ameaça feito por Matriócha. Não há ódio na recriminação de Matriócha, apenas desespero. E mesmo se o sentimento existisse, provavelmente não o perturbaria. O que deixa Stavróguin transtornado é exatamente o gesto de censura aflita (na qual ainda pode haver amor, grandeza, pureza) ausente de raiva manifestado pela garota. Matriócha havia perdido o que há de mais essencial no ser humano, a possibilidade de contato com o bem e com o transcendental, por causa dele. Ao se rebelar, ela não só o recrimina, como martiriza a si mesma. Matriócha percebe naquele momento que se Deus morreu, eles eram os culpados, portanto, não há razão para estar viva. Ao levantar os punhos, Matriócha revela a Stavróguin a profundidade do lodo no qual ele está mergulhado, ideia incompreensível para ele, já que a personagem não acreditava em Deus. Stavróguin se vê em um não-lugar em relação ao divino, pois antes de Matriócha ele nunca havia existido e, depois, ele já havia deixado de existir.

Segundo Bakhtin (2011, p. 133), “onde eu não coincido absolutamente comigo mesmo, abre-se espaço para Deus". Stavróguin fechou a porta da própria redenção por meio do ensimesmamento. Como poderia ter matado Deus se não acreditava nele? Se realmente tiver matado Deus, é porque ele existia antes. Se existia, é porque Stavróguin cria intimamente nele e a ideia o aterrorizava tanto, que não conseguia compreendê-la. Kiríllov compreendeu o conflito de Stavróguin e descreveu-o em diálogo com Vierkhoviénski: "Stavróguin se crê, crê que não crê. Mas se não crê, então não crê que não crê." (DOSTOIÉVSKI, 2004, p. 597). Por não conseguir resolver o dilema divino - acreditava ou não em Deus? Queria se redimir ou sofrer censura eterna após a violação de Matriócha? - Stavróguin pende o pensamento para o outro extremo e passa a se preocupar com o demônio. Diante da possibilidade de ter sido visitado por um, pergunta ao místico Tíkhon se "é possível crer no demônio sem crer inteiramente em Deus" (DOSTOIÉVSKI, 2004, p. 661). Nesse trecho, percebe-se um estreito diálogo com a teologia ortodoxa, para qual a entidade existia de fato, "não como símbolo, mas como materialidade" (PONDÉ, 2003, p. 104):

Stavróguin contou que sofria, sobretudo às noites, de uma espécie de alucinação, que às vezes via e sentia ao seu lado uma criatura malévola, zombeteira e "sensata", com diferentes caras e diferentes caracteres, mas ela é a mesma, e eu sempre fico furioso. (DOSTOIÉVSKI, 2004, p. 659)

Sobre a possibilidade de o demônio apresentar facetas humanas, Ivan Karamázov afirmou: "Acho que se o Diabo não existe e, portanto, o homem o criou, então o criou a sua imagem e semelhança” (DOSTOIÉVSKI, 2008, p. 330). O meneio 
de cabeça da menina é uma verdadeira manifestação do Divino na vida dele e, mesmo assim, segundo a interpretação da personagem, foi assaz breve, efêmero, pueril e inútil para levá-lo à conversão. Stavróguin não consegue entender a escolha absoluta e sem sentido de Matriócha e muito menos aceitar a ideia de uma transcendência que se manifestasse de forma tão ridícula. O conflito de Stavróguin resume bem a crença de Dostoiévski e os preceitos da religião ortodoxa: é impossível compreender Deus por meio da razão e enxergá-lo com olhares terrenos. A impossibilidade do pensamento assenta-se de forma tão profunda em Stavróguin, que ele busca formas diversas de lidar com ela. Escrever uma confissão foi a principal delas. Citado por Camus (2010, p. 154), o filósofo Søren Kierkegaard afirma: "Devemos ferir de morte a esperança terrena, porque só assim nos salvamos pela esperança verdadeira” (2010, p. 154).

Segundo Bakhtin (2011, p. 132), na confissão “o pedido e a súplica permanecem abertos, inacabados, como que se fragmentam em direção ao futuro não predeterminado do acontecimento. É o momento propriamente confessional do autoinforme-confissão". A intenção é imprimir trezentas cópias do documento e distribuí-lo pela Rússia. Ele acredita que a censura do olhar das pessoas que soubessem do crime poderia lhe despertar algum nível de alívio. O desprezo alheio justificaria e explicaria de alguma forma o desprezo que ele sente em relação a tudo e a todos. A confissão deveria ser divulgada para a expiação pública dos pecados. Bakhtin (2010a, p. 63) explica que "para Dostoiévski, só na forma de declaração confessional de si mesmo é dada a última palavra sobre o homem, realmente adequada a ele".

Tíkhon compreendeu a necessidade de exposição: "Quer dizer, o ódio deles suscitará o seu, e odiando, o senhor se sentirá mais aliviado do que se recebesse compaixão da parte deles?” (DOSTOIÉVSKI, 2004, p. 681). Fica bem claro que Stavróguin não sabe lidar com a virtude e a moralidade. Ainda de acordo com Pondé, pensamento que se aplica perfeitamente a Stavróguin: "Viver o mal é viver nessa agonia constante, na polifonia infernal, na insegurança absoluta em relação ao que se é" (2003, p. 192). Stavróguin conheceu o mau tanto pela agonia interna, como pela experiência com atos condenáveis: assassinatos, roubo, escândalos, libidinagem. A escrita do documento não o ajuda a resolver nenhuma dessas questões. Segundo Camus (2010, p. 126): "Uma obra absurda [...] não dá respostas".

Para o escritor argelino (2010, p. 113), “o criador absurdo não se apega à sua obra" (p. 113), o que indica o porquê de Stavróguin não ter tentado embelezar o documento, escrevê-lo de forma mais atraente. Ao ler o documento, o místico o 
repreende pela pobreza de estilo e recomenda-lhe algumas correções textuais. O fraco domínio da desenvoluta escrita vai ao encontro do que Bakhtin (2011, p. 159) afirma sobre as confissões: "Em geral, no autoinforme-confissão não há tarefa artística, e por isso valores puramente estéticos do todo, do todo dado e do presente". O narrador de $O s$ demônios também destaca o fato de o documento não ser ter sido escrito em linguagem clara e o fato de Stavróguin se comunicar de forma incompetente e falha, muito aquém daquela que se esperaria de um burguês com bagagem de estudos. Segundo Frank (2003), no documento pode-se perceber a busca de uma fé absoluta que foi corrompida pela ilustração europeia e ainda não pode ser recapturada apesar da necessidade angustiante de uma "verdade nova".

A incomunicabilidade anunciada dialoga com a ortodoxia. Segundo Pondé, na religião ortodoxa "só se pode falar do que se sabe por experiência própria" (2003, p. 100). Stavróguin nunca teve experiência divina, nunca sentiu a presença de Deus, o que traz luz sobre o fato de que todas as tentativas de problematizar a questão, por parte dele, se darem de forma fragmentada e pouco coesa. Segundo Pareyson (2012, p. 51), há um componente de farsa onde supostamente deveria ser lugar de transparência e honestidade. Stavróguin não é completamente franco em sua confissão, é condescendente com os desvios morais, há mesmo volúpia em relação a eles. "O pretenso arrependimento de Stavróguin não é senão mescla de tortura e gozo, autodenigração [sic] e complacência, aviltamento e soberba, humilhação e orgulho". Shneidman (1984, p. 67) destaca que o nome de Stavróguin (chifre/portador da cruz) demonstra a natureza contraditória do jovem: aquele que finge estar pronto para carregar a cruz, mas em vez disso, revela o chifre.

Segundo Bakhtin (2010a, p. 284) “a confissão de Stavróguin, como a confissão de Hippolit e a do homem do subsolo, é uma confissão com a mais intensa orientação voltada para o outro, sem o qual o herói não pode passar, mas o qual ele odeia ao mesmo tempo e cujo julgamento não aceita, por isso, a confissão de Stavróguin [...] carece de vigor conclusivo". Breger (1989) considera que o romance vai expondo progressivamente o aspecto ridículo de Stavróguin. Liza diz que se sentia atraída por ele como a uma grande aranha que ela associa aos maiores horrores. Após passar a noite com ele, ela se decepciona e seu lado maligno parece um inseto ridículo, como a pequena aranha vermelha que ficou na mente dele por causa do crime envolvendo Matriócha. Para Breger (1992), os dois crimes cometidos que ganham destaque no romance, o ataque à Matriócha e o assassinato à esposa louca foram na verdade 
patéticos, se for levado em consideração que ambas as vítimas são indefesas e que ele não precisa de muita coragem para dar cabo das situações.

A concretização das mortes pelas quais foi responsável faz com que as alucinações dele piorem e que ele decida se retirar da sociedade. Compra uma casa à beira de um desfiladeiro e pretendia se mudar permanentemente para lá, intenção descrita na carta que Dária Pavlóvna recebe no dia do suicídio da personagem. Enquanto ela se prepara para segui-lo, descobre que ele havia tirado a própria vida. $\mathrm{O}$ romance Os demônios termina, portanto, de forma abrupta. $\mathrm{O}$ romance morre quando a personagem se retira, em estilização formal do suicídio.

\subsection{Bilhete suicida: o a(u)tor sai de cena}

Stavróguin se enforca. No ato II, cena 2, Hamlet também considera a possibilidade de tirar a própria vida e aproxima a questão da morte voluntária ao Divino, elemento importante na morte de Stavróguin: "Se esta poluída, completamente poluída carne pudesse ser derretida, ser evaporada e dissolvida num orvalho! Por que o Todo-Poderoso fixou suas leis sobre o suicídio?” (SHAKESPEARE, 2007, p. 22). Em Os irmãos Karamázov, Dostoiévski torna explícita a relação entre Hamlet e o tema da morte voluntária durante o julgamento de Dmitri, na fala do promotor:

Reparem, senhores, reparem como os jovens se matam em nosso país: oh, sem nenhuma daquelas perguntas hamletianas do tipo: "O que haverá além?", sem qualquer indício de tais perguntas, como se tudo o que diz respeito ao nosso espírito e ao que nos espera no além-túmulo estivesse sepultado há muito tempo na natureza desses jovens, sepultado e coberto de areia (DOSTOIÉVSKI, 2008, p. 898).

Não há descrição do momento da morte por parte do narrador, ou seja, ele não narra o momento em que Stavróguin se dirige à forca, nem os pensamentos dele antes do fim. O romance se concentra em narrar como o suicídio é descoberto pelas pessoas de sua casa, bem como o clima de medo que antecedeu e acompanha a descoberta. $\mathrm{O}$ corpo do fidalgo é encontrado quando Dacha conta os planos do jovem para a mãe dele. Vão se preparar para a partida, mas ficam sabendo que Stavróguin havia acabado de chegar em casa. O criado Aleksiêi Iegóritch, contrariando ordens recebidas pelo amo, informa que 'Nikolai Vsievolódovitch chegara 'de supetão' de manhã cedo, de trem, e estava em Skvoriéchniki, mas 'com tal aspecto que não responde às perguntas, passou por todos os quartos e trancou-se na sua metade..."” (DOSTOIÉVSKI, 2004, p. 652). Portanto, a última aparição, como a primeira, é inesperada. 
Quando as duas mulheres chegam à parte da casa que pertence a Stavróguin, encontram todas as portas abertas, mas nenhum sinal do fidalgo. $\mathrm{O}$ clima de curiosidade permite a quebra das regras. Os criados adentram na parte proibida: um deles sugere que o procurem no mezanino, onde também não é encontrado. Uma pessoa indefinida pergunta se ele não teria ido para "lá", e aponta para o sótão. Dária Pávlovna estremece diante da possibilidade e Varvara Pietrovna se recusa a ir naquela direção, pois o filho não teria motivos para se esconder no local. Apesar da negativa, vai até o sótão, onde desmaia imediatamente:

O cidadão do cantão de Uri estava pendurado ali mesmo atrás da porta. Em uma mesinha havia um pequeno pedaço de papel com estas palavras escritas a lápis: "Não culpem ninguém, fui eu mesmo". Ali mesmo na mesinha havia um martelo, um pedaço de sabão e um prego grande, tudo indica que trazidos de reserva. O forte cordão de seda, pelo visto escolhido e comprado de antemão e com o qual Nikolai Vsievolódovitch se enforcou, estava abundantemente untado de sabão. Tudo significava premeditação e consciência até o último minuto (DOSTOIÉVSKI, 2004, p. 653).

O romance acaba com as palavras do narrador, segundo as quais os médicos que realizaram a autópsia "negaram total e categoricamente a hipótese de loucura" (DOSTOIÉVSKI, 2004, p. 653). Sobre Dostoiévski e o suicídio, Paperno (1997, p. 139) relata que nas notas para $O$ adolescente, Dostoiévski classifica o ato como busca metafísica. O autor destaca o impulso autoral acometido pela maioria dos futuros mortos: "As pessoas se matam por várias razões; elas também escrevem confissões por motivos complicados, não apenas por vaidade. Mas é possível encontrar características comuns, por exemplo, que em tal momento todo mundo sente a necessidade de escrever" 39 . O bilhete suicida é uma das possibilidades do "ser que sabe que morre e que continua discursando", uma forma de "experienciação da ausência de si mesmo no mundo" (SILVA Jr., 2011, p. 41). A anotação à véspera da morte é tentativa do morto de vencer a própria morte, de sobreviver discursivamente. É tentativa do morto de deixar a própria versão sobre os fatos, dizer a última palavra. É característica da tanatografia, essa modalidade de escrita que "se confronta com o olhar do vivo na condição de alguém que vê o próprio acabamento" (SILVA Jr., 2011, p. 68).

Segundo Irina Paperno (1997), a nota suicida era vista como uma fonte de acesso ao significado do ato de retirar-se do mundo e da experiência de morrer. Porém, um sentimento muito comum à leitura das mensagens escritas é a decepção, pois muitas

\footnotetext{
39 "People kill themselves for a host of reasons; they also write confessions for complicated reasons, not out of vanity alone. But one can also find common features, for example, that as such a moment everyone feels the need to write."
} 
delas possuem conteúdo banal e pouco elucidativo. Para a estudiosa, um fraco poder de comunicação está associado aos mortos voluntários, na maioria das vezes compartilhado pelos bilhetes deixados pelos suicidas. Segundo Shneidman (1984), um suicídio de sucesso leva o seu segredo para o túmulo, pois não é permitido que um homem experimente a morte enquanto vivo. O estudioso cita trecho de Anna Karenina, quando Levin assiste à morte do próprio irmão e inveja a experiência do moribundo, que agora tinha o conhecimento da morte, o que lhe era negado.

Segundo Paperno (1997, p. 106), na Rússia do século XIX, como no resto do mundo, as notas suicidas eram entregues aos médicos-legistas. Se atualmente é comum esconder as últimas mensagens dos mortos da imprensa, naquela época a publicação delas era comum. A prática começou na década de 1860 e prosseguiu até 1917. A ideia de que tais bilhetes eram de domínio público vinha do costume de associar o suicídio às doenças mentais, portanto, assim como o corpo, o bilhete devia ser tratado como objeto de investigação a ser dissecado para a descoberta da patologia em questão. Dessa forma, o que era matéria intrinsecamente do domínio particular, se tornava público. Eram plenos documentos de morte.

O bilhete de Stavróguin é exemplo de publicação de um escrito íntimo, já que tem como destinatários imediatos a família e os servos mais próximos e acaba sendo publicado em um romance. Vale destacar que o costume de acionar os médicos em caso de suicídio está presente em Os demônios. Diante da impossibilidade de contar a própria morte, pelo menos de acordo com os padrões de verossimilhança e realismo adotados pela narrativa de Os demônios, os legistas são acionados para tentar identificar a causa que teria levado Stavróguin a se matar. Percebe-se a tentativa não-sucedida de dizer a última palavra sobre a morte alheia por meio da ciência. Paperno (1997, p. 115) explica que muitos suicidas, da Rússia do XIX, não entendiam exatamente o motivo que os levavam ao ato voluntário. Ela conta que, para muitos, a mensagem mais importante deixada pelo morto não era o bilhete, mas o corpo.

Breger (1992) acha bastante relevante que Stavróguin tenha crescido sem pai e sob as fracas relações de amor com a mãe, influenciadas por alta dose de idealização e pouca realidade, para a formação da personalidade dele: sempre exibindo uma faceta falsa. Para o estudioso, essa relação frouxa com a mãe, de pouco afeto na infância, influenciou na forma que ele se relaciona com as mulheres: ou procurando pelo afeto delas sem conseguir retribuir (Dária Pávlovna e Liza) ou elas se tornam objeto de sua ira assassina (Matriócha e Mária Lebiádkina). Ele também acha relevante ele ter se 
suicidado na casa da mãe, não em outro lugar. Segundo Pareyson, “os espaços de Dostoiévski são íntimos, espirituais, humanos, e símbolo disso é a sua angústia, que os torna cheios e apinhados" (PAREYSON, 2012, p. 30). Sobre o espaço em Dostoiévski, Bakhtin (2010a, p. 172) explica que Dostoiévski concentra a ação no limiar. O sótão que só podia ser acessado por meio de uma escadinha íngreme confirma essa tendência.

Segundo Camus (2010, p. 105), “carecer de esperança não equivale a se desesperar". O suicídio de Stavróguin é feito de forma discreta e quase anticlimática, o que torna o fato mais assustador. Não há narrativa de como ele tira a própria vida. $\mathrm{O}$ narrador só revela "a cena do crime". Segundo Bakhtin, o ato repentino está de acordo com a tendência de Dostoiévski de representar a ação de forma bastante concentrada. Se a decisão dele parece surpreendente, apesar de o ato ter sido premeditado, é porque se trata de um tempo de crise, próprio ao limiar e à praça pública, "no qual o instante se iguala aos anos, aos decênios e até a um bilhão de anos" (BAKHTIN, 2010a, p. 196). Pareyson (2012, p. 31) destaca a passagem acelerada do tempo em que cada minuto é concentrado e dotado de possibilidade de reviravoltas. "Cada dia é uma época inteira, cada hora é um grupo de acontecimentos, cada minuto é grávido de destino."

O suicídio de Stavróguin levanta vários problemas, sem respondê-los completamente, relativos às questões de: a) Forma: é personagem de romance, mas contém elementos de tragédia e drama; b) Religioso: acredita em Deus?; c) Social: Foi pupilo do protossocialista da década de 1840, o "pai"; d) Psicológico: tem visões ou não?; e) Político: toma parte em atividades revolucionárias, é niilista; f) Afetivo: não consegue amar (e portanto, habita o inferno do stárietz Zóssima); g) Cognitivo: Precisa de outros para conseguir expressar o próprio pensamento, mas não se convence; $h$ ) Moral: sente remorso por ter violentado uma garota, mas também sente volúpia ao lembrar das suas ações maléficas. Paulo Bezerra (2010, p. 12) afirma que a multiplicidade de interrogações condiz com o discurso polifônico, pois este é "sempre o discurso em aberto, o discurso das questões não resolvidas".

A morte de Stavróguin sucede da mesma forma que a vida dele, de forma confusa, inacabada, polifônica, indecisa. Suicida-se por causa de elementos diversos: o primeiro contato com a sensação de medo, uma constante sensação de apatia e desinteresse pela vida, o desejo de ser censurado pelos atos ignominiosos ao mesmo tempo em que se ridiculariza por isso, a vergonha do arrependimento (não acompanhada da vergonha do crime), a necessidade de ser salvo por uma cruz na qual nunca acreditou. Dentre esses motivos, todos, e nenhum em particular, causaram o 
aniquilamento de Stavróguin. Para Bakhtin (2010a, p. 326), o interesse dostoievskiano pelo suicídio está relacionado ao fato de essas mortes serem "elos numa cadeia consciente, na qual o homem conclui a si mesmo de dentro para fora". Stavróguin acredita no Diabo, mas não em Deus, o que indica a impossibilidade de sua salvação. A personagem tem, inclusive, visões do demônio, que é seu lado maligno personificado. Dária Pávlovna pede a Deus que o proteja contra o demônio dele, ao que Stavróguin disse: “Oh, que demônio o meu! É simplesmente um demoninho pequeno, torpezinho, escrofuloso, gripado, daqueles fracassados” (DOSTOIÉVSKI, 2004, p. 291).

O protagonista se mata, ou melhor, retira-se do enredo após perambular como morto-vivo enfastiado por todo o romance. Ao longo do enredo, o jovem se revela um passante entediado e desinteressado pela própria existência. Enquanto vivo, é alguém que dialoga para tentar compreender os próprios pensamentos e que age para estudar como se sente em situações variadas. Stavróguin: espectador de si mesmo. Depois de morto, um cadáver que deixa para trás um cenário a ser decifrado: uma carta farsesca, com a qual pretende despistar os rumos de seu futuro; uma forca que mais parece palco; um bilhete breve, mas pleno de performance: decisivo e direto como o seu ato final. Stavróguin, o defunto-a(u)tor. 


\section{CONSIDERAÇÕES FINAIS}

O narrador de Os demônios, ao relatar os acontecimentos ocorridos na província, não quer se imortalizar, não parece movido pela vaidade, quer apenas contar uma história notável. Não só porque presenciou alguns momentos, mas pela natureza horripilante e excessiva da crônica. $\mathrm{O}$ narrador começa com uma biografia e encerra o texto com uma morte, seguindo uma trajetória linear. Registra a tragédia três meses após o fim.

A vida de Stavróguin só gera morte e destruição. Do mesmo modo, a morte da personagem é completamente estéril, não lança frutos. Como o personagem não se reconcilia com qualquer convicção, ideia ou crença, não consegue encontrar a própria voz e, portanto, se mata. Ou melhor, retira-se da própria arena infernal, constituída pela consciência de sua situação absurdamente desesperançada.

As influências culturais sofridas pela Rússia do século XIX foram as mais diversas e conflitantes. Paralelamente, os processos de escrita e publicação do romance Os demônios sofreram vários fatiamentos e edições. Dostoiévski planejou que o protagonista fosse uma figura caótica e confusa, mas essas características acabaram ganhando mais força que deveriam por causa da censura. A personalidade de Stavróguin, tal como uma colcha de retalhos, acaba por refletir a época e o contexto de sua criação. Nota-se que a fragmentação psicológica de Stavróguin encontra eco também na forma entrópica e caótica de Os demônios.

Stavróguin, personagem cuja personalidade se fragmenta pelas dúvidas religiosas, pela ausência de qualquer crença positiva, pela incapacidade de amar, pelas influências "perniciosas" do ocidentalismo e do radicalismo russo, demonstra esse estilhaçamento pessoal também estruturalmente. Além de não conseguir expressar-se sozinho, tendo necessitado de outras figuras para dar voz ao seu discurso interior, é fruto de um processo de composição despedaçado. As comunicações realizadas por Stavróguin expressam instâncias de sua autoconsciência, nunca um posicionamento imutável. Tem o próprio fidalgo como mais importante interlocutor. O conteúdo dos escritos e diálogos expressam o inacabamento do homem vivo, sobre quem é impossível dizer a última palavra, bem como apontam os outros personagens como adversários da luta que Stavróguin provocou para brigar consigo mesmo. Enquanto Stavróguin fala e tenta compreender a si mesmo nos outros, vive. Em diálogo, há contato com o mundo 
exterior, e portanto, continua escutando os ecos distantes do passado para ver se ainda pode se surpreender e se interessar por alguma coisa. Na três vezes que se dispõe a escrever, porém, aproxima-se radicalmente da morte. Ato pessoal, a escrita faz com que lide intimamente com o eu interior e obriga-o a reconhecer-se exaurido, sem mais nada a expressar, nem concretizar.

Em Os demônios, não há mortos que voltam para dialogar no romance, nem interação com o além. No entanto, o príncipe das trevas dostoievskiano tem aspecto agradável e vale-se de palavras para erguer pontes entre os dois lados do rio da vida, bem como levanta a questão da responsabilidade em proferi-las. As formas por meio das quais elas são expressas, portanto, é significativa. Se Hamlet valia-se do solilóquio como forma de expressão primordial (foram sete ao longo da peça, nos quais ele vai se reconstituindo a cada fala), Stavróguin é todo diálogo e ação, mesmo quando opta por silêncio, mesmo quando é passivo. Por ser a consciência que mais influenciou as outras, direta ou indiretamente, os jogos de palavras centrados em torno dele constituíram o libreto da ópera infernal da qual ele foi regente e que todos os personagens formaram estando juntos. 


\section{REFERÊNCIAS BIBLIOGRÁFICAS}

\section{LIVROS}

AGOSTINHO, Santo. A Cidade de Deus. São Paulo: Editora das Américas, 1961, v. 1.

ALIGHIERI, Dante. A Divina Comédia. 15ª ed., São Paulo: editora 34, 2008.

ALTSHULLER, Mark. "The Transition to The Modern Age: Sentimentalism and Preromanticism, 1790-1820". In: MOSER, Charles A. The Cambridge History of Russian Literature. Cambridge: Cambridge University Press, 1992, p. 92-135.

ARIÈS, Philippe. História da morte no Ocidente: Da Idade Média aos nossos dias. São Paulo: Ediouro, 2003.

ARISTÓTELES. Ética a Nicômaco. São Paulo: Editora Abril Cultural, 1973.

ARISTÓTELES. The Nicomachean Ethics. New York: Dover, 1998.

AUERBACH, Erich. Mimesis: A representação da realidade na literatura ocidental. $4^{\mathrm{a}}$ ed., São Paulo: Perspectiva, 2001.

BAKHTIN, Mikhail. "Sobre Bobók”. In: DOSTOIÉVSKI, Fiódor. Bobók. São Paulo: editora 34, 2012, p. 69-85.

A Cultura popular na Idade Média e no Renascimento: O contexto de François Rabelais. Brasília: Editora da Universidade de Brasília, 2008.

Estética da criação verbal. São Paulo: Martins Fontes, 2011.

Problemas da poética de Dostoiévski. São Paulo: Ed. Forense, 2002.

Problemas da poética de Dostoiévski. São Paulo: Ed. Forense, 2010a.

Editora Hucitec, 2010b.

Questões de literatura e estética: A teoria do romance. São Paulo:

BEZERRA, Paulo. Bobók. Tradução e análise do conto. São Paulo: editora 34, 2005.

"Um romance profecia”. In: DOSTOIÉVSKI, Fiódor. Os demônios. São Paulo: editora 34, 2004, p. 697.

BÍBLIA DE JERUSALÉM. São Paulo: Paulus, 2002.

BLANCHOT, Maurice. O espaço literário. Rio de Janeiro: Rocco, 2011.

BLOOM, Harold. The Anatomy of Influence: Literature as a Way of Life. New Haven: Yale University Press, 2011.

BØRTNES, Jostein. “The Literature of Old Russia, 988-1730”. In: MOSER, Charles A. The Cambridge History of Russian Literature. Cambridge: Cambridge University Press, 1992, p. $1-44$.

BREGER, Louis. Dostoevsky: The Author as Psychoanalyst. New York: New York University Press, 1989.

BUSHKOVITCH, Paul. A Concise History of Russia. New York: Cambridge Univerty Press, 2012.

CALVINO, Italo. As cidades invisíveis. São Paulo: Companhia das Letras, 1990.

. "Leveza". In: CALVINO, Italo. Seis propostas para o próximo milênio. São Paulo: Companhia das Letras, 1990, p. 15-41.

CAMUS, Albert. O mito de Sísifo. 8ª ed., Rio de Janeiro: Record, 2010. 
CANDIDO, Antonio. O discurso e a cidade. $3^{\mathrm{a}}$ ed., Rio de Janeiro: Ouro Sobre Azul, 2004.

CHANCES, Ellen. "The Superfluous Man in Russian Literature". In: CORNWELL, Neil. The Routledge Companion to Russian Literature. New York: Routledge, 2001, p. 111-22.

CHESTERTON, G. K. Ortodoxia. São Paulo: Mundo Cristão, 2008.

CIORAN, Emil. "Rencontres avec le suicide". In: CIORAN, Emil. Le mauvais demiurge. Paris: Gallimard, 1969, p. 73-99.

COATES, Ruth. "Religious Writing in Post-Petrine Russia". In: CORNWELL, Neil. The Routledge Companion to Russian Literature. New York: Routledge, 2001, p. 12-25.

COIMBRA, Diógenes. Suicídio meritório: Reflexões acerca da morte voluntária desde um ponto de vista ético-negativo. Brasília, 2011. 170 f. (Dissertação de mestrado). Universidade de Brasília, Programa de Pós-Graduação em Filosofia.

DAVIES, Douglas. A Brief History of Death. Malden, MA: Blackwell, 2005.

DOSTOEVSKY, Fyodor. The Adolescent. New York: Vintage, 2004.

DOSTOIÉVSKI, Fiódor. Bobók. São Paulo: editora 34, 2005.

Bóbok. São Paulo: editora 34, 2012.

Crime e castigo. São Paulo: editora 34, 2001.

ridículo. São Paulo: editora 34, 2003 a.

Duas narrativas fantásticas: $A$ dócil $e$ $O$ sonho de um homem

Gente pobre. São Paulo: editora 34, 2009.

. Memórias do subsolo. São Paulo: editora 34, 2000.

. O eterno marido. São Paulo: editora 34, 2003b.

O idiota. São Paulo: editora 34, 2002.

Os demônios. São Paulo: editora 34, 2004.

. Os irmãos Karamázov. São Paulo: editora 34, 2008.

Um jogador. Trad. Boris Schnaiderman. São Paulo: editora 34, 2004b.

DURKHEIM, Émile. O suicídio: Estudo de sociologia. São Paulo: WMF Martins Fontes, 2011.

FRANK, Joseph. As sementes da revolta: 1821-1849. $2^{\text {a }}$ ed., São Paulo: Editora da Universidade de São Paulo, 2008.

São Paulo, 2007.

O manto do profeta: 1871 a 1881. São Paulo: Editora da Universidade de São Paulo, 2002.

Os anos de provação: 1850 a 1859. São Paulo: Editora da Universidade de

São Paulo, 2003.

Os anos milagrosos: 1865 a 1871. São Paulo: Editora da Universidade de de São Paulo, 2002.

Os efeitos da libertação: 1860 a 1865. São Paulo: Editora da Universidade

FREEBORN, Richard. "The Classic Russian Novel". In: CORNWELL, Neil. The Routledge Companion to Russian Literature. New York: Routledge, 2001, p. 101-10.

"The Nineteenth Century: The Age of Realism, 1855-80". In: MOSER,

Charles A. The Cambridge History of Russian Literature. Cambridge: Cambridge University Press, 1992, p. 248-332.

FREUD, Sigmund. Além do princípio de prazer. Rio de Janeiro: Imago, 1998. 
2011.

O mal estar da civilização. São Paulo: Companhia das Letras/Penguin,

GOMIDE, Bruno. "Sobre Augusto Meyer e Dostoiévski". Revista de Letras (Curitiba, 1996), v. 66,2005 , p. 31-44.

Da estepe à caatinga: o romance russo no Brasil (1887-1936). São Paulo: Editora da Universidade de São Paulo, 2011.

GROSSMAN, Leonid. Dostoiévski artista. Rio de Janeiro: Civilização Brasileira, 1967.

HOMERO. Odisseia. São Paulo: Companhia das Letras/Penguin Classics, 2011.

LANTZ, K. A. The Dostoevsky Encyclopedia. Westport: Greenwood Press, 2004.

LEATHERBARROW, William. Dostoevsky's The Devils: A Critical Companion. Evanston: Northwestern University Press, 1999.

LUCIANO. Diálogo dos mortos. Brasília: Editora da Universidade de Brasília, 1998.

LUKÁCS, György. "Dostoiévski” In: LUKÁCS, György. Ensaios sobre literatura. Rio de Janeiro: Civilização Brasileira, 1968, p. 155-73.

"Narrar ou descrever". In: Lukács, György. Marxismo e teoria da literatura. São Paulo: Expressão Popular, 2010, p.149-86.

MACHADO DE ASSIS, Joaquim Maria. Memórias póstumas de Brás Cubas. São Paulo: Ateliê Editorial, 2001.

MANN, Thomas. "Dostoiévski, com moderação". In: MANN, Thomas. O escritor e sua missão: Goethe, Dostoiévski, Ibsen e outros. Rio de Janeiro: Zahar, 2011, p. 113-33.

MERSEREAU JR., John. "The Nineteenth Century: Romantism, 1820-40". In: MOSER, Charles A. The Cambridge History of Russian Literature. Cambridge: Cambridge University Press, 1992. p. 136-88.

MEYER, Augusto. "Sempre Dostoiévski". In: BARBOSA, João Alexandre (org.). Textos críticos. São Paulo: Perspectiva, 1986, p. 373-84.

"Sempre Dostoiévski”. In: MEYER, Augusto. Ensaios escolhidos. Rio de Janeiro: José Olympio, 2007, p. 110-28.

MILNER-GULLAND, Robin. "Old Russian Literature and Its Heritage". In: CORNWELL, Neil. The Routledge Companion to Russian Literature. New York: Routledge, 2001, p. 1225.

MONTAIGNE, Michel de. Ensaios. São Paulo: Companhia das Letras/Penguin, 2010.

NIETZSCHE, Friedrich. A gaia ciência. São Paulo: Companhia das Letras, 2012.

OGDEN, Daniel. A Companion to Greek Religion. West Sussex: Wiley-Blackwell, 2010.

PAPERNO, Irina. Suicide as a Cultural Institution in Dostoevsky's Russia. Ithaca: Cornell University Press, 1997.

PAREYSON, Luigi. Dostoiévski: Filosofia, romance e experiência religiosa. São Paulo: Editora da Universidade de São Paulo, 2012.

PEACE, Richard. "The Nineteenth Century: The Natural School and Its Aftermath, 1840-55". In: MOSER, Charles A. The Cambridge History of Russian Literature. Cambridge: Cambridge University Press, 1992, p. 189-247.

PEREIRA, Ana. "O demônio moderno". In: CAVALIERE, A.; GOMIDE, B.; SILVA, N.; VÁSSINA, E. (orgs.). Caderno de literatura e cultura russa. $n^{\circ}$ 2, Cotia: Ateliê Editorial, 2008.

PLATÃO. Fédon. Brasília: Editora Universidade de Brasília, 2000. 
PONDÉ, Luís Felipe. Crítica e profecia: A filosofia da religião em Dostoiévski. São Paulo: editora 34, 2003.

PUENTE, Fernando. Os filósofos e o suicídio. Belo Horizonte: Editora da Universidade Federal de Minas Gerais, 2008.

RABELAIS, François. Gargântua e Pantagruel. Belo Horizonte; Rio de Janeiro: Villa Rica, 1991, 2 v.

SARTRE, Jean-Paul. O ser e o nada. Petrópolis: Vozes, 2005.

SCHNAIDERMAN, Boris. Dostoiévski: Prosa e poesia. O senhor Prokhartchin. São Paulo: Perspectiva, 1982.

"Prefácio". In: PÚCHKIN, Aleksandr. A dama de espadas: Prosa e poesia. São Paulo: editora 34, 1999, p. 7-15.

SCHWARZ, Roberto. Um mestre na periferia do capitalismo: Machado de Assis. São Paulo: Duas Cidades, 1990.

SCIACCA, Michele Federico. Morte e imortalidade. São Paulo: É Realizações, 2011.

SERMAN, Ilya. "The Eighteenth Century: Neoclassicism and the Enlightenment, 1730-90". In: MOSER, Charles A. The Cambridge History of Russian Literature. Cambridge: Cambridge University Press, 1992. p. 45-91.

SHAKESPEARE, William. Hamlet e Macbeth. Rio de Janeiro: Nova Fronteira, 1995.

SHNEIDMAN, N. N. Dostoevsky and suicide. Oakville: Mosais Press, 1984.

SOLOMON, Andrew. O demônio do meio-dia: Uma anatomia da depressão. São Paulo: Companhia das Letras, 2014.

STONE, I. F. O julgamento de Sócrates. São Paulo: Companhia das Letras, 2005.

TREVOR, Douglas. The Poetics of Melancholy in Early England. Cambridge: Cambridge University Press, 2004.

VENEU, Marcos. Ou não ser: Uma introdução à história do suicídio no Ocidente. Brasília, Editora da Universidade de Brasília, 1994.

VOGÜÉ, Melchior de. O romance russo. Rio de Janeiro: A Noite, 1949.

WEINER, Adam. By Authors Possessed: The Demonic Novel in Russia. Evanston: Northwestern University Press, 1998.

\section{INTERNET}

SILVA JR., Augusto Rodrigues da. Tanatografias e decomposições biográficas: discurso da morte na literatura. Disponível em http://www.anpoll.org.br/revista/ index.php/revista/article/view/185/197. Acessado em 03 de junho de 2013.

Morte e decomposição biográfica em Memórias póstumas de Brás Cubas. Tese de doutorado. Universidade Federal Fluminense, 2008. Disponível em: http://www.livrosgratis.com.br/arquivos_livros/cp074719.pdf. Acessado em 10 de julho de 2014.

Morte saturnal e tanatografia em François Rabelais. Revista Moara (Impresso), $\mathrm{n}^{\circ}$ 37, jan.-jun., Estudos Literários, 2012. Disponível em: <http://www.periodicos.ufpa.br/index.php/moara/article/viewFile/1359/1794>. Acesso em: fevereiro de 2014. 